San Jose State University

SJSU ScholarWorks

Spring 2020

\title{
The Role of Socioeconomic Status and Prior Industry Exposure on the Attitudes, Career Goals, and Career Decision Self-Efficacy of Undergraduates Studying Hospitality and Tourism Management
}

Laura McKenzie Shroder

San Jose State University

Follow this and additional works at: https://scholarworks.sjsu.edu/etd_dissertations

\section{Recommended Citation}

Shroder, Laura McKenzie, "The Role of Socioeconomic Status and Prior Industry Exposure on the Attitudes, Career Goals, and Career Decision Self-Efficacy of Undergraduates Studying Hospitality and Tourism Management" (2020). Dissertations. 41.

DOI: https://doi.org/10.31979/etd.ua2h-25jk

https://scholarworks.sjsu.edu/etd_dissertations/41

This Dissertation is brought to you for free and open access by the Master's Theses and Graduate Research at SJSU ScholarWorks. It has been accepted for inclusion in Dissertations by an authorized administrator of SJSU ScholarWorks. For more information, please contact scholarworks@sjsu.edu. 


\title{
THE ROLE OF SOCIOECONOMIC STATUS AND PRIOR INDUSTRY EXPOSURE ON THE ATTITUDES, CAREER GOALS, AND CAREER DECISION SELF- EFFICACY OF UNDERGRADUATES STUDYING HOSPITALITY AND TOURISM MANAGEMENT
}

\author{
A Dissertation \\ Presented to \\ San José State University \\ In Partial Fulfillment \\ of the Requirements for the Degree \\ Doctor of Education
}

The Faculty of the Educational Doctoral Program in Educational Leadership

by

Laura McKenzie Shroder

May 2020 
(C) 2020

Laura McKenzie Shroder ALL RIGHTS RESERVED 
The Designated Dissertation Committee Approves the Dissertation Titled

THE ROLE OF SOCIOECONOMIC STATUS AND PRIOR INDUSTRY EXPOSURE ON THE ATTITUDES, CAREER GOALS, AND CAREER DECISION SELFEFFICACY OF UNDERGRADUATES STUDYING HOSPITALITY AND TOURISM MANAGEMENT

by

Laura McKenzie Shroder

\section{APPROVED FOR THE EDUCATIONAL DOCTORAL PROGRAM IN EDUCATIONAL LEADERSHIP}

SAN JOSÉ STATE UNIVERSITY

MAY 2020

Paul W. Cascella, Ph.D.

Robin Love, Ph.D.

Andrew H. Feinstein, Ph.D.

Susan Roe, Ph.D.
Professor, Department of Communicative Disorders and Sciences

Associate Professor, Department of Child and Adolescent Development

President, University of Northern Colorado

Associate Professor, Department of Hospitality and Tourism Management, San Francisco State University 


\begin{abstract}
THE ROLE OF SOCIOECONOMIC STATUS AND PRIOR INDUSTRY EXPOSURE ON THE ATTITUDES, CAREER GOALS, AND CAREER DECISION SELFEFFICACY OF UNDERGRADUATES STUDYING HOSPITALITY AND TOURISM MANAGEMENT
\end{abstract}

by Laura McKenzie Shroder

The hospitality and tourism industry struggles with high employee turnover, and many hospitality management students graduate and subsequently leave or choose not to enter the industry. Scholars have found it beneficial to study students' industry attitudes, career goals, demographics, and career decision self-efficacy to further understand how these variables influence students' perceptions, engagement, and retention. This quantitative study measured these variables as well as prior industry exposure, which is based on the Social Cognitive Career Theory. Results of an online survey of hospitality students in the Western United States ( $n=315$; response rate $79.9 \%)$ suggested that students' prior industry exposure was a factor in self-efficacy and attitudes. Results also indicated that elements of students' socioeconomic status and race were factors in students' attitudes, self-efficacy, and industry exposure. Recommendations were offered regarding how hospitality management programs can fine-tune their curricula, professional development, and career services programing based on the demographics of their students. Recommendations also included increasing partnerships between universities and industry recruiters to benefit students as they transition into professional roles and to maximize recruitment and retention efforts. 


\section{ACKNOWLEDGMENTS}

This took a village. First, I would like to thank my advisor, Dr. Paul Cascella. Thank you for taking a chance on someone from a different subject matter but seeing the potential we had as an exceptional team. Your endless post-it notes, and consistent meetings kept me focused, motived and excited to continue the process. You made this experience enjoyable and rewarding and I could not have asked for a more talented and caring mentor. I would also like to thank my other committee members, Dr. Love and Dr. Feinstein, for their insight, mentoring, and expertise. Finally, Dr. Susan Roe, has been my professional mentor since I started working in education. Dr. Roe was a guiding force in pursuing my doctoral studies. Thank you for seeing my potential and allowing me to recognize it. I admire you as a professional, educator, and mentor. I would also like to thank the faculty of the Ed.D. program at San Jose State University. I am grateful for the opportunities and the ability to learn from exceptional scholars. Thank you to Haozhen Shu for her statistics support and to "C4". The richness everyone brought to the classroom helped me learn and grow. I would also like to thank my students whose stories and passion encouraged me to be a better educator, mentor, and advocate. I would like to thank Pouya, Mom, and Dad who balanced crazy schedules while Pouya and I obtained graduate degrees. Thank you for your consistent support and love. We certainly sacrificed and I'm proud of what we have accomplished. To my son, Chase, who made me more determined and motivated me to be better. Finally, to my lifelong proofreader and sounding board, Mom, I could not have done this without you and this dissertation is dedicated to you. It took a village and mine was unparalleled. 


\section{TABLE OF CONTENTS}

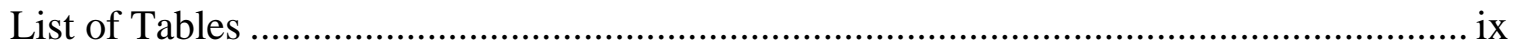

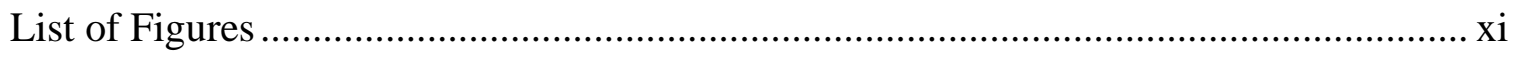

Chapter 1. Introduction and Statement of the Problem..................................................... 1

Hospitality and Tourism Industry Turnover ............................................................. 1

Pre-Professional Student Perspectives .................................................................... 3

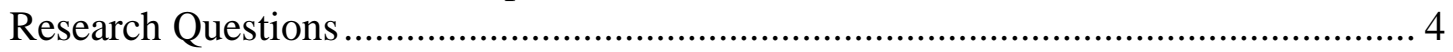

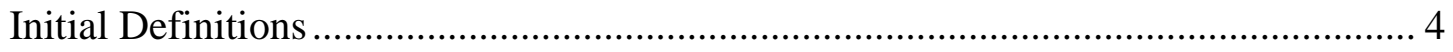

Chapter 2. Review of the Literature............................................................................. 7

The Study of Hospitality and Tourism Management Students ..................................... 7

Reasons Why Students Study Hospitality and Tourism Management ......................... 8

Variables that influence selecting hospitality and tourism management................ 9

Influence of work experience and internships. ................................................... 10

Intention to enter the hospitality and tourism industry........................................ 12

Negative Hospitality and Tourism Industry Attitudes and Perceptions....................... 14

Differences Based on Student Variables.............................................................. 16

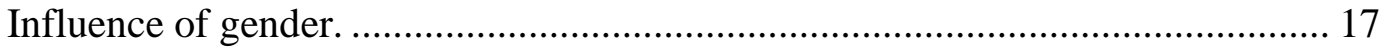

Influence in the level of schooling.................................................................. 18

Differences based on country of residence. .......................................................... 19

Influence of chosen study emphasis in the hospitality industry. .......................... 23

Influence of family socioeconomic status for hospitality students........................ 23

Lack of research regarding hospitality students' SES. ........................................ 25

Profile of General Students from a Low Socioeconomic Status.................................. 26

Stressors associated with low income................................................................ 28

Gender influences versus socioeconomic status on major selection. .................... 29

Interaction of race and ethnicity and socioeconomic status................................... 29

Theoretical Framework: The Social Cognitive Career Theory ..................................... 31

Site Selection and Sample..................................................................................... 6

Low socioeconomic status and characteristics of travel and tourism.................. 33

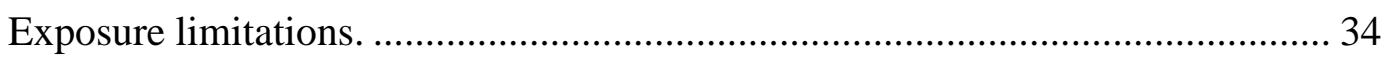

Social justice in career services. ....................................................................... 36

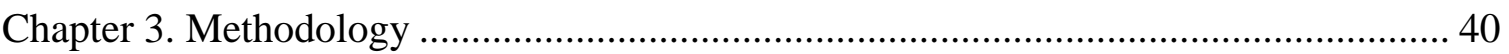

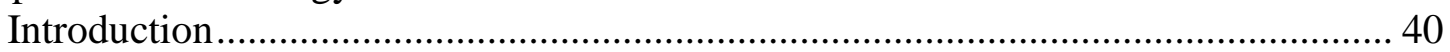

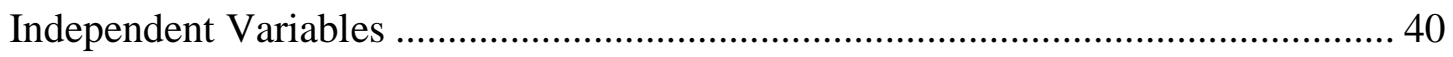

Measuring socioeconomic status and parental education. .................................... 40

Income via Pell grant status. .......................................................................... 42

Measuring prior industry exposure: tool development. ....................................... 43

Prior industry exposure assessment research design and instrument validity. ..... 47

Defining year in school................................................................................. 48 


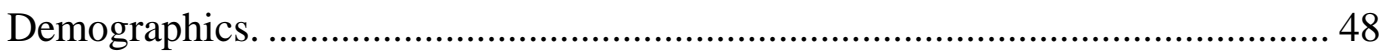

Dependent Variables ........................................................................................ 49

Measuring attitudes and career goals.......................................................... 49

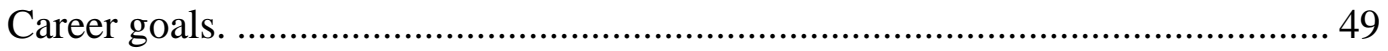

Industry attitude and career goals: tool reliability and validity........................... 50

Measuring career decision self-efficacy (CDSE). …………............................. 52

Career Decision Self-Efficacy-SF tool reliability and validity............................ 52

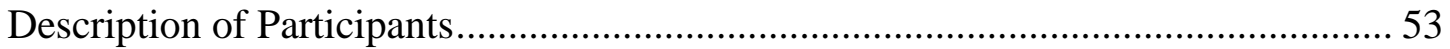

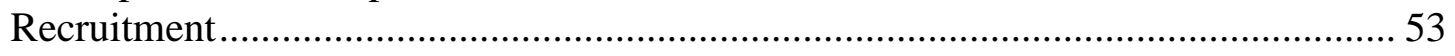

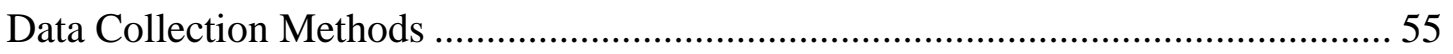

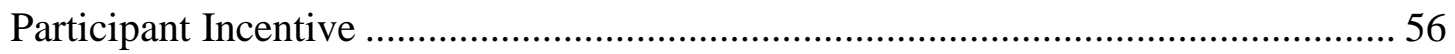

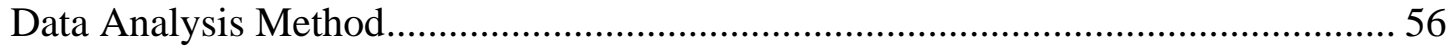

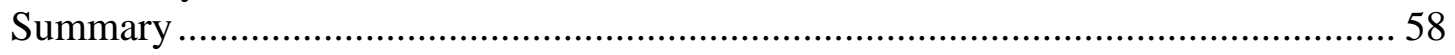

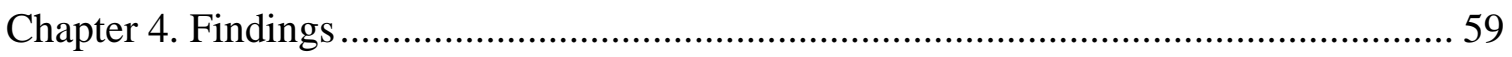

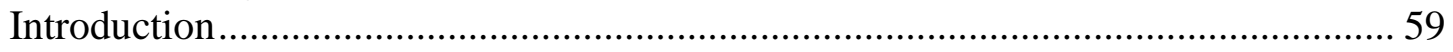

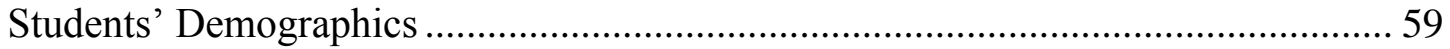

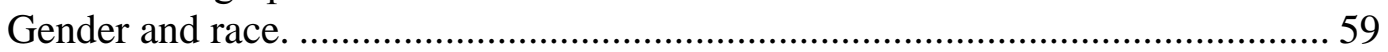

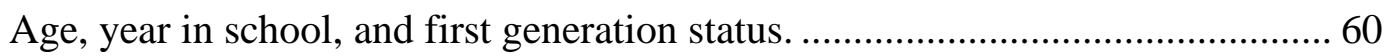

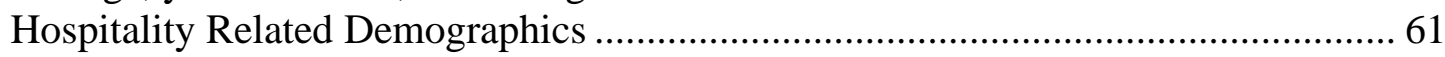

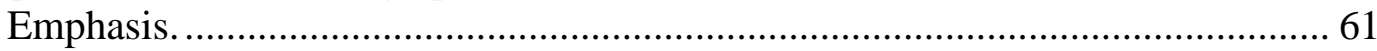

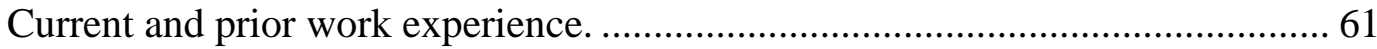

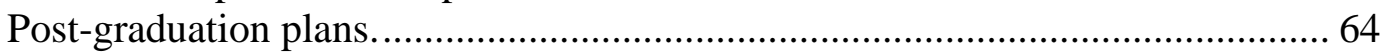

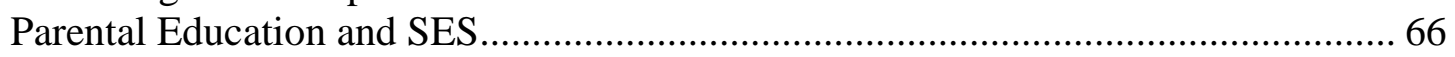

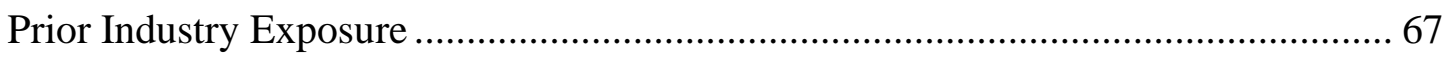

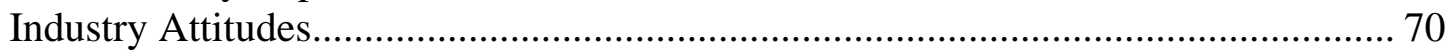

Career Decision Self-Efficacy ......................................................................... 71

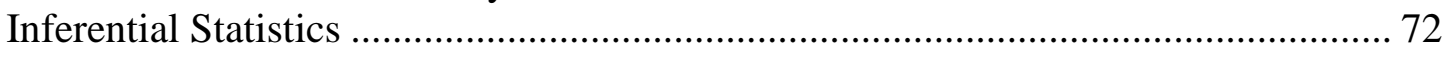

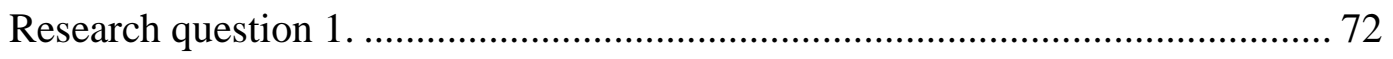

Socioeconomic status and industry attitudes. ......................................... 72

Socioeconomic status and career goals................................................... 72

Socioeconomic status and career decision self-efficacy........................... 72

Post hoc analysis of the SES definition. ................................................. 73

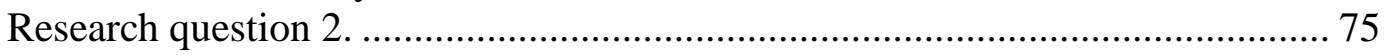

Prior industry exposure and career goals............................................... 75

Prior industry exposure and career decision self-efficacy........................ 75

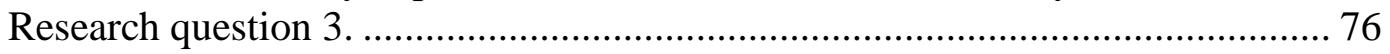

Year in school and industry attitudes, career goals, and career decision

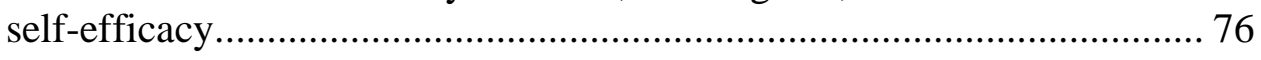

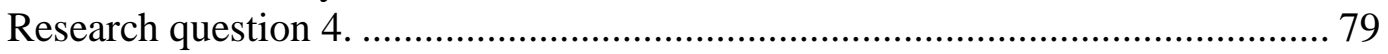

Demographics characteristics related to industry attitudes....................... 79

Additional post-hoc analysis related to demographic variables. ................ 79

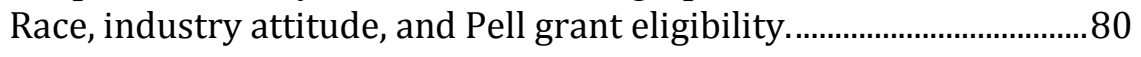




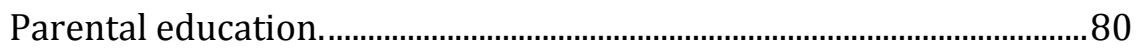

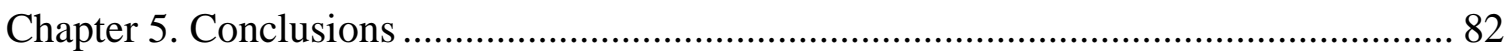

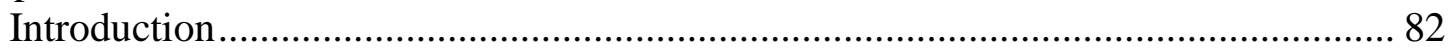

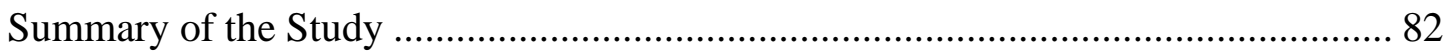

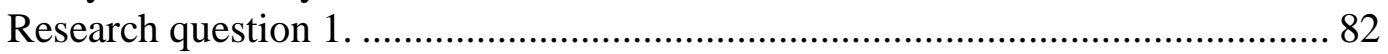

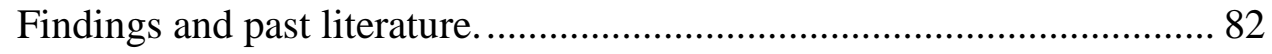

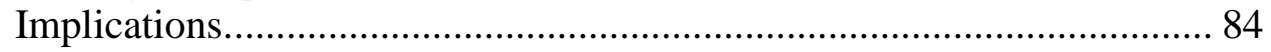

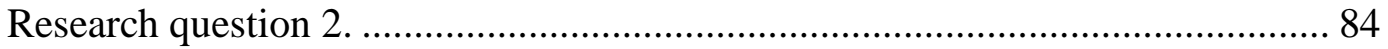

Findings and past literature......................................................... 84

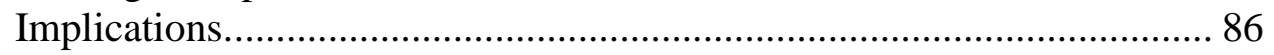

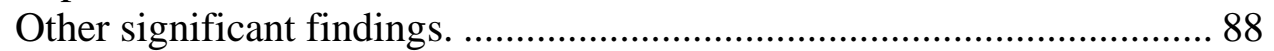

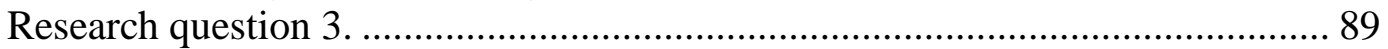

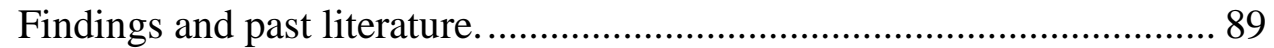

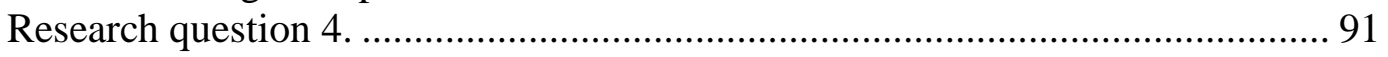

Findings and past literature........................................................ 91

Sex.

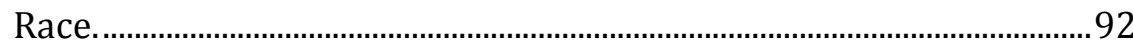

Age

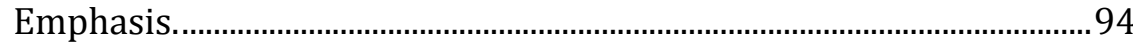

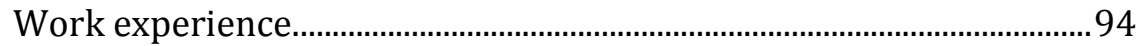

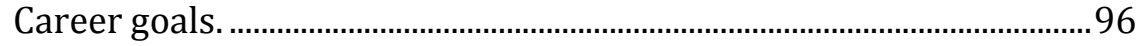

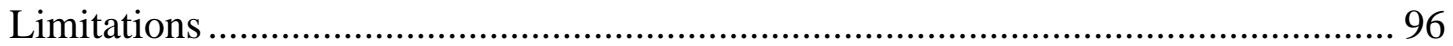

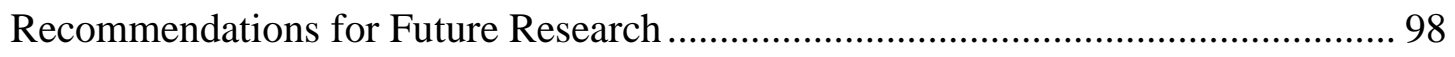

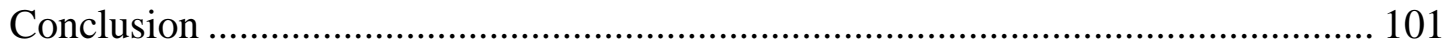

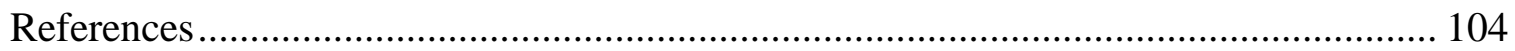

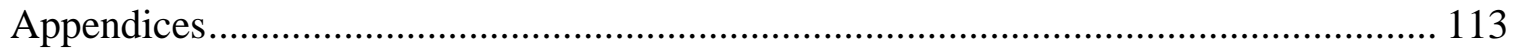

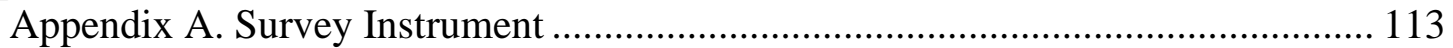

Appendix B. Faculty Emails .................................................................................. 139

Appendix C. Focus Group Guide and Student Profiles .......................................... 141

Appendix D. IRB Notice of Approval ............................................................ 147

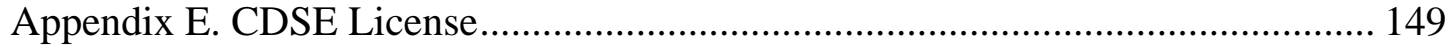




\section{LIST OF TABLES}

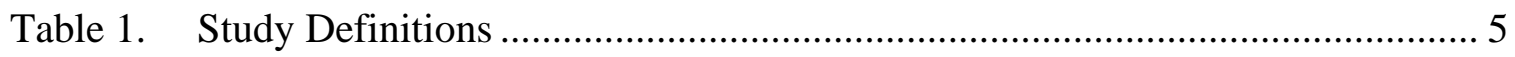

Table 2. Measures of Socioeconomic Status in Prior Research by Studies ................. 41

Table 3. Quantifying Extensive Exposure HTM Activities ....................................... 46

Table 4. Kusluvan and Kusluvan's (2000) Scale Reliability by Sub-Category ........... 51

Table 5. Proposed Statistics by Research Question ............................................. 57

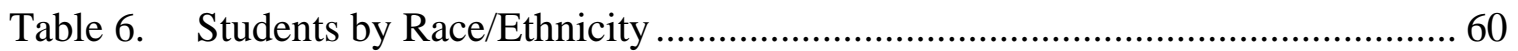

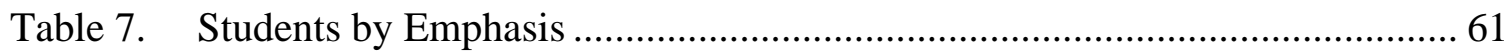

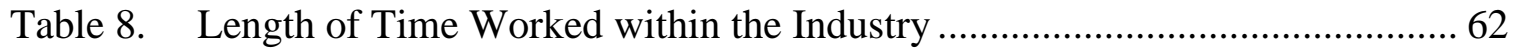

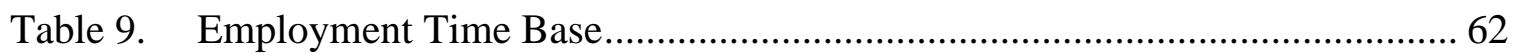

Table 10. Average Number of Hours Worked in a Week.......................................... 63

Table 11. Time Worked as a Group Percentage by SES Status.................................. 63

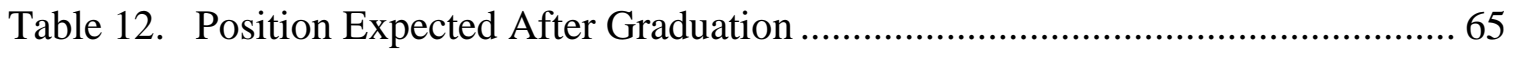

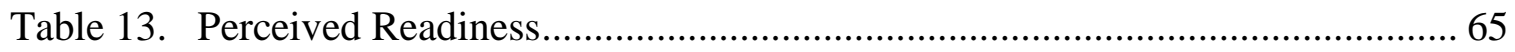

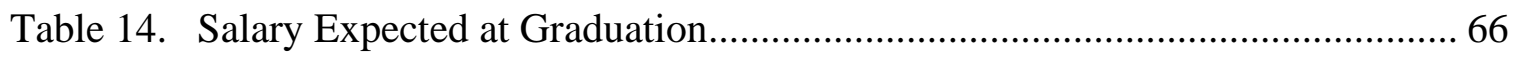

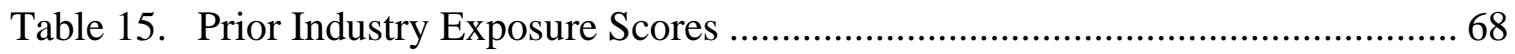

Table 16. Student Prior Industry Exposure Participation by Activity .......................... 69

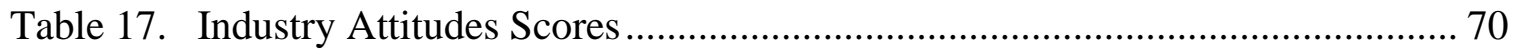

Table 18. Individual Question Assessment Scores ............................................... 71

Table 19. Career Decision Self-Efficacy Scores ................................................. 71

Table 20. Pell Eligible: Industry Attitudes vs. Parents' Education............................... 73

Table 21. Parents' High Education: Industry Attitudes vs. Pell Eligibility ................... 74 
Table 22. Pell Eligibility: Career Goals vs. Parents' Education .................................. 74

Table 23. Parents' High Education: Career Goals vs. Pell Eligibility ........................... 74

Table 24. Freshman Findings: Dependent Variables' Pearson Correlations .................. 77

Table 25. Sophomore Findings: Dependent Variables' Pearson Correlations................ 77

Table 26. Junior Findings: Dependent Variables' Pearson Correlations ....................... 78

Table 27. Senior Findings Dependent Variables' Pearson Correlations........................ 78

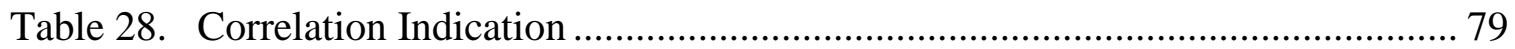




\section{LIST OF FIGURES}

Figure 1. Vocation interest development in hospitality. ....................................... 33

Figure 2. Prior industry exposure tool development ......................................... 43

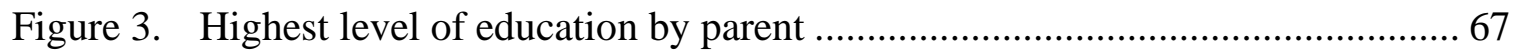




\section{Chapter 1. Introduction and Statement of the Problem}

The United States Department of Labor categorizes the Leisure and Hospitality industry with two subsectors: 1) Arts, Entertainment, and Recreation, and 2) Accommodations and Food Services. According to one of their most recent reports titled “Employment by Major Industry Sector", produced by the United States Department of Labor (2017), Bureau of Labor Statistics, employment in the Leisure and Hospitality industry is expected to continually increase. It is projected that Leisure and Hospitality jobs will increase from $13,109,000$, as recorded in 2006 , to $16,939,000$ jobs in 2026 . The industry will be adding 3,839,000 jobs from 2006 to 2026. Job growth and dollar output in the Leisure and Hospitality sector is significant. In the United States, the hospitality industry has experienced consistent employment growth for ten years and is currently facing the largest employment gap of any industry (Tall, 2019). The increase of projected jobs, along with the current employment gap for the industry, make it essential to have a skilled and trained future workforce ready to enter these positions.

\section{Hospitality and Tourism Industry Turnover}

The hospitality industry experiences heavy turnover in both line level and managerial positions (Ghiselli, La Lopa, \& Bai, 2001; Self, Gordon, \& Ghosh, 2020). The increase in jobs projected by the Bureau of Labor Statistics, paired with industry turnover, give universities with four-year hospitality and tourism management programs (HTM) the task of recruiting, retaining, and producing future professionals to fill these increasingly vacant managerial roles. Yet, many students who study HTM (which includes the segments of the industry as defined by the federal term Leisure and Hospitality) leave the 
industry shortly after graduation (Kusluvan \& Kusluvan, 2000; Li, 2011; Self et al., 2020). Other HTM students graduate with a degree and have no intention of working in the industry (Richardson, 2008). The increase in the number of projected jobs and the existing high industry turnover rate create a large surplus of jobs in the industry compared to the number of qualified hospitality professionals (Grobelna, 2017). The industry is having a difficult time recruiting four-year degreed HTM graduates and then retaining them for a long period of time. These issues suggest that the industry is not meeting the students' needs and expectations for a career in the hospitality industry (Grobelna, 2017). HTM students who are graduating with the theoretical background, as well as the hands-on work experience in the industry, are valuable and a desirable resource for the future of the industry (Richardson \& Butler, 2012).

For many hospitality companies, losing new hires to other sectors comes with high financial and psychological costs. Davidson, Timo, and Wang (2010) estimated the cost of replacing an operational or line-level employee is around $\$ 6,349$ while replacing an executive, manager, or supervisor is around $\$ 72,763$. Financial implications include the cost of recruitment, hiring, and training processes (Davidson et al., 2010; Mohd Zahari, 2004), whereas the psychological implications include a decrease in employee morale when young graduates leave the industry (Richardson \& Butler, 2012). Further, the loss of newer hires could affect customer loyalty and customer satisfaction (Richardson, 2008) since relationships and interactions with employees are linked to customer retention. Decreased customer retention negatively impacts a company's revenue and 
thus, employees are one critical factor in establishing a company's competitive advantage (Richardson, 2008).

\section{Pre-Professional Student Perspectives}

Students who are studying HTM gain the knowledge and professional skills that are needed in the industry (Kusluvan \& Kusluvan, 2000; Quinn \& Buzzetto-Hollywood, 2019; Richardson, 2008; Richardson \& Butler, 2012). The expected increase in jobs and high turnover in the hospitality industry make it imperative to fully understand students' attitudes about the hospitality industry and their expectations for an HTM career. Further research on student HTM perceptions and attitudes is needed to provide the industry with insight into their future employees and the demands that they will express (Lu \& Adler, 2008). If employers do not understand and adapt to their potential employees' attitudes, the result could be early turnover and the inability to recruit and retain skilled professionals (Mohd Zahari, 2004). Knowledge of future employees' attitudes and career expectations can be used as a recruitment tool for hospitality companies to ensure their alignment with future employees' expectations. Moreover, universities can use students' industry attitudes and career expectations as tools for revising higher education programing in order to meet student expectations (Stone, Padron, Wray, \& Olson, 2017) thus retaining them in the HTM major and enhancing potential employee-employer relationships. Understanding students' attitudes about the hospitality industry can also aid universities and students in providing tailored advising and career services programing. These services support students with regards to time to graduation and identifying a rewarding career post-graduation. Both stakeholders, the hospitality industry and HTM 
educational programs, are vital partners to reduce the shortage of skilled hospitality professionals.

\section{Research Questions}

The objectives of this study were operationalized into the following research questions broadly framed under the goal of identifying the industry attitudes, career goals, and career decision self-efficacy of contemporary HTM students. Specifically, as described and justified in chapter 2, this study had four Research Questions (RQ):

RQ 1: How does socioeconomic status affect HTM students' a) industry attitudes, b) career goals, and c) career decision self-efficacy?

RQ 2: How does prior industry exposure affect HTM students' a) industry attitudes, b) career goals, and c) career decision self-efficacy?

RQ 3: How does year in school affect HTM students' a) industry attitudes, b) career goals, and c) career decision self-efficacy?

RQ 4: What is the relationship between HTM students' demographic characteristics and their a) industry attitudes, b) career goals, and c) career decision selfefficacy?

\section{Initial Definitions}

Table 1 offers terms and definitions to ensure consistency throughout this study. 


\section{Table 1}

\section{Study Definitions}

\begin{tabular}{|c|c|}
\hline Key Terms & Definitions \\
\hline Industry Attitudes & $\begin{array}{l}\text { "The total of all cognitive thoughts, feelings, and behavioral tendencies students } \\
\text { have about the different aspects or dimensions of working in the tourism } \\
\text { industry, as well as the work intentions in, or commitment to, the industry" } \\
\text { (Kusluvan and Kusluvan, 2000, p.254). }\end{array}$ \\
\hline Career & $\begin{array}{l}\text { The unfolding sequence of a person's work experiences over time (Richardson } \\
\& \text { Butler, 2012). }\end{array}$ \\
\hline $\begin{array}{l}\text { Career decision self-efficacy } \\
\text { (CDSE) }\end{array}$ & $\begin{array}{l}\text { The degree of confidence in one's ability to successfully make career decisions } \\
\text { (Betz, Klein, \& Taylor, 1996) }\end{array}$ \\
\hline Emphasis & $\begin{array}{l}\text { The specific curriculum or work experience HTM segment a student chooses to } \\
\text { explore i.e., hotel management, food and beverage management, event } \\
\text { management, private club management, airline management. }\end{array}$ \\
\hline Hospitality industry & $\begin{array}{l}\text { Includes food, lodging, recreation, and travel-related services (Barrows \& } \\
\text { Bosselman, 1999). }\end{array}$ \\
\hline $\begin{array}{l}\text { Hospitality and tourism } \\
\text { management programs }\end{array}$ & $\begin{array}{l}\text { Four-year Bachelor's degree programs devoted to preparing students for } \\
\text { hospitality management positions. This could be a college, department, or } \\
\text { emphasis area. }\end{array}$ \\
\hline HTM & An acronym for hospitality and tourism management. \\
\hline Industry & Refers to the hospitality industry. \\
\hline Leisure & $\begin{array}{l}\text { Sector of the hospitality industry that includes Arts, Entertainment, and } \\
\text { Recreation. }\end{array}$ \\
\hline Line-level & Employees whose jobs are considered entry level or nonsupervisory \\
\hline Management role & $\begin{array}{l}\text { The functions of planning, organizing, controlling, and leading within the } \\
\text { hospitality industry (Brymer, 2003). }\end{array}$ \\
\hline Social justice & $\begin{array}{l}\text { Actions that contribute to the advancement of society and advocate for equal } \\
\text { access to resources for marginalized or less fortunate individuals. (O'Brien, } \\
\text { 2001). }\end{array}$ \\
\hline Socioeconomic status (SES) & $\begin{array}{l}\text { The social standing or class of an individual or group; often measured as a } \\
\text { combination of education, income and occupation (American Psychological } \\
\text { Association, n.d.). }\end{array}$ \\
\hline Underrepresented population & For this study, refers to individuals from lower socioeconomic backgrounds. \\
\hline
\end{tabular}




\section{Site Selection and Sample}

This study focused on four-year bachelor's degree undergraduate students who were at least 18 years of age and had declared HTM as their major. Students from eleven, predominantly western, state universities with hospitality programs were surveyed. 


\section{Chapter 2. Review of the Literature}

This chapter provides a description of the extant literature and theoretical framework for this study in support of the following research questions: How do socioeconomic status, prior industry exposure, year in school, and demographics affect HTM students' industry attitudes, career goals, and career decision self-efficacy? The chapter will begin with a discussion of why students select HTM as a major and the factors that influence their decision. Second, negative perceptions about the hospitality industry are explored, including the identification of variables that affect students' attitudes and perceptions of the hospitality industry. Next, a review of the literature explores how students' socioeconomic status affects their views of the industry and identifies gaps in the literature. Finally, the framework of the Social Cognitive Career Theory will be explored followed by literature regarding student exposure.

\section{The Study of Hospitality and Tourism Management Students}

The ongoing need for a hospitality labor force in the United States drove the creation of hospitality and tourism programs (Formica, 1996). The two most popular types of hospitality degrees offered in the United States are Associate degrees and Bachelor degrees (Formica, 1996). Associate degrees focus on technical attributes that prepare students for line-level positions at graduation. Bachelor degrees focus on problemsolving and managerial competencies to develop future managers within the hospitality industry (Formica, 1996). For the purpose of this study, the subjects were students, within a four-year bachelor's degree program, studying to become managers within the hospitality industry. 
With the increase in hospitality jobs, continued projected growth, and heavy turnover experienced by recent HTM graduates (Kusluvan \& Kusluvan, 2000; Li, 2011; Self et al., 2020, United States Bureau of Labor Statistics, 2020), it is essential to examine and understand the reasons and motives of students studying HTM. As an introduction, it is important to note that there are myriad studies of HTM students, and the accompanying research topics are diverse and encompassing. As related to this paper's topics, for example, many scholars have explored HTM students' perceptions of the hospitality industry (Grobelna, 2017; Lee, Kim, \& Lo, 2008; Richardson, 2008; Richardson, 2009), career choice and career goals (Korir \& Wafula, 2012; Lu \& Adler, 2009; Qiu, Dooley, \& Palkar, 2017), different educational levels (e.g., year in school) (O'Mahony, McWilliams, \& Whitelaw, 2001), and their intentions to join the industry (Walsh, Change, \& Tse, 2015). All of the studies contribute to the overall body of literature identifying why students choose HTM as a major and/or their potential career aspirations. In contrast, research is lacking in understanding how students' socioeconomic status and prior industry exposure affect their industry attitudes and career goals. Understanding how these variables interact will help the industry and universities with recruitment and retention. This knowledge will also support efforts in meeting the career expectations of HTM graduates, thus reducing high industry turnover.

\section{Reasons Why Students Study Hospitality and Tourism Management}

There are many reasons why students choose HTM as a major and future career choice, and this topic has been widely researched (e.g., Chan, 2017; Chuang, Goh, Stout, \& Dellmann-Jenkins, 2007; Grobelna, 2017; Lu \& Adler, 2008; Richardson \& Butler, 
2012; Richardson, 2008). Some studies found that the job opportunities and the projected growth of the industry motivated students to select HTM as a major and career choice (Gitau, 2016; Korir \& Wafula, 2012; Lee et al., 2008; Lu \& Adler, 2008; O’Mahony et al., 2001; Richardson, 2008). Additionally, the opportunities for advancement and career development prospects attracted students to the hospitality industry (Grobelna, 2018; Korir \& Wafula, 2012; Lu \& Adler, 2008). Students perceived working in the hospitality industry as challenging yet interesting and enjoyable work (Akin Aksu \& Deniz Köksa, 2005; Blomme, Van Rheede, \& Tromp, 2009; Chan, 2017; Grobelna, 2018; Kusluvan \& Kusluvan, 2000; Richardson \& Butler, 2012). Other reasons included: the opportunity to work with people (Chuang \& Dellmann-Jenkins, 2010; Hjalager, 2003), including persons from different cultures and nationalities (Chan, 2017; Lu \& Adler, 2008); the personal opportunity to travel (Richardson, 2008) and the ability to work abroad (Akin Aksu \& Deniz Köksa, 2005); and a passion for the industry (Chuang \& DellmannJenkins, 2010), and a positive perception about the field's attractiveness (Lee et al., 2008).

\section{Variables that influence selecting hospitality and tourism management.}

Researchers have reported mixed findings when analyzing what influences selection of HTM as a major and career choice. One study (Korir \& Wafula, 2012) noted the influence of job opportunities, external influencers (such as personal network) and program advertisements influenced students to study hospitality rather than students' personal factors including gender, GPA from grade school, and perceived lifestyle of those employed in the industry. Other studies showed the importance of teachers' 
friendliness (Dodds \& Muchnick, 2008) and availability (O’Mahony et al., 2001), and the influence of family support and conversations with classmates (Qiu et al., 2017). Additional influences included current employment status and career expectations (Chuang et al., 2007). Two studies (Korir \& Wafula, 2012; Qiu et al., 2017) found that students' ability to have their own choice in selecting a major and career decision was a factor in choosing to study HTM.

In contrast, Korir and Wafula (2012) discovered that students did not consider family tradition as an influence of their career, and only half of the respondents agreed that they were influenced by people around them. Similar conclusions were drawn by Dodds and Muchnick (2008) who found that most students were not influenced by their family or friends when selecting a major. Korir and Wafula's (2012) study showed that most respondents disagreed that personal factors such as family, gender, grades and income influenced their decision to work in the hospitality industry. Additionally, respondents did not find job placement or job shadowing influential and were more affected by the technical schools they attended (Korir \& Wafula, 2012). These differing results surrounding why students chose HTM as a major and career choice suggest that future research needs to be conducted to fully understand the myriad potential reasons for the conflicting results.

Influence of work experience and internships. Kim, McCleary and Kaufman (2010) found that perhaps the most important influence in selecting the hospitality industry as a career choice was industry work experience and students' personal interactions within the industry. Industry experience played a significant role in students' 
intent to enter the industry after graduation (Chen \& Shen, 2012; Chuang \& DellmannJenkins, 2010; Gitau, 2016; Richards, 2008). This idea suggests that if students are given high quality experiences and internships, they will gain a positive perspective of the industry (Gitau, 2016; Richardson, 2008; Richardson \& Thomas, 2012), hopefully leading to realistic expectations and increased retention in the hospitality industry (Chuang, et al., 2007; Stone et al., 2017).

Gitau (2016) examined the influence of internships on hospitality students' career decisions. He analyzed gender, age, and background and concluded that although gender, geographical location, and personal backgrounds influence career decision, the strongest predictor of retention in the industry was a positive internship experience. Internships gave students a realistic expectation of the industry (Gitau, 2016). Other studies (Chan, 2017; Chuang \& Dellmann-Jenkins, 2010) similarly found that students were positively influenced by their pre-professional experience working in the industry. Chen and Chen (2011) noted that positive experiences with an internship helped students increase their interpersonal skills, understand their future work environments, and gain professional insight that was not taught at school. Like Gitau's (2016) finding, Chen and Chen (2011) also concluded that a positive internship experience was the greatest factor in student industry work intent. Conversely, in a related industry, Ahmad, Ismail, and Anantharaman (2015) examined the effects of an internship on career intention with accounting students. Results indicated that the internship experience was not a significant variable in student work intention within the accounting industry. Hart, Kremin, and Pasewark (2016) found that students who participated in a public accounting internship 
experienced a decrease in intention-to-work in the industry. This finding was attributed to students' quick exposure to the realities of the position.

The time length and nature of an internship in the hospitality industry were also an influence. Longer duration internships resulted in an increased likelihood that students were interested in entering the industry after graduation (Gitau, 2016). Additionally, the nature of the internship held importance. Students who interned in only one department had greater intentions of entering the industry compared to those in rotational internships (Gitau, 2016). High quality work experience and internships remained large influencers on students' intentions to enter the industry (Chen \& Shen, 2012). A positive internship experience was the strongest predictor of industry intent (Chen \& Shen, 2012; Gitau, 2016). Students who had these experiences gained the industry skills needed for success and were more committed to pursuing a career in the hospitality industry (Chuang, et al., 2007).

The findings regarding internships and the effects on students' intent to enter the industry are mixed. Due to this reason, the present study will also examine students' work experience, length of experience, type of experience, and how work experience influenced students' intention to work in the hospitality industry.

Intention to enter the hospitality and tourism industry. There are many factors that graduating hospitality students consider when pursing employment. Opportunities for personal development and salary were important aspects that students considered (Lu \& Adler, 2008). Interestingly, students ranked professional learning and development opportunities as a greater influence than salary (Lu \& Adler, 2008). 
Perhaps the most concerning research findings regarding HTM students' intent to enter the industry were inconsistencies regarding the percentage of students who intended to work in the industry. Gitau (2016) found one of the highest percentages and noted that $85 \%$ of respondents were seeking a job in the industry after graduation. Another study (Chuang, et al., 2007) found $82 \%$ of their respondents had intended to work in the industry after graduation. Chan (2017) discovered that 73\% of respondents, while Lu and Adler (2008) noted 68\%, and Richardson (2008) found that less than 27\% of respondents would definitely pursue the hospitality industry as a career. Comparatively, another service profession with workforce shortages is the teaching profession (Struyven \& Vanthournout, 2014). Struyven and Vanthournout (2014) found that $77 \%$ of the respondents worked as a teacher after graduating, while $33 \%$ of respondents never entered the profession.

Chan (2017) found that first-year college hospitality students had the strongest desire (82\%) to pursue work in the hospitality industry compared to third-year college students (65\%). Blomme, Van Rheede, and Tromp (2009) discovered that only 67\% of first-year college students agreed that they genuinely wanted to work in the industry, compared to $80 \%$ of graduates. As demonstrated, the intent of students to enter the hospitality industry differed with each study. Regardless of the percentage, there was an alarming number of students who majored in HTM but never entered the industry after graduation. Although hospitality programs were developing highly qualified professionals, many of the students had no interest in working in the industry (Richardson, 2008). This, coupled with the increase in hospitality positions and need for qualified professionals, places the 
hospitality industry at a disadvantage. Further, examining the reasons why students are electing not to enter the industry, upon graduation, is an opportunity for this industry to understand how student variables (demographics, gender, year in school, and socioeconomic status (SES)) might further explain the reasons why students are opting out of the industry at graduation.

\section{Negative Hospitality and Tourism Industry Attitudes and Perceptions}

Although the literature identified reasons why students select HTM as a major, there are numerous studies that have found reasons why students have a negative attitude or perception of the hospitality industry. Scholars have examined factors influencing student career choice and student job-related motivators to better understand students' perspectives (Grobelna, 2017; Richardson, 2009; Richardson \& Butler, 2012). Through these studies, they have found that some students also have negative attitudes and perceptions of the hospitality industry. One significant study (Richardson, 2008) assessed what students found important in a career and then surveyed if they thought the industry could provide them with those factors. The most important factors that students identified included: an enjoyable job, favorable working environment, and a secure position. When Richardson surveyed the same students to see if they thought the hospitality industry could offer these important career factors, results showed that most students did not feel as though the hospitality industry could provide what they deemed important in a career. In fact, the majority of respondents did not indicate that the hospitality industry could provide any of the perceived important factors in a career (Richardson, 2008). Subsequent studies similarly found differences between what students valued in a career 
and their opinion that the hospitality industry could not provide it (Grobelna, 2017; Richardson \& Butler, 2012; Richardson \& Thomas, 2012). Richardson (2009) then indicated a few suggestions regarding how companies and programs can meet students' needs. For example, the hospitality industry will need to focus on ensuring students have positive work experiences prior to graduation. Industry professionals will also be tasked with changing students' perceptions regarding potential career paths. Universities will need to give students more emphasis on hospitality career paths, job expectations, and example pay scales. This will ensure that students are graduating with a realistic perception of a career within the industry (Richardson, 2009).

Several studies (Grobelna, 2017; Qiu et al., 2017; Richardson, 2008) incorporating all hospitality emphases revealed an inverse relationship between industry experience and intent to work in the hospitality industry. In other words, the more experience in the industry students acquired, the less likely they were to enter the industry upon graduation. Students who did not have exposure to the hospitality industry were more likely to want a career in hospitality after graduation (Richardson, 2008). Additional reasons that students chose not to enter the industry were: low salary (Kusluvan \& Kusluvan, 2000; Mohd Zahari, 2004), lack of a work/life balance (Kusluvan \& Kusluvan, 2000), demanding hours (Chan, 2017; Gitau, 2016; Richardson \& Butler, 2012), irregular shifts (Akin Aksu \& Deniz Köksa, 2005), and negative relationships with managers (Akin Aksu \& Deniz Köksa, 2005; Kusluvan \& Kusluvan, 2000; Richardson, 2008).

Another reason why students might have a negative perspective of the industry was that hospitality may not have been their first career choice. If students did not choose 
hospitality as their first choice, they may have had little to no knowledge of or exposure to the industry (Kusluvan \& Kusluvan, 2000; O'Mahony et al., 2001). This suggests that students may not have understood the challenges and demands of the industry upon entering HTM, thus leading to quick turnover after entering the industry. For example, one study (O’Mahony et al., 2001) found that, of the hospitality students polled, only $10 \%$ knew that they wanted to choose HTM as a major before they enrolled in the university. This would indicate that some students chose a university first and then selected HTM as a major once enrolled. Lu and Adler (2008) found that one-third of the students not entering the industry upon graduation cited reasons such as having no personal interest or desire to work in the industry. This may be attributed to a random major selection or HTM not being a first choice.

Additional reasons for not entering the industry included tedious work (Qiu et al., 2017), inconsistent work due to seasonality (Akin Aksu \& Deniz Köksa, 2005; Chan, 2017; Kusluvan \& Kusluvan, 2000; Mohd Zahari, 2004; U.S. Bureau of Labor Statistics, 2010), and the perception that a career in the industry would not lead to a satisfactory life (Akin Aksu \& Deniz Köksa, 2005; Chan, 2017; Kusluvan \& Kusluvan, 2000;). Not surprisingly, students felt that the disadvantages of the hospitality industry outweighed the advantages, and over half the respondents reported that they would not want their children to pursue a career in the industry (Kusluvan \& Kusluvan, 2000).

\section{Differences Based on Student Variables}

Research has shown that hospitality students have conflicting attitudes and perceptions regarding the industry. Due to this, scholars have explored multiple student 
variables to better understand what contributes to positive or negative industry perceptions while acknowledging that HTM students are not a homogenous population. Studying students' industry attitudes and perceptions will help universities and the industry in further understanding students' views, which could lead to changes in programing, recruitment and student advising. Therefore, this study will continue to explore the student variables of gender, level of schooling, emphasis, SES, and prior industry exposure. Below is the extant literature regarding the variables scholars have already examined including, gender, level of schooling, geographical location, major emphasis, parental income, and family SES.

Influence of gender. A common factor that was aggregated when studying HTM students was gender. Gitau (2016) revealed that gender was a major predictor in students' career decisions in the hospitality industry. Hjalager (2003) found a difference in motivation between male and female hospitality and tourism students when selecting the hospitality industry as a career. This study revealed that males tend to have more ambitious career goals compared to females. Additionally, Hjalager found that females had greater motivation for a good salary and international travel, while males were motivated by previous work experience. Conversely, Malgwi, Howe, and Burnaby (2005) found that male students studying business indicated that salary was a strong influencer when selecting a major, while females reported their perceived ability to succeed in the industry. Chuang and Dellmann-Jenkins (2010) discovered that females had stronger career intentions than males. Another study (Kim et al., 2010) found that leadership 
development was more important to males, whereas serving society was of greater importance to females.

Other studies (Chuang et al., 2007; Lee et al., 2008; Qiu et al., 2017; Richardson \& Thomas, 2012) found no differences along gender lines. For example, Qiu et al. (2017), Chuang et al. (2007), and Lee et al. (2008) found no significant differences along gender lines in the top motivational or importance factors in career decision. Another study (Chuang et al., 2007) found no difference in career outcome expectations or career goals between males and females.

One factor related to gender was family influence. When it came to family influences, females were more likely to be influenced by their parents (Chak-keung Wong \& Jing Liu, 2010), while another study determined that males were likely to be more influenced by relatives (Kim et al., 2010). Chan (2017) found that a higher percentage of females intended to work in the hospitality industry.

Scholars agree that clear differences exist between genders regarding the chosen segment of the industry students would like to enter upon graduation. Females rated the events industry more favorably than males (Chuang et al., 2007; Kim et al., 2010; Lee et al., 2008), and males were likely to express greater interest in the food and beverage sector compared to females (Chuang et al., 2007; Lee et al., 2008).

Influence in the level of schooling. There were clear differences in students' influences, perceptions, and career expectations when comparing their level of schooling. For example, freshmen ranked their faculty and counselors as important in their career choice (Qiu et al., 2017). In this study, freshmen were more likely than sophomores to 
describe a career in hospitality as interesting and challenging. This could be due to the fact that during their sophomore year, students had an undefined working experience within the industry, likely causing the decrease in their industry perception (Chan, 2017). First-year students also demonstrated the strongest motivation to work in the industry (Chan, 2017).

Another study (Blomme, Van Rheede, \& Tromp, 2009) examined students' perspectives at three different levels: pre-entry of their first-year, graduates, and industry employees. Pre-entry/first-year students had higher perspectives of industry salary and career opportunities, suggesting that students were entering HTM with inflated expectations of the industry's pay and career possibilities. Unsurprisingly, perceptions of the industry changed as students acquired industry experience (Blomme et al., 2009). Compared to freshman and sophomores, juniors and seniors were more open to broader career options and pathways (Chuang et al., 2007). In summary, research indicated that students' year in school clearly made a difference in their perceptions and attitudes regarding the hospitality industry, thus making it essential to include year in school as a variable in this study. This variable will also assist in answering research question number three regarding how students' year in school affects industry attitudes, career goals, and career decision self-efficacy.

Differences based on country of residence. It is plausible that the difference in career expectations, industry intent, and gender could be attributed to the cultural differences and/or the country of residence of the students. A number of scholars (Chak- 
keung Wong \& Jing Liu, 2010; Lu \& Adler, 2008; Qiu et al., 2017; Zhao, 1991) specifically focused on researching Chinese students studying HTM.

The top reasons for Chinese students selecting HTM as a major included opportunity for growth and ability to meet people from different cultures (Lu \& Adler, 2008). Chinese students' career aspirations included having a high-level and powerful job, high income, and having the ability to pursue personal interests (Lu \& Adler, 2008). According to a study conducted by Lu and Adler, only $16 \%$ of Chinese respondents chose HTM as their preferred major. This low percentage could be attributed to the national examination system in China which tracked students to certain career paths based on their test scores. Students in this study likely accepted HTM as a major because it was assigned to them by the university based on their low examination scores (Lu \& Adler, 2008). In contrast, Qui et al., (2017) found that students independently selected HTM as a major and were influenced by their perceived ability to become successful in the industry (self-efficacy) and their perceived career opportunities. Having high levels of self-efficacy and occupational aspirations served as motivators to stay in the industry (Qui et al., 2017).

The influence of parents on students' career decisions in China was also studied. In fact, parental influences could predict students' career intention (Chak-keung Wong \& Jing Liu, 2010). Chinese students chose an industry that made their families feel proud, but, hospitality did not rank high for Chinese parents. Another finding revealed that Chinese parents who had hospitality industry experience were more supportive of students studying HTM (Chak-keung Wong \& Jing Liu, 2010). Mohd Zahari (2004) studied students from Malaysia, China, and India and interestingly found little difference 
regarding industry perceptions except that Malay students were more optimistic about career opportunities, Indian students were more excited about the prospect of entering the industry, and Chinese students had more work experience and rated work in the industry as more stressful compared to the other nationalities (Mahd Zahari, 2004).

Another notable difference based on the country of residence was the industry segment students chose to enter. Lu and Adler (2008) discovered that a high percentage of Chinese students wanted to enter travel agencies and tourism, followed by the events industry. Students in Zimbabwe, in contrast, found the airline industry to be more enticing, followed by food and beverage, and the front office of a hotel (Gitau, 2016). Event management and hotels were the most interesting to students in New Zealand (Chan, 2017), while students from the United States ranked hotels and event management highest respectively (Richardson \& Thomas, 2012).

Students who studied HTM in Sweden were motivated by the opportunity to work with people and by their personal and positive working experiences in the industry (Hjalager, 2003). Swedish students also placed greater importance on the social factors of a career rather than the salary or benefits. Students in Australia chose HTM due to their own personal interest and the influence of guardians and career advisors (O'Mahony et al., 2001). In a study that compared Polish and Spanish students (Grobelna, 2017), it was determined that both groups had similar perspectives about the hospitality industry and what it could offer as a career. Differences were noted that Polish students found jobrelated motivators more important, and Spanish students were more likely to believe that the hospitality industry could satisfy their career needs (Grobelna, 2017). Similarly, 
Greek students had more positive perceptions of the hospitality industry compared to students from the United Kingdom (Airey \& Frontistis, 1997). And, Richardson and Thomas (2012) revealed that American and Australian students agreed on the majority of the most important factors in a career including an enjoyable job, high earning potential, a positive environment, and job security.

Not surprisingly, the public perception of a career in the hospitality industry also varied by the country of residence. As was previously mentioned, Chinese parents did not find the hospitality industry to be a prestigious career choice (Chak-keung Wong \& Jing Liu, 2010). Additionally, 51\% of Turkish students agreed that the hospitality industry was not prestigious (Kusluvan \& Kusluvan, 2000). In contrast, 59\% of American students felt that working in the industry was respectable (Richardson \& Thomas, 2012).

Additional differences existed based on the students' geographical upbringing when students from the same university were compared. A Malaysian study (Mohd Zahari, 2004) found that students from rural areas were less motivated regarding their career expectations than those who were raised in a city. This study also concluded that religious affiliation had little influence on the students' industry attitudes and perceptions (Mohd Zahari, 2004).

The above studies included country of origin as a variable, whereas this study surveyed students studying in the United States without asking respondents to identify country of origin. The current study helps contribute to the literature regarding students within the United States and the hospitality industry. Due to Mohd Zahari's (2004) finding, the study did not ask about geographical upbringing or religious affiliation. 
Influence of chosen study emphasis in the hospitality industry. Another way to group HTM students was by the segment of the industry they intended to enter. Stone et al. (2017) examined students studying HTM who intended to work in event management. This study surveyed students' expectations of the industry and what they perceived as being important to a future career. Students chose event management due to their perception that it could offer them an enjoyable job, a favorable working environment, and exciting opportunities. This study also found that students studying event management had realistic expectations of pay, workload, and the hours that they would be working. This expectation and overall satisfaction within the events industry were attributed to work experience and internships providing a realistic portrayal. Notably, the students believed that a career in event management surpassed their perceived career importance in the following characteristics: an enjoyable job, responsibility, and an exciting environment (Stone et al, 2017). In contrast to Stone et al., Dodds and Muchnick (2008) surveyed hospitality students and found that $85 \%$ did not think that event planners had an interesting or exciting position. This demonstrated the diverse opinions HTM students had about different segments of the industry and the careers that they offered. Based on the conflicting results, this study asked participants their current emphasis. This was incorporated in research question four as a subcategory of the demographic questions.

Influence of family socioeconomic status for hospitality students. Limited research exists regarding students' SES as a factor when trying to understand the career expectations and motivation of HTM students. Gitau (2016) found that when students' 
personal background factors (family, friends, mentors, and industry perception) were positive influences, that led to more satisfaction in their studies and greater intention to seek a career in the industry after graduation. Perhaps one of the most comprehensive studies that included students' SES was Chak-keung Wong and Jing Liu (2010). This study examined parental influence and income. Some of the results indicated that students were negatively impacted if their parents had low incomes (Chak-keung Wong \& Jing Liu, 2010). The study showed that the lower the SES of the family, the less support students received in studying HTM. The lack of support was attributed to the parents' perception that the hospitality industry was not seen as a prestigious career (Chak-keung Wong \& Jing Liu, 2010). Additionally, parents from a lower SES placed an importance on choosing a career that could elevate the family's living standards and status (Chak-keung Wong \& Jing Liu, 2010). Conversely, parents from a higher SES provided more physical and psychological support, which could have aided in career development and played a positive role in the students' career choice process regardless of the major selected (Chak-keung Wong \& Jing Liu, 2010). In contrast, Mohd Zahari (2004) examined Malaysian students' pursuit of a career in the hospitality industry as it related to their parents' SES. The parents' SES was defined based on their occupation, highest level of education, and family income. Results indicated that parental background did not differ when examining students' attitudes towards the hospitality industry (Mohd Zahari, 2004). The author also surveyed students' attitudes regarding the hospitality industry comparing private and public schools in Malaysia. Students' parental occupation was found to be significant with a greater concentration of fathers of private school 
students working in professional management and supervisory levels. Another significant finding was that the average annual income was higher at private schools. The tuition difference of private and public schooling was another way that Mohd Zahari (2004) examined differences based on family SES. Mohd Zahari (2004) and Chak-keung Wong and Jing Liu (2010) reported that SES was a crucial variable to examine when studying students' career decision making processes thus, students' SES was surveyed in this research study.

The majority of studies concluded that there were differences in students' perceptions about the hospitality industry and career expectations based on their gender, level of schooling, country of residence, selected emphasis, and parental income/ family socioeconomic status. It could be concluded that HTM students should not be considered a homogeneous population. Many other factors contributed to students' attitudes and their career expectations in the hospitality industry.

Lack of research regarding hospitality students' SES. Chak-keung Wong and Jing Liu (2010) found a difference in career selection and support for students studying HTM in China based on the family's SES. Since this study, there has been limited research regarding students' SES and its impact on their career goals and expectations. Research (Mohd Zahari, 2004) that was conducted prior to this study offered conflicting results. Kusluvan and Kusluvan (2000) noted that relationships regarding students' attitudes towards the hospitality industry and their SES should be examined for future research. A recent study (Grobelna, 2017) also called for future research on families' SES and how that impacts students' career choice. One must consider students' SES when studying 
HTM students As seen from Chak-keung Wong and Jing Liu (2010), students from a lower SES were more likely to have parents who viewed the industry negatively and offered less emotional and physical support in the career development process within the Chinese cultural context. Chak-keung Wong and Jing Liu's (2010) study was enlightening and gave researchers and the industry a glimpse into how SES affects students' career development in HTM; however, this study was conducted in China and may not be generalizable due to cultural differences. Unfortunately, there is a gap in research regarding how students' SES affects their attitudes regarding the industry and career goals and expectations, particularly for students studying HTM in the United States. This lack of research could lead to a negative vocational impact for the hospitality industry. Research question one of the current study sought to explore how students' SES affected their industry attitudes, career goals, and career decision self-efficacy. This question helps address the limitations found in the literature regarding students' SES.

\section{Profile of General Students from a Low Socioeconomic Status}

To better understand how SES affects students studying HTM, it is important to consider how SES affects students in general. Students from a lower SES were less likely to attend college (Walpole, 2003). Students who came from a low SES typically experienced equity issues due to the fact that they were typically underrepresented in policy (Walpole, 2003). For example, one study (Walpole, 2003) found that nine years after entering college, low SES students had lower incomes, lower graduate school attendance rates, and lower educational achievement. Walpole also noted that students with a low SES had less interest in obtaining a medical or law degree compared to those 
from a high SES. Surprisingly, even if students from a low SES attended and graduated from graduate school, their income was still less than students who were not from a lower SES (Walpole, 2003).

Students with a low SES had lower educational outcomes compared to students from a high SES, suggesting that their social class negatively affected their achievements (Walpole, 2003). The negative effects of being a student from a low SES continued even after graduation. Graduation was not an equalizer among the socioeconomic classes. Students who came from a higher SES continued to have advantages over the students from a lower SES (Walpole, 2003).

Leppel, Williams, and Waldauer (2001) found that students' SES affected their major selection. Additionally, Ma (2009) found that students from a low SES favored majors that had greater perceived job opportunities. Students from a low SES were more likely to select business, technical or health fields as a major. When compared to humanities and social science majors, these majors provided more job opportunities and greater economic returns (Ma, 2009). Staniec (2004) found that the higher the family income, the less likely a student chose a technical major. Staniec (2004) examined family income as it related to students selecting math, engineering, or science as a major. The study concluded that there was no significant relationship between family income and students' selection of a math, engineering, or science major (Staniec, 2004).

Hsieh and Huang (2014) found that a father's educational attainment and occupation were significant determinants of a family's SES. This suggested that the father's, compared to a mother's, occupation and educational attainment were more of a 
contributing factor to a family's SES (Hsieh \& Huang, 2014). Concerning college major selection, Staniec (2004) found that parental occupation had a limited effect on student major selection and that parental education attainment had very limited effects (Staniec, 2004).

Family SES was positively correlated with student career self-efficacy (Hsieh \& Huang, 2014). For this reason, family and parental units were important influences on student career decision making (Hsieh \& Huang, 2014). Students who had higher perceived support from their parents and peers had fewer perceived barriers (Ali, McWhirter \& Chronister, 2005). Additionally, Hill, Ramirez, and Dumka (2003) found that students from single-parent households were just as likely to identify their homes as supportive compared to households with both parents.

Parents from a low SES demonstrated less parental support and less parental involvement in student career decision making (Hsieh \& Huang, 2014). Students who identified their families as unsupportive typically demonstrated limited and undefined goals (Hill et al., 2003). Conversely, students from families with a high SES benefited from more than just emotional support, including more resources and parental social capital that could further advance students in their careers (Ma, 2009).

Stressors associated with low income. Students from a lower SES reported lower levels of confidence and career decision self-efficacy compared to those of a higher SES (Hsieh \& Huang, 2014). An additional stressor associated with students from a low SES included that they typically spent more hours at work than their peers from a high SES (Walpole, 2003). Consequently, they spent less time studying, thus resulting in lower 
GPAs (Walpole, 2003). Students may also have experienced stressors associated with their low SES neighborhoods (Hill et al., 2003). Some of these stressors included fear of gang violence and being robbed (Hill et al., 2003). Additionally, students from a low SES saw their parents struggling financially, which could also have increased stress (Hill et al., 2003).

Gender influences versus socioeconomic status on major selection. Some scholars (Hill et al., 2003; Leppel et al., 2001; Ma, 2009) examined how the role of SES and gender interacted. Hill et al. found that males demonstrated stronger career goals compared to females. Ma noted that SES had differing effects when examining gender and major selection. Leppel et al. (2001) noted that as the SES increased, females were more likely to select a major in the humanities or social sciences field. In contrast, as SES increased for males, they were more likely to select education, health, or sciences compared to business. Both genders increasingly chose humanities and social sciences as SES increased (Leppel et al., 2001). Ma (2009) noted that females typically leaned towards more service professions compared to men. Furthermore, females from a lower SES were just as likely as their male counterparts to choose a major that had high earning potential. Conversely, for males and females from a higher SES, there was still a gender difference in career choice with males choosing those with larger earning potential (Ma, 2009). Ma (2009) found that for women from a lower SES, their social class was more influential than gender on their major selection.

Interaction of race and ethnicity and socioeconomic status. Ma (2009) examined how race interacted with students' socioeconomic status and found that SES was a more 
powerful factor than race. She concluded that the higher the SES, the less likely students were to select a technical or business career and would instead choose social science or the arts and humanities field. Conversely, Leppel et al. (2001) found, when comparing similar levels of students' SES, white students were more likely than black or Asian students to select business as a major.

Hill et al. (2003) studied perceived barriers associated with race and ethnicity. The study looked at Mexican immigrants and Mexican adolescents who may have additional stressors, including immigration status and English proficiency (Hill et al., 2003). Despite having these barriers, Mexican immigrants and Mexican American children were less likely to identify as having barriers compared to Euro and African American children (Hill et al., 2003). Additionally, Euro-American and African American children identified their families as being unsupportive compared to Mexican immigrants and Mexican Americans who considered their families to be supportive (Hill et al., 2003).

Although race and ethnicity contributed to differences in perceived barriers and major selection, Ma (2009) found that the interaction between SES and gender was greater than the interaction of SES and race and ethnicity. This could possibly mean that there was more of a gender divide, compared to race and ethnicity, in college major selection (Ma, 2009).

Students' SES is a critical factor since researchers have determined that SES can be a strong variable that influences responses. Thus, the current study asked participants their race/ethnicity, gender, and SES. This information aided in answering research question four regarding how students' demographic characteristics, including SES, influences their 
industry attitudes, career goals, and career decision self-efficacy. Such findings could contribute to the conflicting evidence regarding how demographic characteristics and SES influence the aforementioned variables.

\section{Theoretical Framework: The Social Cognitive Career Theory}

Several hospitality scholars (Chak-keung Wong \& Jing Liu, 2010; Gitau, 2016; Lu \& Adler, 2008; Qui et al., 2017; Stone et al., 2017) who studied students' industry perceptions and career decisions drew from the theoretical framework of the Social Cognitive Career Theory (SCCT) (Lent, Brown \& Hackett, 1994). Scholars outside the hospitality industry have also used the SCCT to better understand students from a low SES (Ali et al., 2005; Garriott, Flores \& Martens, 2013; Hsieh \& Huang, 2014). The SCCT is an expansion of Bandura's (1986) general Social Cognitive Theory (SCT) and incorporates other theories surrounding career decision (Krumboltz, Mitchell \& Jones, 1976) and career development (Hackett \& Betz, 1981).

The SCCT is a popular theory for studying students from a lower SES because the theory acknowledges the interacting influences of person, behavior, and environment (Lent \& Brown, 1996). The SCCT identifies three variables (self-efficacy beliefs, outcome expectations, and personal goals) that influence a person's career decision process (Lent \& Brown, 1996). Self-efficacy beliefs are linked to self-belief in the ability to perform activities at work and school. Self-efficacy beliefs are obtained and/or changed by four sources: personal performance accomplishments, vicarious learning, social persuasion, and physical states and reactions (Lent et al., 1994). Self- efficacy 
beliefs within SCCT influence one's outcome expectations and personal goals. For this reason, this study examined self-efficacy beliefs within the SCCT.

The vocational interests element of the theoretical framework explores how a child's environment and activities have potential career importance. Through repeated action and exposure to certain activities, a child can develop self-efficacy beliefs which could lead to certain career choices. Figure 1 gives a visual display of how Vocational Interests are developed in the SCCT. The SCCT recognizes that gender, race/ethnicity, genetics, and SES are variables that operate alongside the SCCT. This theory acknowledges that some individuals, due to lack of access to certain activities, might have limited and/or narrow vocational interests thus affecting their self-efficacy in certain careers (Lent \& Brown, 1996). As Lent, Brown and Hackett (2002) states “... persons living in poverty may fail to develop interests in particular career options because they may not have been exposed to opportunities and experiences that would lead them to feel efficacious about their abilities to pursue these careers or optimistic about the outcomes they might receive" (p. 272). 


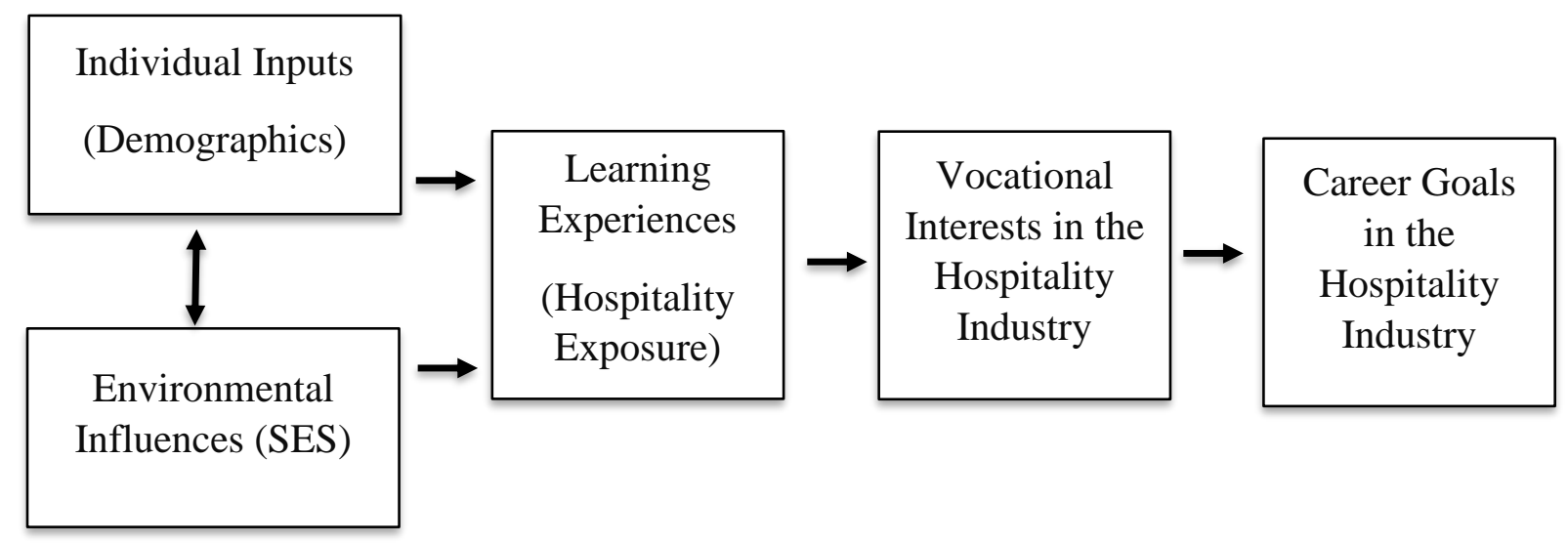

Figure 1. Vocation interest development in hospitality. Adapted from Lent, Brown, and Hackett (1994).

Based on the SCCT, children who are exposed to elements or activities within the hospitality industry would develop/strengthen their self-efficacy beliefs, thus leading to outcome expectations and personal goals within the industry. In other words, those who are exposed to the industry as children are more likely to believe that they can obtain a successful career within the industry. As mentioned by the SCCT, some children lack access to certain activities, thus narrowing their self-efficacy beliefs regarding certain career options. Based on the SCCT, when studying hospitality students' career decisions, one must first understand prior exposure to the hospitality industry by students from a lower (and/or higher) SES experiences. Thus, research questions one and two sought to explore how students' SES and prior industry exposure affect career goals, industry attitudes, and career decision self-efficacy.

Low socioeconomic status and characteristics of travel and tourism. In comparing annual travel expenditures based on income, there were vast differences based on the most recent, albeit somewhat outdated federal statistics. The lowest $20 \%$ of household 
income spent $\$ 415$ annually on entertainment, lodging, food and beverage, and transportation compared to the highest $20 \%$ spending $\$ 3,618$ per household (U.S. Bureau of Labor Statistics, 2010). The highest $20 \%$ of incomes spent more on travel expenses than the remaining $80 \%$ (U.S. Bureau of Labor Statistics, 2010).

Exposure limitations. People from a lower socioeconomic class tended to spend their leisure time in different ways. Stamps Jr. and Stamps (1985) found that those from the middle class read, participated in sports and recreation, and traveled more than those from a lower class. Additionally, lower income households rarely partook in costly leisure activities. Low income households did not spend much money on luxury items (Agrawal, Blumenberg, Abel, Pierce \& Darrah, 2011). As income rose, so did the expenses for vacation travel, leisure goods, and food expenses consumed outside of the household (Agrawal et al., 2011). Half of the lower income population group made no annual long-distance trips (Georggi \& Pendyala, 2001). When they did travel, the reason was typically for social purposes perhaps because the cost of lodging was not needed (Georggi \& Pendyala, 2001). Lower income households also utilized the bus system more and the airlines less, compared to other income groups when traveling (Georggi \& Pendyala, 2001). Anderson (2016) also stated that low income individuals are more likely to regularly utilize public transportation compared to those with higher income levels. Stamps Jr. and Stamps (1985) found that there was a higher correlation between social class and leisure spending than among those of the same race. Crompton (1979) identified children's education as a large motivator for travel. This notion suggested that a well-traveled child would become a well-rounded individual (Crompton, 1979). Those 
with lower income were spending less money for hotels, travel expenses, and restaurants compared to those from higher income groups. Peerapatdit (2004) stated that household income influenced expenses for lodging, restaurants, and retail. When examining the differences in leisure expenditures, the demographic variable of income was the only influencing factor on expenditures (Peerapatdit, 2004). Income was also a significant factor in the dollar amount respondents spent at a restaurant (Peerapatdit, 2004).

Based on these lower dollar amounts, one could conclude that people from a lower SES are not able to travel or experience the hospitality industry as often compared to those from a higher SES, thus experiencing less exposure to the industry. According to the SCCT, this lack of exposure to the breadth of the hospitality industry could lead to fewer vocational interests and less self-efficacy in the industry, which could negatively affect career decision self-efficacy (Lent \& Brown, 1996). Individuals from a higher SES would have the family means to have more experiences with the hospitality industry which could lead to greater self-efficacy and increased vocational interests. An increase in these variables could positively affect career decision self-efficacy within the industry. Exposure to the hospitality industry is a critical component in developing career decision self-efficacy. If SES is tied to exposure, one could hypothesize that the higher the SES, the greater the career decision self-efficacy a student will develop.

How students' SES affects their attitudes towards the hospitality industry and their perceived career expectations must be considered. Students from a low SES might not fully understand the scope of the industry if they lack prior personal family experiences and exposure. How could one then expect lower income students to understand an 
industry to which they had very limited access? Perhaps it is difficult for students from a low SES to conceptualize a career in a luxury hotel, a country club, a cruise ship, or a fine dining restaurant if they have limited to no exposure to these segments of the hospitality industry. Is it possible that students from a low SES who selected hospitality as a major have lower self-efficacy and lower career goals? If so, this could lead to a lower salary and fewer perceived opportunities compared to their peers from a higher SES. Students, regardless of their SES, deserve equity and the same opportunities for educational and career advancement.

Social justice in career services. The education of hospitality students may unknowingly exclude individuals based on their SES. Students from a low SES do not have the same opportunities for advancement nor do they achieve the same outcomes compared to those from a higher SES (Hooley \& Sultana, 2016). Arthur (2014) states that certain populations, based on SES, obtain more access to academics and career resources due to practices of discrimination and oppression. Hooley and Sultana (2016) stated, "There is a long tradition of research which demonstrates that people's careers are socially constructed and socially constrained" (p. 3). This raises the question of how can the industry, and hospitality programs, assist students from a low SES in having the same resources as someone from a higher SES in order to develop a successful career in the hospitality industry?

Universities are becoming more diverse and are increasing efforts to retain underrepresented students. A career services team can aid in retention strategies for underrepresented students and can promote social justice programing (Fickling, 
Lancaster, \& Neal, 2018). Career services empower underrepresented students with the tools they need to become successful, including confidence and direction for obtaining their career goals (McIlveen, Everton, \& Clarke, 2005). Career services are not a one-size fits all approach. Different students need different programing for success. Fickling, Lancaster, and Neal (2018) surveyed directors of career centers and found that the directors saw the social justice component in their work. Although career services involves helping all students, careful consideration should be given to students who are underrepresented. The directors indicated that success was obtained when students developed lifelong skills for career management and self-advocacy. Most directors also noted that they see their role as advocating on behalf of students within the institution and with employers.

Faculty and career counselors have the ability to create and administer interventions for students to increase their self-efficacy within the industry. Individuals who offer career advising are agents of social justice who promote social change (O'Brien, 2001). McIlveen, Everton, and Clarke (2005) argue for early career services advising as a strategy for promoting social justice. They noted that students who have stronger career knowledge will have higher retention rates. Career services personnel can aid underrepresented populations while influencing institutions and policy (O’Brien, 2001). Education and career training are tools to escape poverty and develop a career. (O'Brien, 2001). Career services can influence social mobility (Mcllveen, Everton, \& Clarke, 2005). The transition from school to a career is a leverage point for social change. Career advisors who understand students and their barriers on an individual basis are agents of 
social change who promote social justice (O’Brien, 2001). Career advisors must understand how student environments (including SES) affect students' academic and career advances and help them understand their personal barriers to success (O'Brien, 2001). Advisors who understand students' backgrounds, especially those who are underrepresented, can tailor the content delivery in a way that is flexible to most students' needs (Fickling, Lancaster, \& Neal, 2018).

Hoolyey and Sultana (2016) posed a question regarding the role of career services: should career services develop skilled talent for industries by molding students into candidates that meets the requirements or should career services be emancipatory? Similarly, Arthur (2014) noted that career services should work with individuals as coparticipants and not solely encourage individuals into certain career paths based on predetermined industry employment needs. Arthur (2014) also mentioned that this notion becomes increasingly difficult when private funds are given to university programs based on labor needs. In line with Arthur's (2014) sentiments, the hospitality industry needs to develop programing to attract and retain the right candidates for the industry, rather than recruiting any able body to satisfy the labor shortage. Identifying the right candidates will aid in industry retention of talent and industry career advancement. Understanding how student variables affect their future career decision process is deeply rooted in social justice, which is a term omitted in previous studies regarding students' industry attitudes and career goals. Rooted in the SCCT and with a social justice mindset, this study sought to explore how students' SES, prior industry exposure, and level of schooling affect their 
industry attitudes, career goals, and career decision self-efficacy as undergraduate students studying HTM. 


\section{Chapter 3. Methodology}

\section{Introduction}

This chapter provides a description of the research design and methodology for the study. Included are definitions of the independent and dependent variables with descriptions of how they have been previously measured in the extant literature. The proposed assessment tools are thoroughly discussed, including evidence of their respective reliability and validity. The chapter also describes the participants, data collection methods, data analysis methods, possible limitations, and researcher positionality.

\section{Independent Variables}

The independent variables in this study are: 1) Socioeconomic Status; 2) Prior Industry Exposure; 3) Year in School; and 4) Demographics (i.e., gender, race, first generation status, emphasis, age).

Measuring socioeconomic status and parental education. The way in which scholars measure SES varies per study. Table 2 offers a visual display of how ten studies, referenced in the literature review, measured SES. The most commonly used variable was parental education (Chak-keung Wong \& Jing Liu, 2010; Garriott et al., 2013; Hsieh \& Huang, 2014). For this reason, the present study will utilize parental education as one factor in determining students' SES. 
Table 2

Measures of Socioeconomic Status in Prior Research by Studies

\begin{tabular}{|c|c|c|c|c|c|c|c|c|c|c|}
\hline & $\begin{array}{c}\text { Hsieh } \\
\& \\
\text { Huang, } \\
2014\end{array}$ & $\begin{array}{l}\text { Garriott, } \\
\text { et al., } \\
2013\end{array}$ & $\begin{array}{l}\text { Walpole, } \\
2003\end{array}$ & $\begin{array}{l}\text { Raque- } \\
\text { Bogdan } \\
\& \\
\text { Lucas, } \\
2016\end{array}$ & $\begin{array}{l}\text { Leppel, } \\
\text { et al., } \\
2001\end{array}$ & $\begin{array}{c}\text { Hill, } \\
\text { et } \\
\text { al., } \\
2003\end{array}$ & $\begin{array}{c}\text { Georgi } \\
\& \\
\text { Pendyala } \\
\text {, 2000 }\end{array}$ & $\begin{array}{c}\text { Mohd } \\
\text { Zahari, } \\
2004\end{array}$ & $\begin{array}{c}\text { Chak- } \\
\text { keung } \\
\text { Wong } \\
\& \\
\text { Jing } \\
\text { Liu, } \\
2010\end{array}$ & $\begin{array}{l}\text { Ma, } \\
2009\end{array}$ \\
\hline $\begin{array}{l}\text { Parental } \\
\text { occupation }\end{array}$ & $\mathrm{X}$ & $\mathrm{X}$ & $\mathrm{X}$ & & & & & $\mathrm{X}$ & & $\mathrm{X}$ \\
\hline $\begin{array}{l}\text { Parental } \\
\text { education }\end{array}$ & $\mathrm{X}$ & $\mathrm{X}$ & $\mathrm{X}$ & & $\mathrm{X}$ & & & $\mathrm{X}$ & $\mathrm{X}$ & $\mathrm{X}$ \\
\hline Parental income & & & $\mathrm{X}$ & $\mathrm{X}$ & & & & & $\mathrm{X}$ & \\
\hline $\begin{array}{l}\text { Household } \\
\text { resources }\end{array}$ & & $\mathrm{X}$ & & & & & & & & \\
\hline $\begin{array}{l}\text { NCES } \\
\text { determination }\end{array}$ & & & & & $\mathrm{X}$ & & & & & \\
\hline $\begin{array}{l}\text { Family income } \\
\text { Income per } \\
\text { household } \\
\text { member }\end{array}$ & & & & & & & $\mathrm{X}$ & $\mathrm{X}$ & & $\mathrm{X}$ \\
\hline $\begin{array}{l}\text { Neighborhood } \\
\text { with less than } \\
\$ 25,000 \text { median } \\
\text { income }\end{array}$ & & & & & & $\mathrm{X}$ & & & & \\
\hline $\begin{array}{l}\text { Public housing } \\
\text { occupancy }\end{array}$ & & & & & & $\mathrm{X}$ & & & & \\
\hline $\begin{array}{l}\text { Socioeconomic } \\
\text { Index Score of } \\
\text { occupations }\end{array}$ & & & & & & & & & & $\mathrm{X}$ \\
\hline $\begin{array}{l}\text { Composite } \\
\text { measure created } \\
\text { by the NELS }\end{array}$ & & & & & & & & & & $\mathrm{X}$ \\
\hline
\end{tabular}

Note : NCES = National Center for Education Statistics, NELS = National Educational Longitudinal Study

Although various studies (Chak-keung Wong \& Jing Liu, 2010; Hsieh \& Huang, 2014; Leppel et al., 2001; Mohd Zahari, 2004) have used parental education in determining students' SES, the sub-classifications of parental education have not been consistent. For example, Chak-keung Wong and Jing Liu (2010) offered three options including: less than high school, senior high school and college/university and above, 
while Hsieh and Huang (2014) offered five choices including: junior high school, high school, partial college or specialized training, college, and graduate. For the purpose of this study, the categories for parental education adopted and modified Hsieh and Huang's (2014) selection categories. Responses included: less than high school, high school graduate, partial college, two-year college degree, four-year college degree, graduate/professional degree, and I don't know.

Income via Pell grant status. Income is also an important and widely used factor in determining students' SES. Mohd Zahari (2004) noted that students might not know their parental or family income, which could alter the validity of their responses. To avoid this, some scholars (Mailhot \& Feeney, 2017; Meyers, 2016) have used students' Pell Grant eligibility as a factor in determining students' SES.

Federal Pell Grants are issued by the United States Department of Education to undergraduate students who demonstrate exceptional financial need (United States Department of Education, n.d.). Unlike typical student loans, most Pell Grants do not need to be repaid. A student's Pell Grant eligibility is calculated by determining the student's expected family contribution (EFC) (United States Department of Education, 2015). The EFC is the sum of a percentage of income and assets. The EFC is calculated according to the information given on a student's Free Application for Federal Student Aid (FASA). If students are eligible for a Pell Grant, then they have been identified as low income and in need of financial assistance for their education. For this reason, this study utilized students' Pell Grant eligibility as a factor in determining SES. Students 
were asked if they were eligible for the Pell Grant. Students had the options to select "yes", "no", or "I don't know" as responses.

Measuring prior industry exposure: tool development. Figure 2 depicts the development of the Prior Industry Exposure tool used in this study.

\begin{tabular}{|c|c|c|c|}
\hline $\begin{array}{l}\text { Consultation with a } \\
\text { research librarian } \\
\text { (No known } \\
\text { exposure } \\
\text { literature) }\end{array}$ & $\begin{array}{l}\text { Consultation with a } \\
\text { psychometrician } \\
\text { (List specific ways } \\
\text { an individual might } \\
\text { experience the } \\
\text { industry) }\end{array}$ & $\begin{array}{l}\text { Focus group with } \\
\text { content experts } \\
\text { (Identify levels of } \\
\text { exposure based on } \\
\text { activities/ confirm } \\
\text { activity list) }\end{array}$ & $\begin{array}{c}\text { Revise activity } \\
\text { list/ pilot } \\
\text { assessment } \\
\text { (Test tool and } \\
\text { content expert } \\
\text { recommendations) }\end{array}$ \\
\hline
\end{tabular}

Figure 2. Prior industry exposure tool development.

After an extensive literature review and consultation with a research librarian, this researcher was not able to locate an existing tool to measure students' prior exposure to the hospitality industry. Given the fact that exposure is a critical component in the SCCT, the researcher determined that a tool must be created for this study. The researcher then enacted five steps to develop such a tool.

In step one, the researcher conducted an exploratory interview with one hospitality content expert and discussed how students experience the HTM industry. Through this interview, the researcher explored construct validity and learned that exposure is routinely regarded as including both consumer and/or work experience in the hospitality industry. In addition, exposure to the industry can be through varied components (e.g., lodging, food and beverage, events, travel/tourism) of the industry and likely depends on frequency and breadth. The content area expert also provided advice regarding how and 
what the researcher should do with a potential focus group of other content area specialists whose advice was also being sought about how best to measure prior industry exposure (discussed later as step 3).

In step 2, the researcher consulted with a psychometrician regarding designing the assessment tool and its' content validity. As advised, the researcher developed a list of specific activities that students might be exposed to in the hospitality industry. The researcher compiled six different categories of the hospitality industry based on John Walker's Introduction to Hospitality, 6th Edition: Hotels; Restaurants; Managed Services; Travel and Tourism; Private Clubs; Meeting and Events. After the categories were defined, the researcher identified specific activities that a student might encounter in each category. In total, there were 53 activities on the initial list across the six categories.

In step 3, the researcher paired the content expert's advice (step 1) with the content areas (step 2) to develop focus group questions based on Bogdan and Biklen's (1992) suggestions about question design. In step 3, the researcher also conducted a focus group with four tenure/tenure-track faculty who held doctoral degrees in hospitality and tourism management and taught HTM at a four-year public university. The number of participants was chosen based on recommendations from Peek and Fothergill (2009), which indicated that focus groups with 3-5 participants maximized discussions and ran smoother than larger groups. The four participant-experts were given three researcherdeveloped student profiles that contained specific yet varied hospitality industry activities (drawn from the six aforementioned Walker categories) that differed based on frequency. Participants were told to consider each student profile as hospitality exposure from ages 8 
to 18 . Content experts were asked to describe the profiles' exposure to the hospitality industry as "extensive," "moderate," and "limited" based on the specific activities and the frequency of the activities. Through this discussion, the focus group provided specific examples of which specific activities were deemed indicative of "extensive exposure," "moderate exposure," and "limited exposure" to the hospitality industry. Additionally, the focus group suggested edits and verified the initial list of specific exposure activities and recommended 13 additional activities for a more inclusive list. In step 3, and as a result of the focus group, the researcher expanded the list and coded each activity as more likely associated with "extensive," "moderate," or "limited" exposure.

In step 4, the researcher conducted follow-up individual interviews with 3 of the 4 focus group experts to quantify how many of the 19 extensive exposure activities would likely qualify someone as having "high extensive exposure", "extensive exposure", "moderate extensive exposure," and "limited extensive exposure" (see Table 3). Steps 3 and 4 continued to support the assessment tool's content and construct validity. 
Table 3

Quantifying Extensive Exposure HTM Activities

\begin{tabular}{lccc}
\hline & Expert 1 & Expert 2 & Expert 3 \\
\hline High Extensive Exposure & 5 & 5 & 8 \\
Extensive Exposure & 4 & 4 & $5-7$ \\
Moderate Extensive Exposure & 3 & 3 & 4 \\
Limited Extensive Exposure & 2 & 2 & 1 \\
\hline
\end{tabular}

Note. Expert's suggestions regarding quantifying the number of extensive exposure activities.

In step 5, the researcher created a draft of a paper-based pilot survey of the prior exposure tool using all of the previous information learned in steps 1 to 4 . The draft included a self-selection of one's exposure classification to the hospitality industry (i.e., "high extensive", "extensive", "moderate", and "limited" exposure) as well as the 19 activities that were deemed "extensive exposure" and 10 activities that were deemed "moderate exposure" by the content experts. The paper surveys were field tested on 40 HTM students in two sections of a hospitality course at a public university. The majority of participants were juniors, and all had declared HTM as their major. Participants first self-identified their summary opinion of their industry exposure classification from ages of 8 to 18 ; then they marked any of the 29 activities in which they had prior exposure.

Results indicated that $60 \%$ of the surveyed participants would be categorized as having "extensive exposure" according to the activities they selected, yet only $38 \%$ of the participants self-identified as having prior extensive exposure. Based on this limited 
sample, the researcher determined that asking students to self-identify might not properly place them in the extensive category as defined by the content experts. Results also indicated that using a rank ordering system for students based on their activities might yield more reliable results for exposure categorization for this study. In summary, the results from the pilot study indicated that a rank ordering system, based on the number of activities a student participated in, should be used. This will allow for comparison of the differences between the upper and lower quartiles of exposure. The pilot data offered initial insights regarding the assessment tool's measurement precision (reliability) and applicability to HTM students.

Prior industry exposure assessment research design and instrument validity. The tool designed to assess students' prior industry exposure was created by the researcher and followed the assessment triangle framework as outlined by the National Research Council's (2001) Knowing what students know: The science and design of educational assessment. The assessment triangle maintains that a developer must focus on Cognition, Observation, and Interpretation when designing a tool. The Cognition aspect of this tool is grounded in the SCCT. The Observation aspect was created based on Walker's (2012) Introduction to Hospitality book and later amended and validated by a focus group of content experts. According to the American Educational Research Association (AERA), American Psychological Association, and National Council on Measurement in Education (2014), this step demonstrates a source of validity evidence for this tool. Marshall and Rossman (2014) also state that focus groups give "face validity" to the results. Content experts were asked for suggested cut scores based on the activities 
deemed "extensive exposure"; this process demonstrates the Observation aspect of the assessment triangle. Having expert judges review item scoring and criteria is also a test design and development standard discussed by the AERA. Having conveyed these strengths, the tool designed by the researcher for the purpose of this study has otherwise not been validated.

Defining year in school. The students' year in school is a variable that must also be considered. Year in school will include the self-selected options of: Freshman; Sophomore; Junior; or Senior. These choices were selected since they are common terms that are familiar to most higher education students and because universities are somewhat inconsistent in equating academic credits with year in school.

Demographics. The survey will include demographic questions deemed important and influential by other researchers. These demographics include: gender, ethnicity, industry emphasis, age, and whether the students are first generation, and/or international college students.

The gender categories were taken from San Jose State University's (2016) gender categories. Categories include: Female, Man, Intersex, Transman, Transwoman, Genderqueer, and Other. Ethnicity options were taken from the California State University Enrollment, Fall 2018 Profile. Options included: African American, American Indian or Alaskan Native, Asian American, Filipino, Mexican American, Mexican, Other Latino, Pacific Islander, White Non-Latino, and Unknown. The category of Mixed Race was added for participants who identified with more than one ethnicity. 


\section{Dependent Variables}

The dependent variables in this study are: 1) Industry Attitudes; 2) Career Goals; and 3) Career Decision Self-Efficacy.

Measuring attitudes and career goals. Kyriacou and Coulthard (2000) developed a scale that explored undergraduates' perceptions of teaching as a career choice. Kusluvan and Kusluvan (2000) modified Kyriacou and Coulthard's (2000) scale and developed a multi-dimensional and multi-attitudinal scale to measure HTM students' attitudes and perceptions of working in the hospitality industry. The scale consist of a five-point Likert scale that examines nine dimensions of attitudes previously identified in the literature including: the respondent's attitudes toward nature of work, social status, industry-person congeniality, physical working conditions, promotion opportunities, pay/benefits, coworkers, management, and commitment to the industry. Multiple variations of this scale have been used and/or modified by numerous hospitality scholars when studying students' industry attitudes and perceptions (Chan, 2017; Richardson \& Butler, 2012; Stone et al., 2017).

Career goals. Richardson (2008) designed a survey which was derived from Kusluvan and Kusluvan (2000) and Kyriacou and Coulthard (2000) and has been used by recent hospitality scholars (Stone et al., 2017). Richardson (2008) included questions regarding students' career expectations and aspirations. Much like the Kusluvan and Kusluvan (2000) scale, it also included demographic questions, career aspirations, and an

attitude scale. Richardson included additional questions regarding career expectations and 
work experience, but these additional questions were not initially examined for their validity.

Demographic questions consisted of gender, enrollment units, student type (domestic/international), year in school, major, and emphasis. Career aspiration questions examined students' work history, including whether or not they worked in the industry and for how long, position and title, and how the work experience influenced their perception of working in the industry. Richardson (2008) also asked questions about students' expectations for future careers, including position, salary, and their perception if their expectations were realistic.

Based on the survey designed by Richardson (2008) that incorporated the Kusluvan and Kusluvan (2000) attitude scale which was used in numerous hospitality studies (Chan, 2017; Richardson \& Butler, 2012; Stone et al., 2017), this researcher will use this tool to measure students' attitudes, perceptions, and career aspirations of the hospitality industry.

Industry attitude and career goals: tool reliability and validity. Kusluvan and Kusluvan (2000) developed the scale after conducting an extensive literature review on industry attitudes and attitudes about working in the hospitality industry. From this, Kusluvan and Kusluvan identified nine dimensions within the construct: nature of work, social status, industry-person congeniality, physical working conditions, pay/fringe benefits, promotion, co-workers, managers, and commitment to the industry. Next, Kusluvan and Kusluvan utilized two focus groups of students to further understand their feelings about working within the industry. A series of questions was designed to 
measure students' relevant attitudes. The scale was created and pre-tested with 13 hospitality and tourism management schools. The scale has 79 items on a five point Likert scale ranging from "strongly agree" to "no opinion". Cronbach's alpha was used to measure reliability and internal consistency. The reliability for the entire scale was .93 . Table 4 demonstrates the reliability of its subcategories. A later study (Akin Aksu \& Deniz Köksa, 2005) showed support for the reliability of the scale with Cronbach's alpha at .84 .

Table 4

Kusluvan and Kusluvan's (2000) Scale Reliability by Sub-Category

Sub-Category

Reliability coefficient

(Alphas)

\begin{tabular}{lll}
\hline 1 & Nature of work & 0.72 \\
2 & Social status & 0.74 \\
3 & Industry-person congeniality & 0.81 \\
4 & Physical working conditions & 0.60 \\
5 & Pay/benefits & 0.65 \\
6 & Promotion opportunities & 0.81 \\
7 & Coworkers & 0.80 \\
8 & Managers & 0.86 \\
9 & Commitment to industry & 0.92 \\
\hline
\end{tabular}

Note. Adapted from Kusluvan and Kusluvan (2000).

Evidence of validity for this scale was demonstrated by four content experts (lecturers and researchers) in a hotel school. Content experts evaluated the content and face validity 
for the measured items. An item analysis was also performed, and evidence of convergent validity was found when the correlation among sub scores was significant (Kusluvan \& Kusluvan, 2000).

Measuring career decision self-efficacy (CDSE). This study will utilize The Career Decision Self-Efficacy Scale - Short Form (CDSE-SF) to measure the participants' degree of confidence in their ability to successfully make career decisions (Betz et al., 1996). The scale is comprised of 25 fixed choice questions with a five level confidence continuum ranging from "no confidence at all" to "complete confidence." Scores place students into three categories including; needing intervention, might need assistance, and comfortable with the skill set (Betz \& Taylor, 2012). This scale was utilized in studies throughout the literature review (Hsieh \& Huang, 2014) and it has also been used specifically to study hospitality students (Chuang \& Dellmann-Jenkins, 2010; Chuang et al., 2007). It should be noted that use of this instrument includes a cost incurred by the researcher but this researcher has no financial stake in the tool's use.

\section{Career Decision Self-Efficacy-SF tool reliability and validity. The CDSE-SF has} strong evidence for both reliability and validity. The CDSE-SF was developed with a strong foundation in theory. Specifically, Taylor and Betz (1983) incorporated the SelfEfficacy (Bandura, 1977) and Career Maturity (Crites, 1978) theories. Crites' model provided a framework for career decision-making that incorporated five subscales (selfappraisal, gathering occupational information, goal selection, planning for the future, and problem solving). Crites' subscales are utilized in the CDSE-SF. Reliability evidence includes an internal consistency (Cronbach's alpha) of .95 for the entire scale and .83 for 
test/retest. The internal consistency for each of the five subcategories ranged from .80 to .84. The validity evidence for this scale was demonstrated through a factor analysis and a confirmatory factor analysis (Betz \& Taylor, 2012).

\section{Description of Participants}

This study focused on four-year bachelor's degree undergraduate students who declared HTM as their major. Undergraduates enrolled in a two-year HTM associate's degree program were excluded from the study, as well as students who were considering, but had not yet declared, HTM as their major. Participants were at least 18 years of age and minors were excluded from participating in this study.

Participants in this study were undergraduate students at English-speaking universities in the United States. Therefore, it was anticipated that the participants had English-language literacy. It was not anticipated that undergraduate students pursuing a bachelor's degree had impaired decision making or needed a legally authorized representative to decide whether to participate in this study. Based on the demographics of the universities surveyed, it was anticipated that participants would have diverse backgrounds, i.e., gender, race, ethnicity. Permission to conduct this survey was given by the Institutional Review Board at San Jose State University (April, 2019).

\section{Recruitment}

The cross-sectional survey (Appendix 1) was disseminated to multiple universities with hospitality and tourism management bachelor's degree programs. Universities were selected from the researcher's professional network. An introductory email (Appendix 2), which explained the research objectives and included the link to the online Qualtrics 
survey, was given to hospitality program leaders at different universities. The email contained a brief introduction of the researcher, study, and notice that participation was completely voluntary and anonymous. Program leaders had the option to disseminate the survey, using the email provided, to the students in their programs. The email and link were also given to additional faculty members who are part of the researcher's professional network. Faculty had the choice to send the email and link to their students or post the opportunity in the appropriate channels (newsletter, listserv, online course forum, etc.). The researcher attempted to contact faculty and inquire about the number of possible students that might have received the research participation request however, not all faculty members responded. The unknown factor regarding how the link was distributed and the number of students it might have reached made it difficult in determining the response rate of the survey in conventional terms such as number of respondents (numerator) divided by the number of potential respondents (denominator) times 100. Instead, as discussed later, the response rate was based on the number of respondents (numerator) divided by the number of people (potential respondents) who opened the survey (denominator) times 100.

No participating institutions had access to which of their students chose to participate in the study nor the participants' responses. Consent was obtained through the Qualtrics platform on the first page. Consent was obtained in English as the potential participants were currently enrolled in an English-speaking university in the United States. Participants had the option to select either, "I agree to participate in the research study" or 
"I do not agree to participate in the research study". If the latter option was selected, the survey immediately ended.

The researcher anticipated 300 participants for a reasonable sample size. This number was determined by taking $10 \%$ of the total of the cumulative hospitality programs' enrollment. Three hundred respondents would also enable reliable inferential statistical procedures.

\section{Data Collection Methods}

Participants chose when and where to take the survey. Data were collected via the Qualtrics online survey platform. The Qualtrics website states that their software provides the highest levels of security and frequently surpasses data security expectations (Qualtrics, 2018). Qualtrics describes their secure data storage center as a non-public cloud-based system in an effort to prevent the hacking of data. Qualtrics does not sell participant data or make it known to any third party, including Qualtrics employees (Qualtrics, 2018). Qualtrics also provides features, including the option to turn off location tracking and prevent ballot box stuffing (i.e., taking the survey more than once from a specific IP address), both of which were incorporated into this study. For these reasons, the researcher decided to create the survey through the Qualtrics platform.

The survey included 160 questions. The survey was initially timed with three individuals and estimates suggested that it took 10 to 13 minutes to complete. Twentynine questions were asked for the independent variables of this study: SES (3), prior industry exposure (19), year in school (1), and demographics (7). The dependent variables consisted of 129 questions. Ninety-one questions came from Kusluvan and 
Kusluvan's (2000) industry attitude scale, and 13 questions came from Richardson's (2008) modification of the scale that included career goals and aspirations. An additional twenty-five questions were included from the CDSE-SF (Betz et al., 1996).

\section{Participant Incentive}

Upon completion of the survey, students were asked if they would like to enter a drawing for the chance to win one of four \$25 Amazon gift cards. Students were asked for their email address only if they wished to enter the drawing. E-mail addresses were only used to conduct the lottery and contact students who were awarded a gift card. The email addresses were deleted once the lottery was conducted.

\section{Data Analysis Method}

The quantitative data analysis begins with a description of respondents' demographic information. Demographic questions included gender, race/ethnicity, first generation status, major emphasis, and age. Next, the researcher provided descriptive statistics for each category, including the percentages, means, medians, and standard deviations. The researcher then applied inferential statistics (parametric and nonparametric) using the statistical software R Statistical Program Language and JMP. Analyses included correlations, factor analyses, ANOVAs, logistic regression analyses, linear regression analyses, chi-squares, relative ratios, and t-tests. Table 5 demonstrates which primary analyses were used per each research question. 
Table 5

Proposed Statistics by Research Question

\begin{tabular}{|c|c|c|c|}
\hline RQ 1 & IV (Data Type) & DV (Data Type) & Analysis \\
\hline & SES (CA) & Industry Attitude (CO) & Linear Regression \\
\hline & & Career Goals (CA) & Chi-Square \\
\hline & & $\operatorname{CDSE}(\mathrm{CO})$ & Linear Regression \\
\hline \multirow[t]{4}{*}{ RQ 2} & IV & DV & Analysis \\
\hline & Prior Industry Exposure (CO) & Industry Attitude $(\mathrm{CO})$ & Linear Regression \\
\hline & & Career Goals & Logistic Regression \\
\hline & & $\operatorname{CDSE}(\mathrm{CO})$ & Linear Regression \\
\hline \multirow[t]{4}{*}{ RQ 3} & IV & DV & Analysis \\
\hline & Year in School (CA) & Industry Attitude (CO) & $\begin{array}{l}\text { Proportion \& Chi- } \\
\text { Square Analyses }\end{array}$ \\
\hline & & Career Goals (CA) & $\begin{array}{l}\text { Proportion \& Chi- } \\
\text { Square Analyses }\end{array}$ \\
\hline & & $\operatorname{CDSE}(\mathrm{CO})$ & $\begin{array}{l}\text { Proportion \& Chi- } \\
\text { Square Analyses }\end{array}$ \\
\hline \multirow[t]{4}{*}{ RQ 4} & IV & DV & Analysis \\
\hline & Demographics (CA) & Industry Attitude (CO) & $\begin{array}{l}\text { ANOVA, Linear } \\
\text { Regression }\end{array}$ \\
\hline & & Career Goals (CA) & Logistic Regression \\
\hline & & $\operatorname{CDSE}(\mathrm{CO})$ & $\begin{array}{l}\text { ANOVA, Linear } \\
\text { Regression }\end{array}$ \\
\hline
\end{tabular}

Note. $\mathrm{RQ}=$ Research question, I.V. = independent variable, D.V.= dependent variable, $\mathrm{CO}=$ continuous data. $\mathrm{CA}=$ categorical data.

Linear regression was used when the dependent variable was a continuous number.

Linear regression was used to predict a dependent variable value based on the independent variables. Logistic regression was used when the independent variable was categorical. This analysis attempted to predict the dependent variable based on maximum 
likelihood. A chi-squared analysis was used to measure the expectant versus the observed data and an ANOVA was used to measure the general difference among groups. For the purpose of this, study a $p$ value of $\leq 0.05$ was used for indicating statistical significance.

\section{Summary}

Chapter three detailed the data collection methods for the proposed study. The specific measurement tools were introduced, including evidence of their reliability and validity. Next, the participants were discussed as well as the strategy for recruitment. Finally, a table was presented regarding the statistical analyses for each research question. 


\section{Chapter 4. Findings}

\section{Introduction}

This quantitative study explored how students' socioeconomic status (SES), prior industry exposure, year in school, and demographic characteristics affect industry attitudes, career goals, and career decision self-efficacy. This chapter will discuss the findings of the study as they relate to the research questions. First, demographic statistics of the students will be explored. Next, data for each research question will be examined. Finally, a comprehensive summary of the key findings and results will be presented.

\section{Students' Demographics}

The survey was open from $4 / 16 / 19$ to $6 / 2 / 19$. In total, 394 students opened the survey. Of those who opened the survey, three-hundred and fifteen students completed the entire survey $(n=315)(79.9 \%$ response rate). Students from 11 public universities completed the survey. Seven universities were located in California and responses also included students from Colorado, New Mexico, Washington, and Wisconsin. Seven campuses were located in urban cities and four self-identified as suburban campuses.

Gender and race. Seventy-nine percent of respondents were female, and Table 6 gives a visual description of students' self-reported race/ethnicity. The three most represented race/ethnicities included White (32\%), Asian (26\%), and Mexican American/Mexican (15\%). 
Table 6

Students by Race/Ethnicity

\begin{tabular}{lcc}
\hline Race/Ethnicity $(n=326)$ & Percentage & Number of Students \\
\hline White Non-Latino & $32 \%$ & 111 \\
Asian & $29 \%$ & 99 \\
Mexican, Mexican American & $15 \%$ & 50 \\
Mixed Race & $8 \%$ & 29 \\
Filipino & $5 \%$ & 18 \\
Prefer not to say & $2 \%$ & 8 \\
African American & $2 \%$ & 6 \\
Unknown & $1 \%$ & 4 \\
American Indian or Alaskan Native & $0.3 \%$ & 1 \\
\hline
\end{tabular}

Age, year in school, and first generation status. Students' ages ranged from 18 to 55 years old with the majority of students between 18 to 24 years old ( $n=238, M=23.1$ years). The majority of surveyed students were seniors (49\%) followed by juniors (32.3\%), sophomores (11.7\%) and freshmen (6.6\%). Ninety-one percent were domestic students, $8 \%$ were international students, and $1 \%$ preferred not to say.

Sixty-six students $(21 \%)$ were first generation college students with neither parent pursuing a higher education after high school. Students whose parents did not obtain a higher degree but took college level classes included 120 students (38\%). 


\section{Hospitality Related Demographics}

Emphasis. The most common emphasis was Event Management (33.9\%), followed by Hotel Management (33\%), and Food and Beverage Management (20.4\%). Eightyseven percent of the surveyed students chose one of these three emphases. Table 7 gives a visual representation of the hospitality-emphasis breakdown chosen by the students.

Table 7

Students by Emphasis

\begin{tabular}{lcc}
\hline Emphasis $(n=348)$ & Percentage & Number of Students \\
\hline Event Management & $34 \%$ & 118 \\
Hotel/Lodging Management & $33 \%$ & 115 \\
Food and Beverage/ Restaurant Management & $20 \%$ & 71 \\
Travel/Tourism Management & $7 \%$ & 25 \\
Other & $6 \%$ & 19 \\
\hline
\end{tabular}

Current and prior work experience. Seventy percent $(n=246)$ currently worked in the hospitality industry. Table 8 indicates the length of time that employed students have worked within the industry. Table 9 details the time basis in which students worked and Table 10 gives the average number of hours worked in a week. Table 11 indicates the percentage of students who worked part-time and full-time based on their SES status as defined by this study. 
Table 8

Length of Time Worked within the Industry

\begin{tabular}{lcc}
\hline Length of Time $(n=243)$ & Percentage & Number of Students \\
\hline 5 years+ & $26 \%$ & 62 \\
2 years to 5 years & $37 \%$ & 90 \\
12 months to 2 years & $18 \%$ & 43 \\
6 to 12 months & $11 \%$ & 27 \\
Less than 6 months & $9 \%$ & 21 \\
\hline
\end{tabular}

Table 9

Employment Time Base

Time Base of Employment $(n=326) \quad$ Percentage Number of Students

\begin{tabular}{lcc}
\hline Full-time & $25 \%$ & 64 \\
Part-time & $65 \%$ & 168 \\
Casual & $6 \%$ & 15 \\
Contract & $2 \%$ & 5
\end{tabular}


Table 10

Average Number of Hours Worked in a Week

\begin{tabular}{lcc}
\hline Weekly Hours $(n=239)$ & Percentage & Number of Students \\
\hline $41+$ & $7 \%$ & 16 \\
$36-40$ & $14 \%$ & 33 \\
$30-35$ & $12 \%$ & 29 \\
$26-30$ & $11 \%$ & 26 \\
$21-25$ & $14 \%$ & 34 \\
$16-20$ & $23 \%$ & 55 \\
$11-15$ & $9 \%$ & 21 \\
$6-10$ & $7 \%$ & 16 \\
$0-5$ & $4 \%$ & 9 \\
\hline
\end{tabular}

Table 11

Time Worked as a Group Percentage by SES Status

\begin{tabular}{lcc}
\hline & $20+$ Hours a Week & 36+ Hours a Week \\
\hline Low SES & $44 \%$ & $13.5 \%$ \\
High SES & $34 \%$ & $11.6 \%$ \\
\hline
\end{tabular}

Sixty-two percent $(n=151)$ of those currently working in the industry were employed in line-level positions, while $13 \%(n=32)$ had management roles. Seventy-five percent $(n=259)$ indicated that working in the industry positively influenced their decision about 
future work in hospitality. Three percent $(n=12)$ said work experience had a negative influence while $10 \%(n=35)$ were unsure of the impact.

Post-graduation plans. Eighty-seven percent $(n=299)$ of students indicated that they were definitely intending, or more than likely, planning to work in the hospitality industry after graduation. Nine percent $(n=32)$ were unsure about entering the industry while $4 \%(n=14)$ indicated that it was unlikely or definitely not their plan to enter the industry after graduation. Of those who indicated that they would not work in the industry $(n=44), 46 \%(n=20)$ reported that working in the industry was a major factor in their decision not to seek hospitality employment while $16 \%(n=7)$ have never worked in the industry.

Table 12 indicates the position students expected to obtain after graduation. Thirty-six percent $(n=119)$ expected a manager-in-training position and 56\% $(n=187)$ expected a manager role. Table 13 indicates how prepared the students felt for a managerial role after graduation. 
Table 12

Position Expected After Graduation

\begin{tabular}{lcc}
\hline & Percentage & Number of Students \\
\hline Frontline & $15 \%$ & 49 \\
Supervisor & $13 \%$ & 43 \\
Manager in Training & $36 \%$ & 119 \\
Assistant Manager & $11 \%$ & 36 \\
Department Manager & $6 \%$ & 20 \\
General Manager & $4 \%$ & 12 \\
Other & $15 \%$ & 51 \\
\hline Note. Position expected by position rank order: low to high positions $(n=330)$.
\end{tabular}

Table 13

Perceived Readiness

Perceived Readiness Role $(n=330) \quad$ Percentage $\quad$ Number of Students

$\begin{array}{lll}\text { Very Well Qualified } & 14 \% & 47\end{array}$

$\begin{array}{lll}\text { Well Qualified } & 22 \% & 71\end{array}$

$\begin{array}{lll}\text { Qualified } & 27 \% & 88\end{array}$

$\begin{array}{lll}\text { Somewhat Qualified } & 32 \% & 107\end{array}$

$\begin{array}{lll}\text { Not Qualified } & 5 \% & 17\end{array}$

Note. Perceived readiness for an Assistant Manager position at graduation. 
Table 14 depicts the salary expected at graduation. Fifty-five percent $(n=182)$ reported that their desired salary was obtainable at graduation while $33 \%(n=109)$ were unsure and $12 \%(n=39)$ did not think their desired salary was obtainable.

Table 14

Salary Expected at Graduation

\begin{tabular}{lcc}
\hline Expected Salary $(n=330)$ & Percentage & Number of Students \\
\hline Over $\$ 70,000$ & $1 \%$ & 4 \\
Between $\$ 60,001-\$ 70,000$ & $11 \%$ & 36 \\
Between $\$ 50,001-\$ 60,000$ & $17 \%$ & 56 \\
Between $\$ 40,001$ and $\$ 50,000$ & $24 \%$ & 102 \\
Between $\$ 30,001$ and $\$ 40,000$ & $31 \%$ & 54 \\
Less than $\$ 30,000$ & $16 \%$ & \\
\hline
\end{tabular}

\section{Parental Education and SES}

Figure 3 shows the level of education of the 350 students' mothers and fathers. In total, $15 \%(n=53)$ of mothers and fathers had no college experience. Twenty-three percent $(n=81)$ of students had parents with less than an Associate's degree. In contrast, $25 \%(n=86)$ of mothers and fathers both had a four-year degree or higher. Descriptively (per Figure 3), mothers' versus fathers' educations had relatively comparable numbers for four of the six educational categories. In contrast, there were incomparable numbers for two of the six categories, specifically for two-year college degree and graduate professional degree, but no consistency in these differences by gender. 


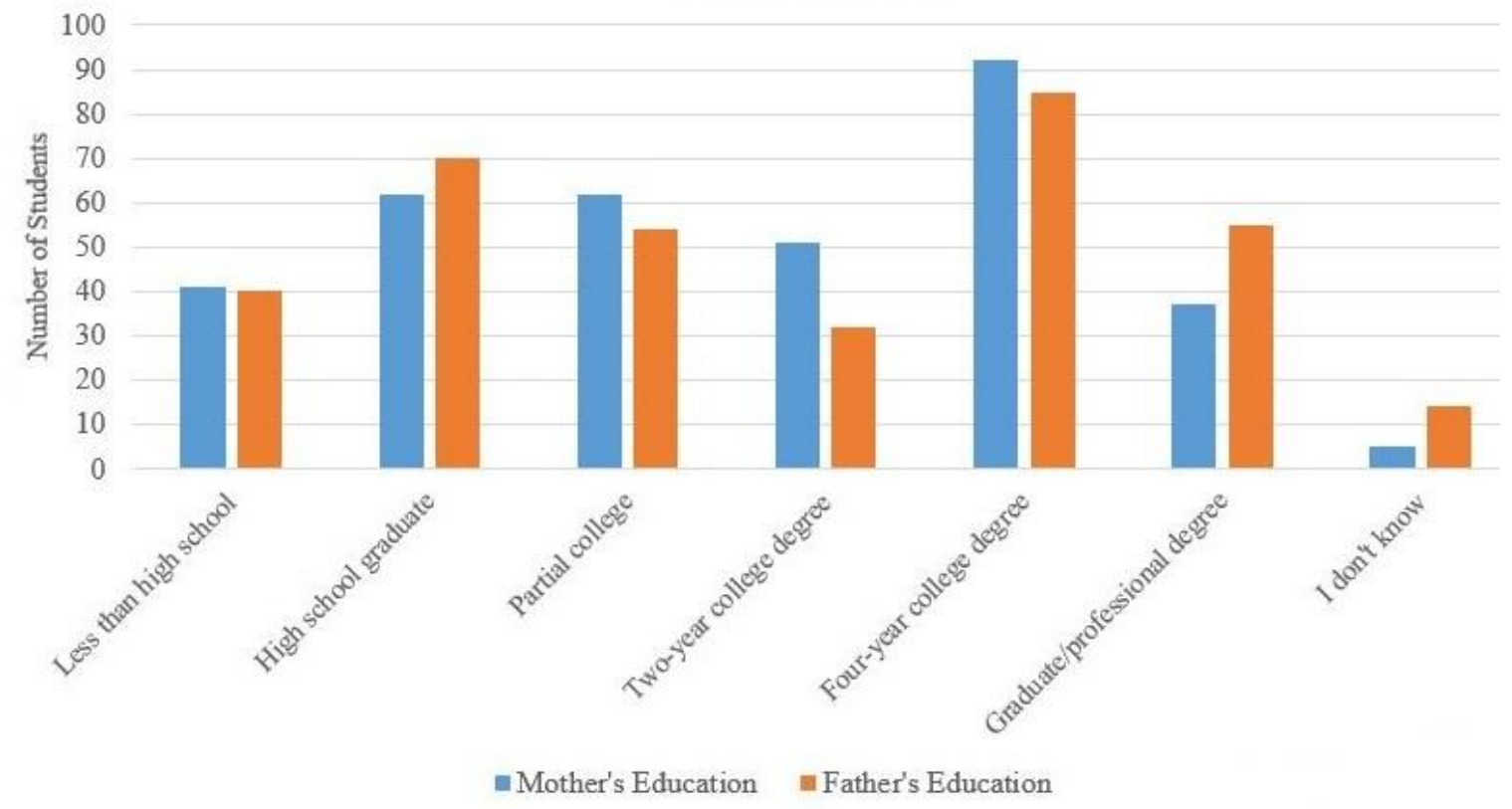

Figure 3. Highest level of education by parent.

Forty percent $(n=140)$ of the surveyed students indicated that they were eligible for the federally funded Pell grant. Twenty-eight percent $(n=98)$ indicated that they were not eligible, while $32 \%(n=112)$ were unsure of their eligibility.

\section{Prior Industry Exposure}

A total of 350 students completed the Prior Industry Exposure assessment. The assessment consisted of 29 activities within the hospitality industry. Among the 29, activities deemed to show extensive exposure were assigned two points and other activities were assigned one point in recognition of the expert content analysis described in Chapter 3. Thus, students' scores could be zero to 49. Table 14 displays the range, mean, median, and standard deviation for prior industry exposure scores, while Table 15 displays the number of students who participated in each activity. These data suggest that a majority $(>50 \%)$ of students participated in four activities, about one-third of students 
participated in three activities, while less than one-third of students participated in 22 activities.

Table 15

Prior Industry Exposure Scores

\begin{tabular}{llll}
\hline Range & Median & Mean & SD \\
\hline $1-30$ & 10 & 10.08 & $+/-5.8$ \\
\hline
\end{tabular}


Table 16

Student Prior Industry Exposure Participation by Activity

\begin{tabular}{|c|c|c|}
\hline Prior Industry Exposure $(n=350)$ & Percentage & Number of Students \\
\hline $\begin{array}{l}\text { 1. Stayed at a full-service hotel (Marriott, Westin, } \\
\text { Hilton, Hyatt, etc.) }\end{array}$ & $77 \%$ & 270 \\
\hline 2. *Dined at a steakhouse & $68 \%$ & 237 \\
\hline 3. Traveled internationally for a vacation & $66 \%$ & 232 \\
\hline 4. *Dined at a fine dining restaurant & $58 \%$ & 202 \\
\hline $\begin{array}{l}\text { 5. Worked in a restaurant before selecting hospitality as } \\
\text { a major (Entry level) }\end{array}$ & $40 \%$ & 141 \\
\hline 6. *Stayed at an all-inclusive resort & $35 \%$ & 124 \\
\hline 7. *Flew in business class & $34 \%$ & 120 \\
\hline 8. *Stayed at a five star or five diamond property & $29 \%$ & 100 \\
\hline 9. * Stayed overnight on a cruise ship & $28 \%$ & 97 \\
\hline 10. $*$ Traveled to $5+$ countries & $28 \%$ & 93 \\
\hline $\begin{array}{l}\text { 11. *Planned a school event for } 50+\text { people including } \\
\text { food and beverage }\end{array}$ & $26 \%$ & 90 \\
\hline $\begin{array}{l}\text { 12. Worked in the events industry before selecting } \\
\text { hospitality as a major (Entry level) }\end{array}$ & $16 \%$ & 57 \\
\hline $\begin{array}{l}\text { 13. *Worked in a restaurant before selecting hospitality } \\
\text { as a major (Supervisor/Manager) }\end{array}$ & $15 \%$ & 51 \\
\hline $\begin{array}{l}\text { 14. Worked in a hotel before selecting hospitality as a } \\
\text { major (Entry level) }\end{array}$ & $14 \%$ & 50 \\
\hline 15. *Flew in first class & $14 \%$ & 49 \\
\hline 16. *Dined at a Michelin Star restaurant & $14 \%$ & 48 \\
\hline $\begin{array}{l}\text { 17. Worked in the tourism industry before selecting } \\
\text { hospitality as a major (Entry level) }\end{array}$ & $13 \%$ & 44 \\
\hline $\begin{array}{l}\text { 18. Worked in banquets or catering before selecting } \\
\text { hospitality as a major (Entry level) }\end{array}$ & $13 \%$ & 44 \\
\hline $\begin{array}{l}\text { 19. *Family belonged to a private club (country club, } \\
\text { yacht club, city club) }\end{array}$ & $9 \%$ & 30 \\
\hline 20. Parent or guardian worked in a hotel & $7 \%$ & 23 \\
\hline 21. *Parent or guardian owned a restaurant & $6 \%$ & 21 \\
\hline $\begin{array}{l}\text { 22. *Worked in the events industry before selecting } \\
\text { hospitality as a major (Supervisor/Manager) }\end{array}$ & $5 \%$ & 16 \\
\hline
\end{tabular}


23. *Worked in banquets or catering before selecting $\quad 4 \%$ hospitality as a major (Supervisor/Manager)

24. Graduated from a hospitality program in high school $4 \% \quad 13$

25. Worked in the private club industry before selecting $3 \% \quad 11$ hospitality as a major (Entry level)

26. *Worked in the tourism industry before selecting $\quad 3 \% \quad 10$ hospitality as a major (Supervisor/Manager)

27. *Worked in a hotel before selecting hospitality as a $3 \% \quad 9$ major (Supervisor/Manager)

28. *Parent or guardian owned a hotel $1 \%$

29. *Worked in the private club industry before $\quad 1 \%$ selecting hospitality as a major (Supervisor/Manager)

Note: * indicates "extensive exposure" activity.

\section{Industry Attitudes}

In total, 330 students completed the industry attitudes assessment. Table 17 displays the range, mean, median, and standard deviation of the scores.

Table 17

Industry Attitudes Scores

\begin{tabular}{lccc}
\hline Range & Mean & Median & SD \\
\hline $77-130$ & 99.8 & 106 & $+/-26.6$
\end{tabular}

Note. The cumulative scores for the industry attitudes assessment. SD = Standard Deviation.

The mean score for the cumulative industry attitude scale was 99.7 and a median score of 106. On a per question basis, Table 18 displays the range, mean, median, and standard deviation. 
Table 18

Individual Question Assessment Scores

\begin{tabular}{lccc}
\hline Range & Mean & Median & SD \\
\hline $1-4$ & 2.8 & 2.9 & $+/-0.98$
\end{tabular}

Note. The per question bases scores for the industry attitudes assessment. SD $=$ Standard Deviation.

Since the scale was amended (per Chapter 3), a direct comparison to other studies was not possible. In general, these results suggest a positive overall attitude regarding the hospitality industry.

\section{Career Decision Self-Efficacy}

Three-hundred and fifteen students completed the CDSE-SF. Table 19 displays the range, mean, median, and standard deviation of the scores.

Table 19

Career Decision Self-Efficacy Scores

\begin{tabular}{lccc}
\hline Range & Mean & Median & SD \\
\hline $1.2-5.0$ & 3.81 & 3.88 & $+/-.69$
\end{tabular}

Note. $\mathrm{SD}=$ Standard Deviation

The mean score of a 3.81 indicated that the majority of students were confident and comfortable with the career decision-making skillset. For comparison purposes, Hsieh and Huang's (2014) study of 336 Taiwanese undergraduate students resulted in a CDSESF mean score of 3.49 with a standard deviation of .47 . 


\section{Inferential Statistics}

Research question 1. Research question one was, "How does socioeconomic status affect HTM students' industry attitudes, career goals, and career decision self-efficacy"?

Socioeconomic status and industry attitudes. There was one statistically significant result in the analysis of socioeconomic status and industry attitudes. A linear regression analysis found that mother's education was statistically significant to industry attitudes, $\mathrm{X}^{2}(6)=12.81, p=0.04$. Contrastively, father's education was not related to industry attitudes. Follow-up t-test comparisons comparing high SES $(M=100.58, S D=26.14)$ to low SES $(M=96.50, S D=29.64)$ demonstrated no statistically significant difference; $\mathrm{t}(168.09)=0.967, p=0.334$. Similarly, when SES was only defined as "Pell eligible" a t-test also found no statistically significant difference in industry attitudes, $\mathrm{t}(215)=-0.320, p=0.749$.

Socioeconomic status and career goals. There was one statistically significant result in the analysis of socioeconomic status and career goals. A Chi-Square analysis revealed that father's education was significantly related to career goals, $\mathrm{X}^{2}(36)=54.34, p=$ 0.0025. In contrast, the Chi-Square analysis revealed that mother's education did not influence career goals, nor did Pell grant eligibility respectively, $X^{2}(36)=33.413, p=$ $0.592 ; X^{2}(12)=11.347, p=0.499$.

Socioeconomic status and career decision self-efficacy. A linear regression analysis revealed that Pell eligibility was related to CDSE scores, $\mathrm{R}^{2}=0.29, \mathrm{~F}(314)=0.98, p=$ 0.022, but neither mother's education nor father's education was related to CDSE scores. 
A t-test confirmed no differences between students with high versus low SES on CDSE scores, $\mathrm{t}(148.36)=0.625, p=0.532$.

Post hoc analysis of the SES definition. Additionally, a post-hoc analysis via a linear regression between industry attitudes and CDSE scores found a statistically significant relationship. However, the $\mathrm{R}^{2}$ was low, perhaps due to the fact that categorical variables were converted into continuous variables, $\mathrm{R}^{2}=0.205, \mathrm{~F}(313)=80.98, p<.01$. As well, a post hoc analysis using a relative ratio format investigated this paper's definition of SES. Specifically, the results suggested that Pell eligibility yielded a slightly higher proportional difference than parent's education on both industry attitudes and career goals. Results are indicated in Tables 20, 21, 22 and 23. Although an interpretation here is limited, this could suggest that future studies should focus more on Pell eligibility instead of the combination of Pell eligibility and parental education.

Table 20

Pell Eligible: Industry Attitudes vs. Parents' Education

\begin{tabular}{lll}
\hline \multicolumn{1}{c}{ Parents' Education } & \multicolumn{2}{c}{ Industry Attitudes } \\
\hline & High IA & Low IA \\
High & 17 & 3 \\
Low & 74 & 14 \\
\hline
\end{tabular}

Note. Using relative ratio. Relative Ratio $=1.011$. Meaning 11 more people, out of 1,000, in the high group (4+ year degrees) that the low group will have a higher industry attitude. 
Table 21

Parents' High Education: Industry Attitudes vs. Pell Eligibility

\begin{tabular}{lll}
\hline Pell Eligibility & \multicolumn{2}{c}{ Industry Attitudes } \\
\hline & High Industry Attitudes & Low Industry Attitudes \\
Yes & 37 & 3 \\
No & 36 & 3 \\
\hline Note. Using relative ratio. Relative Ratio = 0.921. Meaning 79 more people, out of 1,000, \\
in not Pell eligible group than the eligible group will have high career goals.
\end{tabular}

Table 22

Pell Eligibility: Career Goals vs. Parents' Education

\begin{tabular}{|c|c|c|}
\hline Parents' Education & Caree & \\
\hline & High Career Goals & Low Career Goals \\
\hline High & 11 & 6 \\
\hline Low & 44 & 23 \\
\hline
\end{tabular}

Table 23

Parents' High Education: Career Goals vs. Pell Eligibility

\begin{tabular}{lll}
\hline \multicolumn{2}{c}{ Pell Eligibility } & \multicolumn{2}{c}{ Career Goal } \\
\hline \multicolumn{3}{l}{ High Career Goals } \\
Yes & 11 & Low Career Goals \\
No & 22 & 14 \\
\hline Note. Using relative ratio. Relative Ratio = 1.059. Meaning 59 more people, out of 1,000, \\
from the Pell eligible group, than the not eligible group, will have high career goals.
\end{tabular}


Research question 2. Research question two was, "How does prior industry exposure affect HTM students' industry attitudes, career goals, and career decision self-efficacy?"

Prior industry exposure and industry attitudes. There was one statistically significant result in the analysis of prior industry exposure and industry attitudes. A linear regression analysis found that students' prior industry exposure score was statistically significant to their industry attitude scores, $\mathrm{R}^{2}=0.017, \mathrm{~F}(1)=5.46, p=0.02$.

Prior industry exposure and career goals. A logistic regression analysis found that the relationship between prior industry exposure and career goals was not statistically significant, $\mathrm{X}^{2}(1)=0.05, p=0.825$. In contrast, a post-hoc logistic regression that examined students with only responses classified as high career goals and prior industry exposure found a statistically significant relationship, $\mathrm{X}^{2}(1)=0.121, p=0.001$. Findings revealed that with every additional unit of prior industry exposure, career goals increased by $12.97 \%$. In contrast, a similar post-hoc logistic regression analysis with only low career goals, found no statically significant relationship to prior industry exposure, $\mathrm{X}^{2}$ $(311)=1.54, p=0.215$. However, within lowest career goals group, there was a nonsignificant trend for higher career goals to be associated with higher prior industry exposure scores.

Prior industry exposure and career decision self-efficacy. A linear regression analysis revealed that prior industry exposure was statistically significant to students' CDSE, $\mathrm{R}^{2}(0.030), \mathrm{F}(1)=9.886, p=0.001$. However, these data indicated a very small $\mathrm{R}^{2}$ statistic (.03). Therefore, the most accurate interpretation of this result was that with 
each unit of increased prior industry exposure, there was a 0.02 increase in CDSE scores. This suggests a low to modest relationship between prior industry exposure and CDSE.

Research question 3. Research question three was, "How does year in school affect HTM students' industry attitudes, career goals, and career decision self-efficacy?"

Year in school and industry attitudes, career goals, and career decision self-efficacy. Proportion analyses combined with a series of chi-square analyses revealed that year in school was independent (not statistically significant) to industry attitudes, career goals, and career decision self-efficacy. An additional analysis that included prior industry exposure was also found to be independent to year in school. This means that students' year in school was not related to how they answered the survey questions. A post analysis via repeated correlation matrices based on year in school suggested some high positive correlations, although not statistically significant. Examples included, juniors had a high positive correlation between career goals with industry attitudes and prior industry exposure and seniors between career goals and CDSE. This indicates that there were observable changes in the correlation of the dependent variables between junior and senior year. Tables 24, 25, 26, and 27 display the correlations. For comparison purposes, Table 28 provides a correlation coefficient value and the suggested interpretations of the Pearson Correlations as provided by Al-Samman (2012). 
Table 24

Freshman Findings: Dependent Variables' Pearson Correlations

\begin{tabular}{|c|c|c|c|c|}
\hline & $\begin{array}{l}\text { Industry } \\
\text { Attitudes }\end{array}$ & Career Goals & $\begin{array}{l}\text { Career } \\
\text { Decision Self- } \\
\text { Efficacy }\end{array}$ & $\begin{array}{l}\text { Prior Industry } \\
\text { Exposure }\end{array}$ \\
\hline $\begin{array}{l}\text { Industry } \\
\text { Attitudes }\end{array}$ & & .100 & .225 & .504 \\
\hline Career Goals & & & .145 & .279 \\
\hline $\begin{array}{l}\text { Career } \\
\text { Decision Self- } \\
\text { Efficacy }\end{array}$ & & & & .146 \\
\hline $\begin{array}{l}\text { Prior Industry } \\
\text { Exposure }\end{array}$ & & & & \\
\hline
\end{tabular}

Table 25

Sophomore Findings: Dependent Variables' Pearson Correlations

\begin{tabular}{|c|c|c|c|c|}
\hline & $\begin{array}{l}\text { Industry } \\
\text { Attitudes }\end{array}$ & Career Goals & $\begin{array}{c}\text { Career } \\
\text { Decision Self- } \\
\text { Efficacy } \\
\end{array}$ & $\begin{array}{c}\text { Prior Industry } \\
\text { Exposure }\end{array}$ \\
\hline $\begin{array}{l}\text { Industry } \\
\text { Attitudes }\end{array}$ & & .364 & .530 & .429 \\
\hline Career Goals & & & .093 & $.036^{*}$ \\
\hline $\begin{array}{l}\text { Career } \\
\text { Decision Self- } \\
\text { Efficacy }\end{array}$ & & & & .683 \\
\hline $\begin{array}{l}\text { Prior Industry } \\
\text { Exposure }\end{array}$ & & & & \\
\hline
\end{tabular}

Note. *indicates statistically significant 
Table 26

Junior Findings: Dependent Variables' Pearson Correlations

\begin{tabular}{|c|c|c|c|c|}
\hline & $\begin{array}{l}\text { Industry } \\
\text { Attitudes }\end{array}$ & Career Goals & $\begin{array}{l}\text { Career } \\
\text { Decision Self- } \\
\text { Efficacy }\end{array}$ & $\begin{array}{l}\text { Prior Industry } \\
\text { Exposure }\end{array}$ \\
\hline $\begin{array}{l}\text { Industry } \\
\text { Attitudes }\end{array}$ & & .861 & .554 & .600 \\
\hline Career Goals & & & .288 & .939 \\
\hline $\begin{array}{l}\text { Career } \\
\text { Decision Self- } \\
\text { Efficacy }\end{array}$ & & & & .514 \\
\hline $\begin{array}{l}\text { Prior Industry } \\
\text { Exposure }\end{array}$ & & & & \\
\hline
\end{tabular}

Table 27

Senior Findings Dependent Variables' Pearson Correlations

\begin{tabular}{|c|c|c|c|c|}
\hline & $\begin{array}{l}\text { Industry } \\
\text { Attitudes }\end{array}$ & Career Goals & $\begin{array}{l}\text { Career } \\
\text { Decision Self- } \\
\text { Efficacy }\end{array}$ & $\begin{array}{l}\text { Prior Industry } \\
\text { Exposure }\end{array}$ \\
\hline $\begin{array}{l}\text { Industry } \\
\text { Attitudes }\end{array}$ & & .397 & .142 & .213 \\
\hline Career Goals & & & .904 & .184 \\
\hline $\begin{array}{l}\text { Career } \\
\text { Decision Self- } \\
\text { Efficacy }\end{array}$ & & & & .081 \\
\hline $\begin{array}{l}\text { Prior Industry } \\
\text { Exposure }\end{array}$ & & & & \\
\hline
\end{tabular}


Table 28

Correlation Indication

\begin{tabular}{ll}
\hline Correlation Coefficient $(\mathrm{r})$ Value & Indication \\
\hline \pm 0.8 to \pm 1.0 & High correlation \\
\pm 0.6 to \pm 0.79 & Moderately high correlation \\
\pm 0.4 to \pm 0.59 & Moderate correlation \\
\pm 0.2 to \pm 0.39 & Low correlation \\
\pm 0.1 to \pm 0.19 & Negligible correlation
\end{tabular}

Note. Correlation Indication. Adapted from "The Influence of Transparency on the Leaders' Behaviors" by E. N. Al-Samman (2012), p.31.

Research question 4. Research question four was, "What is the relationship between HTM students' demographic characteristics and their industry attitudes, career goals, and career decision self-efficacy?"

Demographics characteristics related to industry attitudes. A linear regression investigating industry attitudes and the independent variables of: age, race, emphasis, time worked in the industry, level of employment, SES, year in school, likeliness to enter the industry after graduation, and prior industry exposure, resulted in no statistically significant findings. It was concluded that all variables were independent of each other.

Additional post-hoc analysis related to demographic variables. Because of the aforementioned result, a series of post-hoc analyses were performed to identify if any of 
the demographic variables had statistically significant relationships with industry attitudes, career goals, and career decision self-efficacy.

Race, industry attitude, and Pell grant eligibility. After myriad analyses, an interesting finding emerged regarding race. First, a one-way ANOVA found statistically significant results for race (White, Asian American, and Mexican/Mexican American) based on industry attitudes $[\mathrm{F}(2)=6.676, p=0.001]$, CDSE scores $[\mathrm{F}(2)=7.621, p<$ $.001]$, and prior industry exposure $[\mathrm{F}(2)=12.185, p<.001]$. However, follow-up t-test comparisons did not yield statistically significant differences among the three groups except when each race was more narrowly subdivided by Pell grant eligibility (or ineligibility). Here, t-test comparisons found statistically significant differences only in the Pell eligible versus Pell ineligible Asian American group members for industry attitudes [t $(651.69)=2.367, p=0.018]$, CDSE scores [t $(641.18)=2.202, p=0.027]$, and prior industry experience $[\mathrm{t}(645.78)=2.749, p=0.006]$. These data suggest that Pell grant eligibility could be a factor among this study's Asian American participants. Interestingly, comparable follow-up t-tests for White and Mexican/Mexican American students did not yield comparable statistically significant results. Descriptively however, Mexican/Mexican American students reported the lowest levels of prior industry exposure.

Parental education. After multiple analyses, a second interesting finding emerged which found, via a linear regression, that fathers with a graduate or professional degree were statistically significant and had an influence on students' prior industry exposure, $\mathrm{R}^{2}$ $=0.395, \mathrm{~F}(221)=2.355, p<0.001$. Similarly, fathers with less than a high school degree 
demonstrated a negative relationship to students' prior industry exposure, $\mathrm{R}^{2}=0.395, \mathrm{~F}$ $(221)=2.355, p=0.033$. 


\section{Chapter 5. Conclusions}

\section{Introduction}

This study explored how students' SES, prior industry exposure, year in school, and demographics affect industry attitudes, career goals, and career decision self-efficacy of undergraduates studying HTM. This chapter will summarize and interpret the study's findings, compare results to existing literature, make recommendations for future studies, and discuss limitations.

\section{Summary of the Study}

As previously stated, the hospitality industry experiences significant turnover. As discussed in the literature review, many scholars found it necessary to investigate students' studying HTM and how they feel about the industry. The purpose of this study was to explore how students' SES, prior industry exposure, year in school, and various demographics affect industry attitudes, career goals, and CDSE. Results from this study will impact universities in multiple ways to enhance student success via assessing and developing curricular and programming innovations, career services, and pre-professional HTM activities. This study's results also provide insights for hospitality industry professionals interested in developing more effective recruitment and retention strategies.

Research question 1. Research question one was, "How does socioeconomic status affect HTM students' industry attitudes, career goals, and career decision self-efficacy?"

Findings and past literature. Using the study's initial definition, there was no significant relationship between SES and industry attitudes, career goals, and CDSE; however, elements of the definition yielded statistically significant results for all the 
dependent variables. For example, industry attitudes were statistically significant to mother's education level, while career goals were statistically significant to father's education level. These findings contradict Mohd Zahari's (2004) study which found that parental background was not significant to students' industry attitudes and might have occurred due to differing definitions of parental background. For example, the present study used parental education and Pell grant eligibility, while Mohd Zahari (2004) used a combination of parent education, family income, and parent occupation.

Another contradictory result was that students' Pell grant eligibility was statistically significant to CDSE. This finding contradicts Hsieh and Huang's (2014) conclusion that family SES, which used a combination of parental education and parental occupation, was positively correlated with student career self-efficacy. The present study found that only Pell grant eligibility was statistically significant to CDSE. The conflicting results could also be due to the definitions that were used. For example, the present study did not account for parental occupation, while Hsieh and Huang (2004) did not account for income or family earnings, which is used to determine Pell grant eligibility. Additionally, Hsieh and Huang (2004) focused only on Taiwanese students who were not studying hospitality, in marked contrast to the American-educated students surveyed in this study. Interestingly, this study's post hoc analyses found a relationship among Asian American students when SES was more narrowly defined (i.e., Pell grant eligibility only).

In contrast, this study's SES scores were consistent with an earlier report from Walpole (2003). Walpole noted that students from a lower SES typically spent more time at work compared to their peers from a higher SES. Walpole (2003) indicated that the 
burden of more time spent at work was an additional stressor to students from a lower SES. The present study's results are in agreement with Walpole (2003) and found that students from a low SES were working more hours than students from a high SES.

Implications. There are several potential implications to this research. It is suggested that HTM programs use these findings as a model. If programs have a student body that is mostly Pell grant eligible, then perhaps they will need to develop curricula and professional development programing that is geared to increasing students' CDSE. This is especially true if programs have a high concentration of Asian American students who are Pell eligible. Results from the current study indicated that Asian American students' industry attitudes, CDSE, and prior industry exposure varied based on SES.

It should also be noted that $32 \%(n=112)$ of students were unsure of their Pell eligibility. This is a noteworthy (and surprising) percentage of students. Future studies might ask students about the amount of financial aid they receive, which might be clearer than recalling the name of a federally funded grant. As well, future studies might explore why HTM students are unsure about their own Pell grant eligibility and whether this result is consistent with undergraduates in related fields of study. If HTM students are an anomaly, it might suggest a factor related to their awareness of educational supports.

Research question 2. Research question two was, "How does prior industry exposure affect HTM students' industry attitudes, career goals, and career decision self-efficacy"?

Findings and past literature. A linear regression found a statistically significant relationship between prior industry exposure and industry attitudes and career goals. This result was expected and lends support to Lent et al. (2002) and the SCCT, which 
indicated that exposure leads to an increase in industry self-efficacy and career goals. In other words, the greater the exposure students have to the industry, the more they will start thinking of different career opportunities within the industry. If universities want to increase students' positive industry attitudes or career goals, they should focus on increasing students' industry exposure.

A linear regression also found that prior industry exposure was statistically significant to CDSE. This is consistent with Lent and Brown's (1996) finding of a relationship between exposure level to self-efficacy and career decision self-efficacy. For example, if students do not experience the breadth of the hospitality industry, and thus not develop self-efficacy within the industry, then they are likely to feel less efficacious regarding a career in the industry. Results indicated that prior industry exposure had a triatic relationship with industry attitudes and CDSE. As students' prior industry exposure increased, so did their industry attitudes, and CDSE.

Interestingly, a linear regression did not find that SES was statistically significant to prior industry exposure. In fact, there was no statistically significant finding for prior industry exposure when comparing students from a low or high SES, when SES was more generally defined. This contrasts with Lent et al. (2002) and the SCCT, which indicated that SES could limit the amount of exposure to an industry, which further affects students' career goals and career self-efficacy. In contrast, a narrower definition of SES (i.e., Pell-grant eligibility only) suggested a relationship for Asian American students only. Similarly, another interesting finding, though not unexpected (per Hsieh and Huang, 2014), was the relationship between father's education level and prior 
industry exposure. This finding suggested a marked contrast among fathers with the highest versus the lowest education levels.

Implications. These findings suggest that university curricula should consider the merit of increasing students' prior industry exposure, especially since only a minority of surveyed students reported ample exposure to the HTM industry (per table 15) and varied prior hospitality experiences (per table 16). University programs should focus on creating opportunities so that their undergraduate students can participate in the "prior industry exposure" activities included in this study's tool. Doing so might foster deeper self-reflection by students about their industry attitudes, career goals, and CDSE. University programs cannot change students' prior industry exposure, parental education or Pell grant eligibility, but program leaders and faculty members can develop curricula and programing to increase prior industry exposure, in ways that lend themselves to foster positive industry attitudes, practical career goals, and purposeful self-efficacy. Programs with more Asian American students might find such activities especially useful given this study's contrastive results among Pell eligible and ineligible students. Similarly, programs with a larger number of Mexican/Mexican American students might also need to encourage helping these students increase the breadth and depth of their industry exposure. Additionally, future research could examine the short- and long-term effects of increased exposure opportunities.

Developing curriculum and programing to increase students' prior industry exposure could be seen as a high-impact learning practice. Kuh (2008) outlined 10 high-impact learning practices that led to increased student engagement and future student success. 
These 10 practices increased student retention rates and engagement (Kuh, 2008), key variables in student success efforts. Kuh (2008) recommends that every student have at least two of the 10 outlined practices before they graduate, and at least one should be within the first semester. High-impact practices that could incorporate industry exposure include: internships (gaining new industry work experience), field-based learning (visiting or touring industry establishments), and first year experiences (developing practical skills needed for the industry). An example of a possible first-year learning experience could be a "hospitality fellows" program. This program could focus on developing meaningful "prior industry exposure" activities that allow students to experience the industry outside of the classroom.

University programs can also develop opportunities that give students real life exposure to the industry across all courses. Such experiences could focus on embedding elements of the prior industry exposure tool into existing courses. Two examples that could be embedded into hospitality courses include, 1) a service management course learning about customer resolution and seeing it in practice at a front desk of a hotel, and 2) a food and beverage operations course where students visit different classifications of restaurants. This recommendation is consistent with Richardson (2009) who called for programs to give students an extensive overview of available careers and possible career paths within the industry. Chak-keung Wong and Jing Liu (2010) also recommended learning seminars and field trips which would further increase students' exposure to the industry. Additionally, many scholars agree that guest lecturers (with industry personnel) 
can aid students in developing realistic expectations of the industry (Chak-keung Wong \& Jing Liu, 2010; Chan, 2017).

Other significant findings. Although time in the industry did not yield a broad statistically significant finding, there was a notable descriptive difference among students who had more (five+ years; $M=12.32$ ) versus less (6 to 12 months; $M=9.52$ ) hospitality work experience. Furthermore, slightly higher prior industry exposure scores were observed among students who reported being likely to enter the industry after graduation (i.e., $M=10.20$ versus $M=8.82$ ), respectively. This finding could suggest that students' prior industry exposure made a difference in their opinions about whether they planned to stay in the industry after graduation. This finding should encourage programs and industry professionals to carefully consider how they can work together in developing meaningful and frequent opportunities and pathways for students. Increasing someone's industry exposure score, despite less prior work experience, could lead to higher levels of retention within the industry after graduation. Contrastively, programs might also focus on expanding the range of hospitality exposure for people with more industry experience concentrated in just one or two sectors of the industry. Both topics have face validity and future research could explore the efficacy of these activities.

Another descriptive finding worthy of discussion is students' career goals upon graduation compared to their prior industry exposure scores. Many students who indicated that they wanted to graduate and become a department manager, an unrealistic expectation for most graduates, had the lowest prior industry exposure score $(M=8.65)$. Students who indicated they wanted to become a frontline employee, a realistic but low 
career goal, had a lesser prior industry exposure score $(M=10.49)$ than those who indicated a manager in training position $(M=11.67)$, a higher career goal. These results could suggest that those who do not have much exposure to the industry have inflated career goals that do not match the actual industry. Perhaps, with more industry exposure during their HTM courses, students could better understand that a manager in training position is a likely best fit after graduation.

Research question 3. Research question three was, "How does year in school affect HTM students' industry attitudes, career goals, and career decision self-efficacy”?

Findings and past literature. Year in school, collectively, had no statistically significant relationship with industry attitudes, career goals, or CDSE, although these results must be cautiously interpreted since this study had fewer freshmen/sophomores than juniors/seniors. In general, this finding is inconsistent with prior research. Chan (2017) found that freshmen had the strongest motivation to work in the industry and that sophomores experienced a decrease in industry perception likely due to required work experience. Blomme et al. (2009) found that first year students had higher industry perspectives about career opportunities which lowered once they acquired experience. Blomme et al. (2009) also noted that compared to seniors, more first-year students wanted to enter the industry after graduation. The inconsistencies in the findings could be due to the number of freshmen $(n=23)$ that were in this study compared to the number of 
freshmen in Blomme et al., (2009) $(n=224)$ and Chan (2017) $(n=118)$. The lack of freshmen in the present study makes it difficult to make valid comparison interpretations.

In this study, the profile for juniors and seniors was notably different. Juniors experienced moderate to high positive correlations (albeit not statistically significant) between all of the independent variables, with high positive correlations between career goals and industry attitudes and career goals and prior industry exposure. This could be due to the fact that some juniors might be focused on transferring into the school or major and maybe initially learning the curriculum (like freshmen and sophomores) and obtaining internships. Senior students experienced a high positive correlation (also not statistically significant) between career goals and CDSE only. These contrasting findings suggest observable changes in the correlation of these variables between junior and senior year. It is possible that senior year students, more focused on graduating, have prioritized advocating for themselves when it comes to obtaining employment. A high positive correlation could also indicate that the hospitality programs are preparing students to have realistic expectations of careers in the industry upon graduation.

As previously mentioned, seniors demonstrated a high correlation between career goals and CDSE. This implies that industry recruiters might emphasize career planning and career goals for potential new hires. In fact, Blomme, Van Rheede, and Tromp (2009) recommended that recruiters should be involved in the educational process to aid in developing realistic expectations before they transition from student to employee. Career planning should then continue through the first years of employment. Perhaps industry recruiters need to create a career goal training platform that allows 
potential recruits and new hires to see what career opportunities could be possible in the next 5 to 10 years. Chan (2007) also noted the importance of career promotions/opportunities and career talks for students. Since the current study was conducted in April, it could be possible that seniors, who were most likely graduating in the next month, could have been looking for career opportunities that demonstrated a clear career path.

Results also found that juniors' prior industry exposure was related to career goals. At many hospitality programs, a large percentage of juniors are transfer students. For example, both Lee, Lee, and Dobson (2018) and Chuang and Dellmann-Jenkins (2010) found $30 \%$ of hospitality students were transfer students. Practically, it would be helpful for programs to collect data on incoming students regarding their career goals and prior industry exposure. This would give programs a meaningful baseline of the incoming class and students' results could shape upcoming professional development curricula and activities.

Research question 4. Research question four was, "How do various demographics affect HTM students' industry attitudes, career goals, and career decision self-efficacy"?

Findings and past literature. A linear regression found no statistically significant relationships among: SES, year in school, race, time worked in the industry, level of employment, age, likelihood to enter the industry after graduation, and prior industry exposure. Provided below is a breakdown of the demographic variables collected.

Sex. This study's students appear consistent with the gender proportions typical to hospitality programs. Seventy-nine percent of respondents were female. Although having 
more females than males is typical for hospitality programs, $79 \%$ is larger than previous studies. For example, past studies reported the percentage of female students as 54\% (Richardson, 2008), 58\% (Mohd Zahari, 2004), and 70\% (Chung \& Chan, 2017). This finding, along with prior reports, indicates that hospitality, as a major, is still mainly comprised of female students. Although the current study did not compare female to male respondents, it is important to note the results of prior studies. Mohd Zarari (2004) found very few differences in industry attitudes between males and females, while Chuang et al., (2017) found little gender difference in CDSE responses. In contrast, Chuang and Dellmann-Jenkins (2010) found that females showed a higher intent to enter the industry after graduation.

Race. The three most represented race/ethnicities in this study were White/NonLatino (32\%), Asian American (26\%), and Mexican American/Mexican (15\%). Representation of race/ethnicity could be unique to the western United States and might not represent all the hospitality programs in the country (i.e., external validity). However, there are no known national statistics regarding the race/ethnicity of all hospitality students in the United States.

Race was a broad and statistically significant factor that influenced students' industry attitudes, CDSE, and prior industry exposure and appeared to interact with Pell-eligibility for Asian American students. Moreover, descriptive data further suggested differences among the races on each of the dependent variables. It is important for HTM programs to consider these findings and to also consider the impact of race on student success initiatives (i.e., programmatic activities and course offerings) with an eye towards 
enhancing students' attitudes, self-efficacy, and industry exposure. For example, according to the present study, if a program has a large Asian American population of students, they may have lower industry attitudes and CDSE compared to other races, especially if they are Pell grant eligible. Additionally, if a program has more Mexican/Mexican American students, these students may have lower prior industry exposure scores and have less overall exposure to the industry. By being familiar with student demographics, a program can strategically develop curricula designed to narrow the gap in student achievement.

Curriculum development based on a program's student population is considered a student-centered approach (Fay, 1988). McLean and Gibbs (2010) outlined tips on the implications of learner-centered curriculum. For example, they recommended helping students feel actively engaged and represented in the curriculum, as well as involved and empowered. The flexibility of learner-centered curriculum allows students to explore personal areas of interest and feel nurtured and supported (McLean \& Gibbs, 2010). This support and sense of belonging combined with a learner-centered curriculum might aid in program retention and industry retention after graduation.

Age. Descriptively, surveyed students' ages ranged from 18 to 55 years old with most students between the ages of 18 to 24 . The students had a mean age of 23 , indicating that many students are adult-learners and not traditional four-year college students right after high school graduation. While age was not a statistically significant factor in this study, it is useful for programs to understand that the age of their students could influence program activities and the curriculum. For example, if a program learns that it has 
students who are older than traditional college students, professional development, career services, and the curriculum should focus on addressing these students' unique learning styles and needs.

Emphasis. Although emphasis area was not a statistically significant factor, descriptive data found that surveyed students were mostly interested in three areas and varied in their responses to industry attitudes and CDSE. For example, Food and Beverage Management students demonstrated the highest industry attitudes score $(M=$ $2.93 \& 105.63)$ while Hotel/Lodging Management demonstrated the lowest $(M=2.66 \&$ 95.98). In contrast, when exploring students' emphasis and CDSE, Event Management had the highest score $(M=3.96)$ while Travel/Tourism/Other had the lowest score $(M=$ 3.57). These findings suggest that emphasis might be practically related to both industry attitude and CDSE and this finding can help programs further understand their students based on their emphasis selection. For example, if the majority of students identified as Event Management, programs might focus their career services/ professional development in developing other factors instead of CDSE. Conversely, if the majority of students identified as Travel/Tourism/Other or Hotel/Lodging Management, programs might want to focus on developing students' CDSE and industry attitude scores. If programs understand what the majority of students already have based on their selected emphasis, then programs can focus on additional areas that are less intuitive to students.

Work experience. Seventy percent of the respondents had worked in the industry, which suggests that most hospitality students have work experience. Sixty-three percent had over two years of work experience in the industry, while one quarter of respondents 
were full-time employees and 58\% worked more than 20 hours per week in the industry. If $58 \%$ of students worked more than 20 hours a week in the industry and were taking classes, one can assume that they did not have much time for after school activities or professional development activities. These findings suggest that efforts to increase prior industry exposure, industry attitudes, and CDSE should be built into the curriculum (where they have a captive audience since students are expected to attend class) versus creating extracurricular activities. All students, not just those with more free time, should be able to benefit from targeted and deeper student success efforts.

Additionally, this study found that HTM students had varied degrees of prior work experience. Although not currently explored, it would be interesting to know whether degree of prior industry experience was associated with longer or shorter career retention. Implications for such a finding could include programs recruiting future students in different ways based on prior work experience and helping graduates understand potential career paths based on their prior skills. This might be accomplished via deeper partnerships between HTM programs and hospitality companies to recruit future employees in ways that are fine-tuned to students' prior experiences. Such partnerships will enable would-be employees and companies to consider the likely match between the students' skills, expectations, and career goals and a company's vision and mission.

Seventy-five percent of respondents indicated that work experience had a positive influence on overall perception of the industry. This finding is consistent with Chan (2017) and Chuang and Dellmann-Jenkins (2010). Eighty-seven percent indicated that they will definitely or more than likely work in the industry after graduation with $13 \%$ 
unsure or will not enter the industry upon graduation. This $87 \%$ of students who indicated their likelihood of entering the industry after graduation is slightly higher than previous findings of 82\% (Chuang, et al., 2007), 73\% (Chan, 2017), 68\% (Lu \& Adler, 2008), and $27 \%$ (Richardson, 2007). This indicates that currently, as a percentage, more hospitality students are interested in graduating and working in the industry. This is an optimistic finding for industry recruiters.

Career goals. When examining students' career goals after graduation, 37\% expected a manager in training role, while $15 \%$ expected a frontline position, $13 \%$ expected a supervisor role, and $11 \%$ expected an assistant manager position. Thirty-seven percent reported feeling somewhat or not qualified to take an assistant manager position upon graduation. Considering that the majority of students who participated in the survey were seniors $(n=173)$, many of them did not feel as if the curriculum prepared them for an assistant manager role. This finding should be concerning to hospitality programs. Future research could include undertaking studies to identify why graduating students do not feel ready for an assistant manager position and how this compares to related disciplines and student-to-employee transition processes.

\section{Limitations}

There were four limitations of this study that must be considered relative to survey design, survey processes, participants, and data analysis. There was one limitation related to survey design. Many survey questions were posed in a fixed response format, which may have limited the reliability of students' responses. Additionally, fixed responses required participants to conform their answers to the given options. Finally, fixed 
responses, compared to open-ended questions, did not give respondents a chance to explain their answers (Krosnick, 1999).

There were two limitations related to the survey process. First, the survey was disseminated through hospitality programs via an online Qualtrics link. It is possible, though unlikely, that the link could have been sent to individuals who were not the target population. This limitation was mitigated through qualifying questions at the beginning of the survey. Second, the prior industry exposure tool asked students to recall activities they participated in from the ages of 8-18. Some students may have found it difficult to recall activities from such a young age. This tool also included categories of restaurants and hotels that lowerclassmen might not have understood due to being in their first years in the hospitality curriculum. Such a problem exists throughout the HTM student literature when lowerclassmen were studied.

The purposive sample of participants might also be regarded as a limitation in this study. First, the survey was only applicable to students in a four-year Bachelor's degree program. This study excluded hospitality students who were obtaining a two-year Associate's degree. Similarly, the survey data included responses from students from eleven universities ranging from 5 to 146 student responses. These universities were located primarily on the western coast of the United States, thus not including students' opinions from other geographic areas. The restricted geographical area of the respondents could limit the external validity of the results and suggest a demographic bias (Krosnick, 1999). These participants were also limited based on the definition of SES. In this study, the variables included mother's education, father's education, and Pell grant eligibility. 
Pell eligibility did not take into account when a student without an income had other financial supports (family, friends, etc.) who could provide resources not otherwise reported on FASA (Free Application for Federal Student Aid). Similarly, undocumented students are unable to receive Pell grants, making their financial status unknown. Pell eligibility also does not apply to students who are utilizing the G.I. Bill. Additionally, perhaps asking for mother's and father's actual occupations in addition to their education might have been another useful approach for estimating SES (Hsieh \& Huang, 2014).

The positionality of the researcher could have been a limitation. The researcher was a part-time lecturer at two universities within a large public university system. Past, present, and future students may have been research participants. Based on this, students might have participated in the voluntary survey in order to please the researcher (i.e., subject bias) despite the use of third parties who distributed the survey.

Limitations were also present in the data analysis. The questions pertaining to career goals, which were borrowed from a previous researcher, did not prove as useful to this study as planned. Thus, this study's career goal data were not as robust as the data for the other dependent variables.

\section{Recommendations for Future Research}

Based on the statistically significant findings between prior industry exposure, industry attitudes, and CDSE, more research is needed to investigate the interaction of these variables within the critical pre-professional developmental period of HTM majors. Prior industry exposure is a concept that has been minimally explored in the extant literature, and yet the current findings suggest it may have a robust influence on students' 
industry attitudes and CDSE. It would also be beneficial to compare hospitality students' prior industry exposure scores to students of other majors to fully understand the developmental trajectory experienced by the larger population of undergraduate students. Perhaps, for example, there are cognitive, affective, and behavioral patterns associated with young adulthood that also impact choice of college major and career. Moreover, perhaps students chose to enter hospitality because they had greater exposure to the industry as a child, although this does not solely account for exposure's impact. Hospitality students could be a unique subset in terms of cumulative scores and participation in specific activities. For example, if students in hospitality chose the major based on their prior experiences within the industry, it might be the case that they would have higher prior industry exposure scores or particular industry exposure experiences that influenced them differently than students from another major. This is an interesting concept and should be further explored in future research.

Affective responses could also be further studied. Affective responses are emotions or feelings that affect the overall attitude toward a subject or object (Verplanken, Hofstee, \& Janssen, 1998). This could include whether experiences were good or bad and favorable or unfavorable. Depending on the individual's emotions or feelings during an activity, the overall perspective or attitude could change. Future studies might investigate affective responses to the prior industry exposure activities and how such responses influenced the overall perception of the hospitality industry.

A longitudinal study that investigates seniors' industry attitudes, CDSE, prior industry exposure and intent to enter the industry is also recommended. A follow-up 
study could be conducted four years after graduation to see if individuals stayed within the hospitality industry and why. Questions would explore how their life experience was or was not related to their pre-professional industry attitudes and prior industry exposure. Analyses can be conducted to compare the group who continued to work in the hospitality industry with the group who decided to pursue other careers. A critical element within such a longitudinal study could specifically explore seniors entering the hospitality industry after graduation and their reasons for choosing certain positions or companies. This would provide insight about whether potential career pathways were important in selecting a certain company.

Additional future studies could focus solely on the attitudes, perceptions, career goals, and CDSE of international students. That research would provide insight as to whether international students have similar characteristics to the mostly American students in this study. A separate study on international students could also take into account the cultural values and norms regarding recreation and leisure activities.

A qualitative analysis of which prior industry exposure activities were selected based on students' demographics is also recommended. This research would explore certain activities and see whether they are more utilized based on students' demographic characteristics. Programs could use that information to generalize what parts of the industry their students might not have exposure to based on their particular demographics.

It is also recommended that future research explore variations of first generation college students. Although this was originally not a research question, this became an 
interesting factor when examining the data and needs further exploration. A preliminary review suggests the data showed that first generation college students had comparable industry attitudes (2.94) and slightly higher CDSE (3.93) scores compared to Pell eligible students $(2.93,3.77$ respectively). The true definition of a first generation college student is if neither parent attended college level courses (Choy, 2001). In this study, 21\% were considered first generation college students but $38 \%$ had parents who did not obtain a post-secondary degree but might have taken some college level courses. Toutkoushian, Stollberg, and Slaton (2018), noted that how a researcher defines first generation status mattered when measuring a deficit between first generation students and traditional students. Additionally, Shroder (2019) found an inequity in employment status at graduation between first generation college students (which included students whose parents might have taken college level classes but never graduated) and traditional students. This suggests that there may be further iterations of what qualifies as a first generation college student, and their industry attitudes, career goals, and CDSE should be further explored for differences.

\section{Conclusion}

This study explored how students' SES, prior industry exposure, year in school and demographics affected their industry attitudes, career goals, and CDSE. This study was important because the hospitality industry has a long history of high turnover rates. Understanding hospitality students' opinions and how they affect industry attitudes, career goals, and CDSE will aid programs in developing or modifying curriculum. It will also help with professional development programing in the hope of reducing industry 
turnover and developing the right talent for the industry. Major findings included that Pell grant eligibility was significant to students' attitudes, and CDSE scores. Prior industry exposure was statistically significant to industry attitudes and CDSE scores, and race combined with Pell grant eligibility, was statistically significant to students who identify as being Asian American. Additionally, students' overall demographics such as race, emphasis, time in the industry, position, and age were significant to industry attitudes, CDSE, prior industry exposure, and intent to enter the industry. Recommendations for students included focusing on obtaining industry exposure as outlined by the prior industry exposure tool as a method for increasing industry attitudes and CDSE. Programs should also focus on adding elements of the prior industry exposure tool to the curriculum and/or professional development programing as a strategy for increasing students' industry attitudes and CDSE. Programs should also consider how student demographics affect the curriculum and professional development programing. There should be conscious efforts to design and implement programing that benefits the majority of students based on their industry exposure and knowledge. Programs can also use the results of this study to recruit industry professionals who are more likely to stay in the industry after graduation.

Findings also indicated that recruiters should understand the demographics of programs and how they relate to students' prior industry exposure, industry attitudes, and CDSE scores. This information can aid in targeted recruitment strategies. Additionally, recruiters can focus on career planning and development with seniors as a recruitment strategy and a tool in employee retention. 
In conclusion, the results of this study supported prior findings regarding hospitality students and offered new insights into their attitudes, opinions, career goals, and industry self-efficacy. This study also introduced a new concept, prior industry exposure, which should be explored as a factor in future research. 


\section{References}

Agrawal, A. W., Blumenberg, E. A., Abel, S., Pierce, G., \& Darrah, C. N. (2011). Getting around when you're just getting by: The travel behavior and transportation expenditures of low-income adults (No. CA-MTI-10-2806). San Jose, CA: Mineta Transportation Institute.

Ahmad, Z., Ismail, H., \& Anantharaman, R. N. (2015). To be or not to be: An investigation of accounting students' career intentions. Education + Training, 57(3), 360-376.

Akin Aksu, A., \& Deniz Köksal, C. (2005). Perceptions and attitudes of tourism students in Turkey. International Journal of Contemporary Hospitality Management, 17(5), 436-447.

Ali, S. R., McWhirter, E. H., \& Chronister, K. M. (2005). Self-efficacy and vocational outcome expectations for adolescents of lower socioeconomic status: A pilot study. Journal of Career Assessment, 13(1), 40-58.

Al-Samman, E. N. (2012). The influence of transparency on the leaders' behaviors (Master's thesis, Open University Malaysia, Kuala Lumpur, Malaysia). Retrieved from https://www.academia.edu/5547739/

American Educational Research Association, American Psychological Association, \& National Council on Measurement in Education. (2014). Standards for educational and psychological testing (Rev. ed.). Washington, DC: American Educational Research Association.

American Psychological Association. (n.d.). Socioeconomic status. Retrieved from http://www.apa.org/topics/socioeconomic-status/

Amobi, T., \& Bahari, H. (2017, October). Hotels, restaurants, \& leisure. Standard \& Poor's Industry Surveys. Retrieved March 19, 2018 from NetAdvantage database.

Anderson, M. (2016). Who relies on public transit in the U.S. Pew Research Center. Retrieved June 17, 2019.

Arthur, N. (2014). Social justice and career guidance in the Age of Talent. International Journal for Educational and Vocational Guidance, 14(1), 47-60.

Bandura, A. (1977). Self-efficacy: Toward a unifying theory of behavioral change. Psychological Review, 84, 191-215.

Bandura, A. (1986). Social foundations of thought and action: A social cognitive theory. Englewood Cliffs, NJ: Prentice-Hall.

Barrows, C. W., \& Bosselman, R. H. (1999). Hospitality management education. Psychology Press. 
Betz, N. E., Klein, K. L., \& Taylor, K. M. (1996). Evaluation of a short form of the career decision-making self-efficacy scale. Journal of Career Assessment, 4(1), 47-57.

Betz, N. E., \& Taylor, K. M. (2012). Career decision self-efficacy scale: Manual and sampler set. EUA: Mind Garden.

Blomme, R., Van Rheede, A., \& Tromp, D. (2009). The hospitality industry: An attractive employer? An exploration of students' and industry workers' perceptions of hospitality as a career field. Journal of Hospitality \& Tourism Education, 21(2), 6-14.

Bogdan, R., \& Biklen, S. K. (1992). Qualitative research for education. Boston, MA: Allyn and Bacon.

Brymer, R. A. (2003). Hospitality \& tourism: An introduction to the industry. Dubuque, IA: Kendall Hunt.

Chak-keung Wong, S., \& Jing Liu, G. (2010). Will parental influences affect career choice? Evidence from hospitality and tourism management students in China. International Journal of Contemporary Hospitality Management, 22(1), 82-102.

Chan, M. C. (2017). Exploring how hospitality undergraduate students' perceptions and attitudes towards a career in the hospitality industry are affected by their work experience: A New Zealand quantitative study (Master's thesis, Auckland University of Technology, Auckland, New Zealand). Retrieved from https://openrepository.aut.ac.nz/handle/10292/10421

Chen, C. T., \& Chen, C. F. (2011). The influence of internship experiences on the behavioral intentions of college students in Taiwan. The Asia-Pacific Education Researcher, 20(1), 73-92.

Chen, T. L., \& Shen, C. C. (2012). Today's intern, tomorrow's practitioner?-The influence of internship programmes on students' career development in the hospitality industry. Journal of Hospitality, Leisure, Sport \& Tourism Education, 11(1), 29-40.

Choy, S. (2001). Students whose parents did not go to college: Postsecondary access, persistence, and attainment (Findings from the Condition of Education, 2001, no. 16). Washington, DC: National Center for Education Statistics, Office of Educational Research and Improvement, U.S. Department of Education.

Chuang, N. K., \& Dellmann-Jenkins, M. (2010). Career decision making and intention: A study of hospitality undergraduate students. Journal of Hospitality \& Tourism Research, 34(4), 512-530.

Chuang, N. K., Goh, B. K., Stout, B. L., \& Dellmann-Jenkins, M. (2007). Hospitality undergraduate students' career choices and factors influencing commitment to the profession. Journal of Hospitality \& Tourism Education, 19(4), 28-37.

Crites, J. O. (1978). Career maturity inventory. Monterey, CA: CTB/McGraw-Hill. 
Crompton, J. L. (1979). Motivations for pleasure vacation. Annals of Tourism Research, 6(4), 408-424.

Davidson, M. C., Timo, N., \& Wang, Y. (2010). How much does labour turnover cost? A case study of Australian four- and five-star hotels. International Journal of Contemporary Hospitality Management, 22(4), 451-466.

Dodds, R., \& Muchnick, H. (2008). Why do they come: Ryerson University student expectations for choosing a hospitality and tourism degree. Journal of Hospitality \& Tourism Education, 20(3), 17-19.

Exposure. (n.d.). In Cambridge Dictionary. Retrieved from https://dictionary.cambridge.org/us/dictionary/english/exposure

Fay, P. (1988). Open and student centred learning: Evangelism and heresy. Journal of Further and Higher Education, 12(1), 3-19.

Fickling, M. J., Lancaster, C., \& Neal, A. V. (2018). Social justice in career services: Perspectives of university career center directors. The Career Development Quarterly, 66(1), 64-76.

Formica, S. (1996). European hospitality and tourism education: Differences with the American model and future trends. International Journal of Hospitality Management, 15(4), 317-323.

Garriott, P. O., Flores, L. Y., \& Martens, M. P. (2013). Predicting the math/science career goals of low-income prospective first-generation college students. Journal of Counseling Psychology, 60(2), 200-209.

Georggi, N. L., \& Pendyala, R. M. (2001). An analysis of long-distance travel behavior of the elderly and the low-income (Working Paper). Retrieved from: https://www.researchgate.net/publication/266249266_Analysis_of_LongDistance_Travel_Behavior_of_the_Elderly_and_Low_Income

Getz, D. (1994). Students' work experiences, perceptions and attitudes towards careers in hospitality and tourism: A longitudinal case study in Spey Valley, Scotland. International Journal of Hospitality Management, 13(1), 25-37.

Ghiselli, R. F., La Lopa, J. M., \& Bai, B. (2001). Job satisfaction, life satisfaction, and turnover intent among food-service managers. Cornell Hotel and Restaurant Administration Quarterly, 42(2), 28-37.

Gibbons, M. M., \& Borders, L. D. (2010). Prospective first-generation college students: A social-cognitive perspective. The Career Development Quarterly, 58(3), 194-208.

Gitau, J. K. (2016). The determinants of career decision making of hospitality undergraduate students enrolled in universities within Nairobi metropolis, Kenya (Master's thesis, Kenyatta University, Nairobi, Kenya). Retrieved from https://irlibrary.ku.ac.ke/handle/123456789/14997 
Grobelna, A. (2017). The perception of job-related motivators when choosing a career in the tourism and hospitality industry-A comparative study between Polish and Spanish students. International Journal of Management and Economics, 53(2), 84-106.

Hackett, G., \& Betz, N. E. (1981). A self-efficacy approach to the career development of women. Journal of Vocational Behavior, 18(3), 326-339.

Hart, M., Kremin, J., \& Pasewark, W. R. (2016). Growing up: How audit internships affect students' commitment and long-term intentions to work in public accounting. Issues in Accounting Education, 32(2), 47-63.

Heal, G. M., \& Heal, G. M. (2008). When principles pay: Corporate social responsibility and the bottom line. New York, NY: Columbia Business School Publishing.

Hill, N. E., Ramirez, C., \& Dumka, L. E. (2003). Early adolescents' career aspirations: A qualitative study of perceived barriers and family support among low-income, ethnically diverse adolescents. Journal of Family Issues, 24(7), 934-959.

Hjalager, A. M. (2003). Global tourism careers? Opportunities and dilemmas facing higher education in tourism. Journal of Hospitality, Leisure, Sport \& Tourism Education, 2(2), 26-37.

Hooley, T., \& Sultana, R. G. (2016). Career guidance for social justice. Journal of the National Institute for Career Education and Counselling, 36, 2-11.

Hsieh, H. H., \& Huang, J. T. (2014). The effects of socioeconomic status and proactive personality on career decision self-efficacy. The Career Development Quarterly, 62(1), 29-43.

Kim, B. P., McCleary, K. W., \& Kaufman, T. (2010). The new generation in the industry: Hospitality/tourism students' career preferences, sources of influence and career choice factors. Journal of Hospitality \& Tourism Education, 22(3), 5-11.

Korir, J., \& Wafula, W. (2012). Factors that influence career choice of hospitality students in Moi University, Kenya. Journal of Education and Practice, 3(14), 83-90.

Krosnick, J. A. (1999). Survey research. Annual Review of Psychology, 50(1), 537-567.

Krumboltz, J. D., Mitchell, A. M., \& Jones, G. B. (1976). A social learning theory of career selection. The Counseling Psychologist, 6(1), 71-81.

Kuh, G. D. (2008). High-impact educational practices: What they are, who has access to them, and why they matter. Washington, DC: Association of American Colleges and Universities.

Kusluvan, S., \& Kusluvan, Z. (2000). Perceptions and attitudes of undergraduate tourism students towards working in the tourism industry in Turkey. Tourism Management, 21(3), 251-269. 
Kyriacou, C., \& Coulthard, M. (2000). Undergraduates' views of teaching as a career choice. Journal of Education for Teaching: International Research and Pedagogy, 26(2), 117-126.

Lam, T., \& Ching, L. (2007). An exploratory study of an internship program: The case of Hong Kong students. International Journal of Hospitality Management, 26(2), 336351.

Lee, M. J., Kim, S. S., \& Lo, A. (2008). Perceptions of hospitality and tourism students towards study motivations and preferences: A study of Hong Kong students. Journal of Hospitality, Leisure, Sport \& Tourism Education, 7(2), 45-58.

Lee, P. C., Lee, M. J., \& Dopson, L. R. (2019). Who influences college students' career choices? An empirical study of hospitality management students. Journal of Hospitality \& Tourism Education, 31(2), 74-86.

Lent, R. W., \& Brown, S. D. (1996). Social cognitive approach to career development: An overview. The Career Development Quarterly, 44(4), 310-321.

Lent, R. W., Brown, S. D., \& Hackett, G. (1994). Toward a unifying social cognitive theory of career and academic interest, choice, and performance. Journal of Vocational Behavior, 45(1), 79-122.

Lent, R. W., Brown, S. D., \& Hackett, G. (2000). Contextual supports and barriers to career choice: A social cognitive analysis. Journal of Counseling Psychology, 47(1), 36-49.

Lent, R. W., Brown, S. D., \& Hackett, G. (2002). Social cognitive career theory. Career Choice and Development, 4, 255-311.

Leppel, K., Williams, M. L., \& Waldauer, C. (2001). The impact of parental occupation and socioeconomic status on choice of college major. Journal of Family and Economic Issues, 22(4), 373-394.

Li, S. (2011). High turnover of college graduates in hotel industry in China and its countermeasures. 2011 International Conference on Management and Service Science, Wuhan, China, 1-4.

Line-level. (n.d.). In Alanpedia. Retrieved from http://www.alanpedia.com/travels_glossary_Hotel_operations_management/line_leve 1.html

Lu, T., \& Adler, H. (2009). Career goals and expectations of hospitality and tourism students in China. Journal of Teaching in Travel \& Tourism, 9(1-2), 63-80.

Ma, Y. (2009). Family socioeconomic status, parental involvement, and college major choices - Gender, race/ethnic, and nativity patterns. Sociological Perspectives, 52(2), 211-234. 
Mailhot, B. A., \& Feeney, S. L. (2017). Perceived parental involvement and academic achievement of college students: The mediating role of academic self-concept. North American Journal of Psychology, 19(3), 685-708.

Malgwi, C. A., Howe, M. A., \& Burnaby, P. A. (2005). Influences on students' choice of college major. Journal of Education for Business, 80(5), 275-282.

Marshall, C., \& Rossman, G. B. (2014). Designing qualitative research. Thousand Oaks, CA: Sage Publications.

Mcilveen, P., Everton, B., \& Clarke, J. (2005). University career service and social justice. Australian Journal of Career Development, 14(2), 63-71.

McLean, M., \& Gibbs, T. (2010). Twelve tips to designing and implementing a learnercentred curriculum: Prevention is better than cure. Medical Teacher, 32(3), 225-230.

Meyers, T. W. (2016). The relationship between socioeconomic status (SES) and the National Council Licensure Examination for Registered Nurses: Comparing SES indicators in mediated and moderated logistic regression (Doctoral dissertation, Kent State University, Kent, OH). Retrieved from https://etd.ohiolink.edu/

Mohd Zahari, M. S. (2004). A study of factors moderating Malaysian hospitality students selection of tertiary education institutions, programme and subsequent career intentions (Doctoral dissertation, Lincoln University, Canterbury, New Zealand). Retrieved from https://researcharchive.lincoln.ac.nz/handle/10182/1577

National Research Council. (2001). Knowing what students know: The science and design of educational assessment. Washington, DC: National Academies Press.

O'Brien, K. M. (2001). The legacy of Parsons: Career counselors and vocational psychologists as agents of social change. The Career Development Quarterly, 50(1), 66-76.

O'Mahony, G. B., McWilliams, A. M., \& Whitelaw, P. A. (2001). Why students choose a hospitality-degree program An Australian case study. The Cornell Hotel and Restaurant Administration Quarterly, 42(1), 92-96.

Peek, L., \& Fothergill, A. (2009). Using focus groups: Lessons from studying daycare centers, 9/11, and Hurricane Katrina. Qualitative Research, 9(1), 31-59.

Peerapatdit, N. (2004). The impact of selected socio-demographic, travel-related and psychographic variables on travel expenditures (Master's thesis, University of Central Florida, Orlando, FL). Retrieved from https://stars.library.ucf.edu/etd/222/

Qiu, S., Dooley, L., \& Palkar, T. (2017). What factors influence the career choice of hotel management major students in Guangzhou? Independent Journal of Management \& Production, 8(3), 1092-1115. 
Qualtrics (2018, May 3). Privacy Statement. Retrieved from https://www.qualtrics.com/privacy-statement/

Qualtrics (2018, July 13). Security Statement. Retrieved from https://www.qualtrics.com/security-statement/

Quinn, K., \& Buzzetto-Hollywood, N. (2019). Faculty and student perceptions of the importance of management skills in the hospitality industry. Interdisciplinary Journal of e-Skills and Lifelong Learning, 15, 21-42.

Raque-Bogdan, T. L., \& Lucas, M. S. (2016). Career aspirations and the first generation student: Unraveling the layers with social cognitive career theory. Journal of College Student Development, 57(3), 248-262.

Richardson, S. (2008). Undergraduate tourism and hospitality students attitudes toward a career in the industry: A preliminary investigation. Journal of Teaching in Travel \& Tourism, 8(1), 23-46.

Richardson, S. (2009). Undergraduates' perceptions of tourism and hospitality as a career choice. International Journal of Hospitality Management, 28(3), 382-388.

Richardson, S., \& Butler, G. (2012). Attitudes of Malaysian tourism and hospitality students towards a career in the industry. Asia Pacific Journal of Tourism Research, $17(3), 262-276$.

Richardson, S., \& Thomas, N. J. (2012). Utilising generation Y: United States hospitality and tourism students' perceptions of careers in the industry. Journal of Hospitality and Tourism Management, 19(1), 102-114.

Self, T. T., Gordon, S., \& Ghosh, A. (2020). Increasing management retention: The mediating role of organizational embeddedness on coworker support and turnover intention. International Journal of Hospitality \& Tourism Administration, 1-19.

Shroder, L. M. (2019). Job placement rates among first-generation hospitality students. Journal of Hospitality \& Tourism Education, 31(4), 256-260.

Stamps Jr, S. M., \& Stamps, M. B. (1985). Race, class and leisure activities of urban residents. Journal of Leisure Research, 17(1), 40-56.

Staniec, J. F. O. (2004). The effects of race, sex, and expected returns on the choice of college major. Eastern Economic Journal, 30(4), 549-562.

Stone, M. J., Padron, T. C., Wray, M. L., \& Olson, E. D. (2017). Career desires and expectations of event management students. Journal of Hospitality and Tourism Management, 32, 45-53. 
Struyven, K., \& Vanthournout, G. (2014). Teachers' exit decisions: An investigation into the reasons why newly qualified teachers fail to enter the teaching profession or why those who do enter do not continue teaching. Teaching and Teacher Education, 43, $37-45$.

Tall, M. (2019, June 11). What will it take to close hospitality's labor gap? Lodging Magazine. Retrieved from https://lodgingmagazine.com/what-will-it-take-to-closehospitalitys-labor-gap/

Taylor, K. M., \& Betz, N. E. (1983). Applications of self-efficacy theory to the understanding and treatment of career indecision. Journal of Vocational Behavior, 22(1), 63-81.

Toutkoushian, R. K., Stollberg, R. A., \& Slaton, K. A. (2018). Talking 'bout my generation: Defining "first-generation college students" in higher education research. Teachers College Record, 120(4), 1-38.

United States Bureau of Labor Statistics. (2010). BLS Spotlight on Statistics: Travel. Retrieved from https://www.bls.gov/spotlight/2010/travel/

United States Bureau of Labor Statistics. (2020, February). Industries at a glance: Leisure and hospitality. Retrieved from https://www.bls.gov/iag/tgs/iag70.htm

United States Department of Commerce, International Trade Administration. (2017). U.S. resident travel to international destinations increased eight percent in 2016. International Trade Administration/Industry \& Analysis.

United States Department of Education. (n.d.). Federal student aid. Federal Pell Grants. Retrieved from https://studentaid.ed.gov/sa/types/grants-scholarships/pell

United States Department of Education. (2015). Federal Pell Grant program. Retrieved from https://www2.ed.gov/programs/fpg/index.html?exp=0.

United States Department of Education. (n.d.). Fiscal Year 2018 budget. Retrieved from https://www2.ed.gov/about/overview/budget/budget18/summary/18summary.pdf

United States Department of Labor. (2017). Employment by major industry sector [Data file]. Retrieved from https://www.bls.gov/emp/ep_table_201.htm

United States Department of Labor. (2017). Output by major industry sector [Data file]. Retrieved from https://www.bls.gov/emp/ep_table_202.htm

Verplanken, B., Hofstee, G., \& Janssen, H. J. (1998). Accessibility of affective versus cognitive components of attitudes. European Journal of Social Psychology, 28(1), 23-35.

Walker, J. (2012). Introduction to hospitality (6th ed.). Upper Saddle River, NJ: Prentice Hall. 
Walpole, M. (2003). Socioeconomic status and college: How SES affects college experiences and outcomes. The Review of Higher Education, 27(1), 45-73.

Walsh, K., Chang, S., \& Tse, E. C. Y. (2015). Understanding students' intentions to join the hospitality industry: The role of emotional intelligence, service orientation, and industry satisfaction. Cornell Hospitality Quarterly, 56(4), 369-382.

Zajda, J., Majhanovich, S., \& Rust, V. (2007). Introduction: Education and social justice. International Review of Education, 52(1), 9-22. 
Appendix A. Survey Instrument

\section{The Role of Socioeconomic Status and Prior Industry Exposure on Influencing the Industry Attitudes,}

\section{Start of Block: Consent}

\section{Q30 REQUEST TO PARTICIPATE IN RESEARCH}

CONSENT NOTICE TITLE OF STUDY The role of socioeconomic status and prior industry exposure on influencing the industry attitudes, career goals, and career decision self-efficacy of undergraduate students studying hospitality and tourism management. NAME OF RESEARCHERS Laura Shroder, Graduate Student Dr. Paul Cascella, Supervising Professor San Jose State University, Connie L. Lurie College of Education PURPOSE You are being asked to participate in a research study investigating the role of socioeconomic status and prior industry exposure on influencing the industry attitudes, career goals, and career decision self-efficacy of undergraduates studying hospitality and tourism management. If you decide to participate in this study, you will be asked to complete a survey that asks about your socioeconomic status, how you experienced the hospitality industry as a child, and questions about your career decision-making process and career aspirations.

PROCEDURES Please read through the following information about your rights as a research participant. If you agree to take the survey, please select the agree button at the bottom of this page.

POTENTIAL RISKS There are no direct foreseeable risks anticipated other than those normally encountered in your daily life.

POTENTIAL BENEFITS Participants will not directly benefit from the study procedure. However, they may derive professional satisfaction knowing that they have contributed to the body of research about undergraduate hospitality majors.

COMPENSATION All students, regardless of their participation in the study, may choose to enter a drawing for the chance to win one of four \$25 Amazon gift cards. Students will be asked for their email address only if they wish to enter the drawing. E- 
mail addresses will only be used to conduct the lottery and contact students that will be awarded the gift card. Students will not be contacted for any additional reason. The lottery email addresses will be deleted once the lottery is conducted. Winners will be randomly selected using a computer software system (Excel: Random Selection Function). The chance of winning is no less than 1 in 250.

CONFIDENTIALITY Your information will be kept confidential. You will not be asked for your name or any information that could identify you. Organizations that may look at and/or copy research records to make sure that the study was done properly include: San Jose State University, Connie L. Lurie College of Education and San Jose State University, Institutional Review Board.

YOUR RIGHTS Your participation in this study is completely voluntary. You can refuse to participate in the entire study without any negative effect on your relations with your university. You also have the right to skip any question you do not wish to answer. QUESTIONS OR PROBLEMS If you have any questions about the study please contact Dr. Paul Cascella (Department of Ed.D. Leadership Program at San Jose State University) at paul.cascella@sjsu.edu or 408-924-3753. Complaints about the research may be presented to Dr. Arnold Danzig (Director of the Ed.D. Leadership Program at San Jose State University) at arnold.danzig@sjsu.edu or 408-924-3722. For questions about participants' rights or if you feel you have been harmed in any way by your participation in this study, please contact Dr. Pamela Stacks, Associate Vice President of the Office of Research, San Jose State University, at 408-924-2479.

AGREEMENT TO PARTICIPATE Please select from the choices below. By agreeing to participate in the study, it is implied that you have read and understand the above information. Please do not write any identifying information on the survey/questionnaire. Please keep a copy of this form for your own records.

I agree to participate in the research study (1)

I do not agree to participate in the research study (2)

Skip To: Q34 If REQUEST TO PARTICIPATE IN RESEARCH CONSENT NOTICE TITLE OF STUDY The role of socioeconomic status... = I do not agree to participate in the research study

Skip To: End of Block If REQUEST TO PARTICIPATE IN RESEARCH CONSENT NOTICE TITLE OF STUDY The role of socioeconomic status... = I agree to participate in the research study 
Q34 Would you like to be entered in a drawing for one of four \$25 Amazon gift cards?

$$
\begin{aligned}
& \text { Yes (1) } \\
& \text { No (2) }
\end{aligned}
$$

\section{Skip To: End of Survey If Would you like to be entered in a drawing for one of four $\$ 25$ Amazon gift} cards? $=$ No

\section{Display This Question:}

\section{If Would you like to be entered in a drawing for one of four $\$ 25$ Amazon gift cards? = Yes}

Q35 We will contact you via e-mail if you are chosen. Please input contact e-mail below:

\section{End of Block: Consent}

\section{Start of Block: Demographics}

Q32 Are you an undergraduate student who is 18 years or older, studying hospitality (tourism, events, food \& beverage) management at a four-year university?

\section{Yes (1) \\ No (2)}

Skip To: End of Survey If Are you an undergraduate student who is 18 years or older, studying hospitality (tourism, events,... = No

Q33 What university do you attend? 
Gender What is your gender?

\section{Female (1)}

Male (2)

Intersex (3)

Transwoman (4)

Transman (5)

Genderqueer (6)

Other (7)

I prefer not to say (8) 
Race What is your ethnicity?

\section{African American (1)}

American Indian or Alaskan Native (2)

Asian American (3)

Filipino (4)

Mexican American, Mexican (5)

Other Latino (6)

Pacific Islander (7)

White Non-Latino (8)

Mixed Race (9)

Unknown (10)

Prefer not to say (11)

Age What is your age? 
Year in School How would you describe your current status in school?

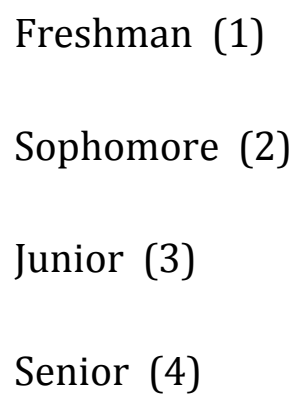

Intl Students Are you a domestic or international student?
Domestic (1)
International (2)
Prefer not to say (3)

Emphasis What is your main emphasis of interest in the hospitality industry?

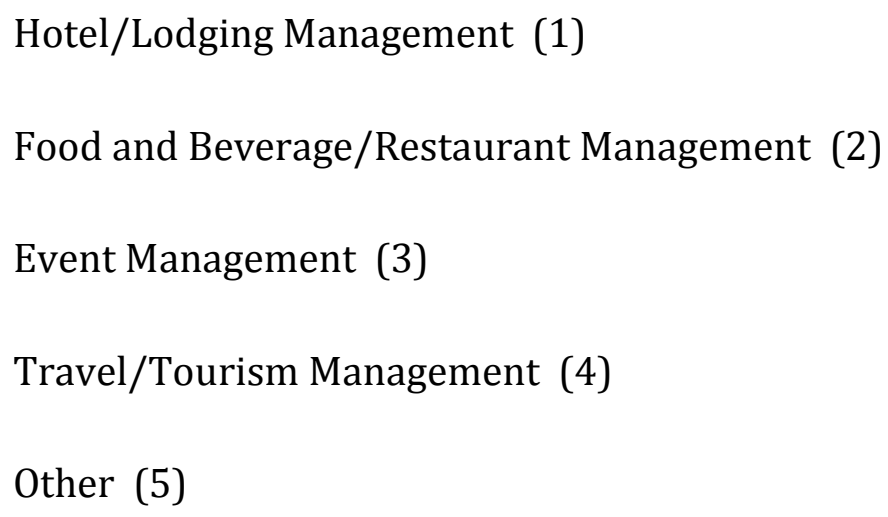


Edu Mom What is the highest level of education obtained by your mother?

Less than high school (1)

High school graduate (2)

Partial college (3)

Two-year college degree (4)

Four-year college degree (5)

Graduate/professional degree (6)

I don't know (7)

Edu Dad What is the highest level of education obtained by your father?

Less than high school (1)

High school graduate (2)

Partial college (3)

Two-year college degree (4)

Four-year college degree (5)

Graduate/professional degree (6)

I don't know (7) 
Pell eligibility Are you eligible to receive the federally funded Pell Grant?

\author{
Yes (1) \\ No (2) \\ I don't know (3)
}


Prior Exp Please check all activities that you experienced in the hospitality industry from the ages of 8-18 years old.

Stayed at a full service hotel (Marriott, Westin, Hilton, Hyatt, etc.) (1)

Worked in a hotel before selecting hospitality as a major (Entry level)

Parent or guardian worked in a hotel (3)

Parent or guardian owned a hotel (4)

Traveled internationally for a vacation (5)

Worked in the tourism industry before selecting hospitality as a major (Entry level) (6)

Graduated from a hospitality program in high school (7)

Worked in the private club industry before selecting hospitality as a major (Entry level) (8)

Worked in the events industry before selecting hospitality as a major (Entry level) (9)

Worked in a restaurant before selecting hospitality as a major (Entry level) (10)

Worked in banquets or catering before selecting hospitality as a major (Entry level) (11)

Worked in a hotel before selecting hospitality as a major (Supervisor/Manager) (12) 
Stayed at a five star or five diamond property (13)

Stayed at an all-inclusive resort (14)

Flew in first class (15)

Flew in business class (16)

Traveled to $5+$ countries (17)

Worked in the tourism industry before selecting hospitality as a major (Supervisor/Manager) (18)

Stayed overnight on a cruise ship (19)

Family belonged to a private club (country club, yacht club, city club) (20)

Worked in the private club industry before selecting hospitality as a major (Supervisor/Manager) (21)

Worked in the events industry before selecting hospitality as a major (Supervisor/Manager) (22)

Planned a school event for 50+ people including food and beverage (23)

Dined at a Michelin Star restaurant (24)

Dined at a fine dining restaurant (25)

Dined at a steakhouse (26) 
Parent or guardian owned a restaurant (27)

Worked in a restaurant before selecting hospitality as a major (Supervisor/Manager) (28)

Worked in banquets or catering before selecting hospitality as a major (Supervisor/Manager) (29)

Employed? Do you currently work in the Hospitality industry?

Yes (1)

No (2)

\section{End of Block: Demographics}

\section{Start of Block: Career Goals and Aspirations}

\section{Display This Question:}

If Do you currently work in the Hospitality industry? = Yes

Q13 How long have you worked in the industry?

Less than 6 months (1)

6 to 12 months (2)

12 months to 2 years (3)

2 years to 5 years (4)

5 years $+(5)$ 
Q14 On what basis are you currently employed in the hospitality industry?

Not currently working in the industry (1)

Casual (2)

Part-time (3)

Full-time (4)

Contract (5) 
Hours per week On average, how many hours per week do you work in the hospitality industry?

Not currently working in the industry (1)

$0-5(2)$

6-10 (3)

$11-15(4)$

$16-20(5)$

21-25 (6)

26-30 (7)

30-35 (8)

36-40 (9)

$41+(10)$

Display This Question:

If Do you currently work in the Hospitality industry? = Yes 
Level of emp In what type of position are/were you employed?
Frontline (1)
Supervisor (2)
Low level manager (3)
Middle manager (4)
Senior manager (5)
Other (6)

Q17 How has working in the industry influenced your decision about a future career in the industry?
Positively (1)
Negatively (2)
Neither (3)
Uncertain (4)

I have never worked in the industry (5) 
Work in HTM grad Are you likely to work in the hospitality industry in the first year after graduation?

Definitely (1)

More than Likely (2)

Undecided (3)

Unlikely (4)

Definitely Not (5)

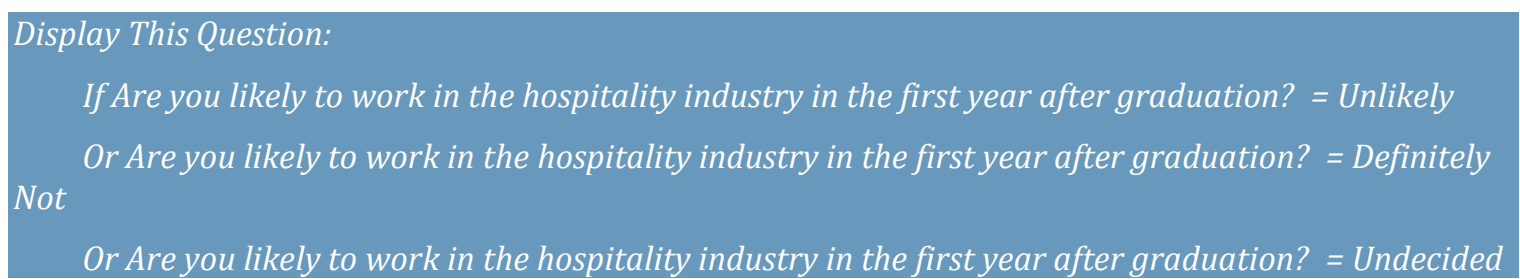

Q19 Has your experience working in the industry been the main factor in your uncertainty about pursuing a career in the industry?

Yes (1)

No (2)

I don't know (3)

I have never worked in the industry (4) 
Display This Question:

If Are you likely to work in the hospitality industry in the first year after graduation? = Definitely

Or Are you likely to work in the hospitality industry in the first year after graduation? = More than Likely

Q20 Has your experience working in the industry been the main factor in your decision to pursue a career in the industry?
Yes (1)
No (2)
I don't know (3)

Q21 What position do you expect to be offered when you graduate?

Frontline (1)

Supervisor (2)

Manager in Training (3)

Department Manager (4)

Assistant Manager (5)

General Manager (6)

Other (7) 
Q22 Which salary range do you expect to be offered for your first position after graduation?

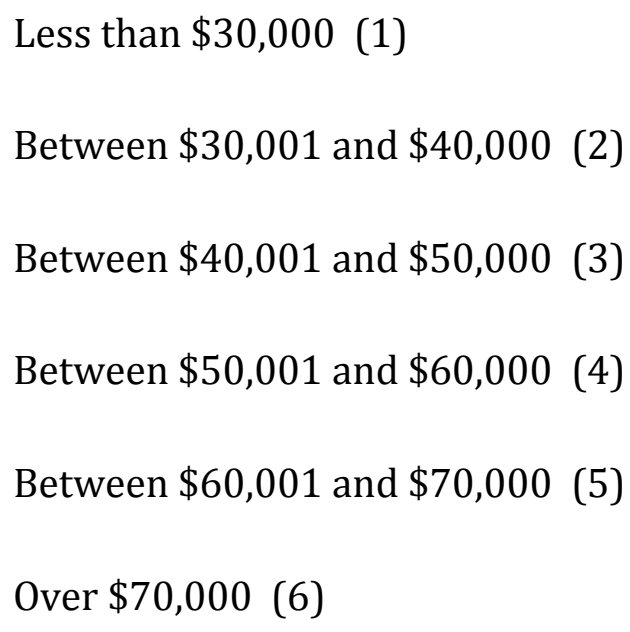

Q23 Do you believe you will be able to secure a position in the hospitality industry that will pay the salary you expect upon graduation?
Yes (1)
No (2)
Unsure (3) 
Q24 How qualified do you think you will be at graduation to assume an assistant manager position?

Not qualified (1)

Somewhat qualified (2)

Qualified (3)

Well qualified (4)

Very well qualified (5)

Industry Attitudes How much do you agree or disagree with each statement? 


\begin{tabular}{c|cc} 
& Strongly Agree & Agree (2) Disagree (3) \\
Disagree (4)
\end{tabular}




\begin{tabular}{|c|}
\hline $\begin{array}{l}\text { I talk to my } \\
\text { relatives and } \\
\text { friends with } \\
\text { pride about my } \\
\text { vocation in the } \\
\text { hospitality } \\
\text { industry (8) }\end{array}$ \\
\hline $\begin{array}{l}\text { My character } \\
\text { fits with } \\
\text { working in the } \\
\text { hospitality } \\
\text { industry (9) }\end{array}$ \\
\hline $\begin{array}{l}\text { I can use my } \\
\text { abilities and } \\
\text { skills in } \\
\text { hospitality jobs } \\
\text { (10) }\end{array}$ \\
\hline $\begin{array}{l}\text { I get pleasure } \\
\text { while working } \\
\text { in the } \\
\text { hospitality } \\
\text { industry (11) }\end{array}$ \\
\hline $\begin{array}{l}\text { I like to see } \\
\text { satisfied } \\
\text { customers when } \\
\text { I serve them } \\
\text { (12) }\end{array}$ \\
\hline $\begin{array}{l}\text { I think the pay } \\
\text { is low for most } \\
\text { jobs in the } \\
\text { hospitality } \\
\text { industry (13) }\end{array}$ \\
\hline $\begin{array}{l}\text { I think that the } \\
\text { pay for most } \\
\text { hospitality jobs } \\
\text { is not sufficient } \\
\text { to lead a } \\
\text { satisfactory life } \\
\text { (14) }\end{array}$ \\
\hline
\end{tabular}


Considering the long hours and workload, I find the pay low in the hospitality industry (15)

The level of fringe benefits (bonuses, leisure,

holidays, meals, etc.) is insufficient in the hospitality industry (16)

Promotion is based on merit in the hospitality industry (17)

Promotion opportunities are satisfactory in the hospitality industry (18)

Promotions are not handled fairly in the hospitality industry (19)

The opportunity of getting promoted to managerial positions is limited in the hospitality industry (20) 


Employees are
generally
uneducated in
the hospitality
industry (21)
I can make
friends easily
with people
working in the
hospitality
industry (22)
Most employees
are highly
motivated and
enthusiastic
about working
in the
hospitality
industry (23)
I think there are
good
relationships
among
employees in
the hospitality
industry (24)
Managers value
employees'
suggestions (25)
Managers do
not reward
employees who
are doing a
good job (26)




Managers
behave
respectfully
towards
employees in
the hospitality
industry (27)
Managers do
not put great
effort into
assuring that
employees are
satisfied with
their jobs (28)
In my opinion,
the
disadvantages
of working in
the hospitality
industry
outweigh the
advantages (29)
I am very happy
to have chosen
hospitality as a
vocation path
(30)
I would like to
work in the
hospitality
industry after
graduation ( 32$)$
industry after
graduation ( 31$)$
is definite that




It was a big
mistake to
choose
hospitality as a
career path (33)
I recommend a
job in the
hospitality
industry to my
friends and
relatives
because it is
very nice to be
part of this
industry (34)
I do not plan to
work in another
industry other
than the
hospitality
industry (35)
I see my
vocational
(professional)
future in the
hospitality
industry (36)

Q36 Copyright (C) 2012 by Nancy E. Betz and Karen M. Taylor. All rights reserved in all media. Published by Mind Garden, Inc. www.mindgarden.com

\section{End of Block: Career Goals and Aspirations}

Start of Block: Career Decision Self-Efficacy 
CDSE Final Question: For each statement below, please read carefully and indicate how much confidence you have that you could accomplish each of these tasks by marking your answer according to the following 5-point continuum.

\section{End of Block: Career Decision Self-Efficacy}

\section{Start of Block: Block 5}

Q30 Would you be interested in participating in future researh regarding the hospitality industry?

\section{Yes (1)}

No (2)

\section{Display This Question:}

If Would you be interested in participating in future researh regarding the hospitality industry? = Yes

Q31 Please enter your contact e-mail

Q28 Would you like to be entered in a drawing for one of four \$25 Amazon gift cards?

Yes (1)

No (2) 
Q29 We will contact you via e-mail if you have been chosen. Please enter your contact email: 


\section{Appendix B. Faculty Emails}

\section{Faculty Email:}

Dear Faculty,

My name is Laura Shroder and I am a doctoral student at San Jose State University. I am also a Lecturer at San Francisco State University and San Jose State University in the Hospitality and Tourism Management Departments. As a student, I am currently engaged in a doctoral dissertation research project investigating the role of socioeconomic status and prior industry exposure on industry attitudes, career goals, and career decision selfefficacy of undergraduates studying hospitality and tourism management.

I am hopeful that you will consider allowing your undergraduate hospitality students to participate in a brief (10 minute) survey. This study has been approved by the San Jose State University IRB. After completing the survey, students will have the option to enter a drawing for a chance to win one of four \$25 Amazon gift cards.

Survey distribution options include the following:

a. You can distribute the survey via the email below

b. I can distribute the survey if your program/course uses a listserv to communicate with students

c. Any additional way you prefer

I sincerely appreciate your consideration, and please let me know if I can answer any additional questions.

Best Regards,

Laura Shroder

\section{Student Email:}

Dear Hospitality Student,

My name is Laura Shroder and I am a doctoral student at San Jose State University. I am hoping that you will participate in my research study that is exploring variables affecting hospitality students' career goals and career decision making. Upon completion of the survey, you may choose to enter a drawing for the chance to win one of four $\mathbf{\$ 2 5}$

Amazon gift cards. E-mail addresses will only be used to conduct the lottery and contact students that will be awarded the gift cards. Your participation is completely voluntary and anonymous. 
Please go to this mobile- friendly link (Enter Survey) and answer questions about yourself, your hospitality experiences, and career goals.

Thank you for participating in this brief 10 minute study. (Enter Survey)

Laura Shroder 
Appendix C. Focus Group Guide and Student Profiles

\section{Student One: Lee}

How many times from the ages of 8-18 have you experienced the following activities?

\section{Lodging}

- 20 times- Stayed at a select service hotel (Courtyard Inn, Hilton Garden Inn, Holiday Inn Express, etc.)

- 5 times- Stayed at a full service hotel (Marriott, Westin, Hilton, Hyatt, etc.)

- 1 parent for 10 years- Parent or guardian worked in the lodging industry

Travel/Tourism

- 2 times- Traveled internationally for a vacation

- 2 times- Used a travel agency to plan trips

- 4 times- Visited a national park

- 4 times- Visited a museum

- 16 times- Attended a festival or fair

Events Industry

- 1- time Attended a charity ball or formal fundraiser

- 1 time- Planned a school event

Food and Beverage

How many times in an average year from 8-18 years old have you participated in the following activities?

- 4 times- Dined at a fine dining restaurant

- 1 time- Dined at a steakhouse

- 52 times- Dined at a select service restaurant

- 52 times- Dined at a fast food restaurant

- 104 times- Dined at a fast casual restaurant

- 104 times- Dined at a local family restaurant

_Limited

Moderate

Extensive

Notes:

\section{Student Two: Jasmine}


How many times from the ages of 8-18 have you experienced the following activities?

\section{Lodging}

- 10 times- Stayed at a select service hotel (Courtyard Inn, Hilton Garden Inn, Holiday Inn Express, etc.)

- 10 times- Stayed at a budget hotel (La Quinta, Motel 6, Travelodge, Super 8, etc.)

- 20 times- Stayed at a full service hotel (Marriott, Westin, Hilton, Hyatt, etc.)

- 5 times- Stayed at an all-inclusive resort

Travel/Tourism

- 10 times- Traveled internationally for a vacation

- 10 times- Visited a national park

- 10 times- Visited a museum

- 5 times- Attended a professional sports game

- 40 times- Attended a festival or fair

- 12 times- Attended a concert

- 1 time- Graduated from a hospitality program in high school

Private Club

- Family belonged to a private club (country club, yacht club, city club)

Events Industry

- 3 times- Attended a destination wedding

- 2 times- Attended a formal event or gala

- 1 times- Attended a charity ball or formal fundraiser

- 6 times- Planned a school event

Food and Beverage

How many times in an average year from 8-18 years old have you participated in the following activities?

- 1 time- Dined at a Michelin Star restaurant

- 6 times- Dined at a fine dining restaurant

- 5 times- Dined at a steakhouse

- 1 time- Dined at a celebrity chef restaurant

- 104 times- Dined at a select service restaurant

- 52 times- Dined at a fast food restaurant

- 50 times- Dined at a fast casual restaurant

- 14 times- Dined at a local family restaurant

- 1 year- Worked in a restaurant before selecting HTM as a major

__Limited

Moderate

Extensive

Notes:

\section{Student Three: Shay}


How many times from the ages of 8-18 have you experienced the following activities?

\section{Lodging}

- 12 times- Stayed at a select service hotel (Courtyard Inn, Hilton Garden Inn, Holiday Inn Express, etc.)

- 20 times- Stayed at a budget hotel (La Quinta, Motel 6, Travelodge, Super 8, etc.)

Travel/Tourism

- 4 times- Traveled internationally for a vacation

- 4 times- Visited a national park

- 10 times- Attended a festival or fair

- 4 times- Attended a concert

- Graduated from a hospitality program in high school

Private Club

- 2 times- Dined at a private club (country club, yacht club, city club)

\section{Events Industry}

- 2 times- Attended a destination wedding

- 2 times- Planned a school events

Food and Beverage

How many times in an average year from 8-18 years old have you participated in the following activities

- 52 times- Dined at a select service restaurant

- 52 times- Dined at a fast food restaurant

- 26 times- Dined at a fast casual restaurant

- 52 times- Dined at a local family restaurant

- 2 years- Worked in a restaurant before selecting HTM as a major

- 5 years- 1 Parent worked in a restaurant

Limited

Moderate

Extensive

Notes:

\section{Lodging Industry}

- Stayed at a select service hotel (Courtyard Inn, Hilton Garden Inn, Holiday Inn Express, etc.)

- $\quad$ Stayed at a budget hotel (La Quinta, Motel 6, Travelodge, Super 8, etc.)

- $\quad$ Stayed at a full service hotel (Marriott, Westin, Hilton, Hyatt, etc.) 
- Stayed at an all-inclusive resort

- Parent or guardian worked in a hotel

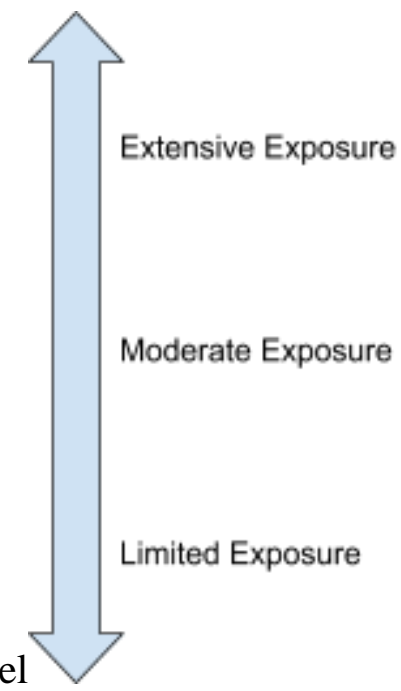

- Worked in a hotel before selecting HTM as a major

Travel and Tourism Industry

- Traveled internationally for a vacation

- Used a travel agency to plan trips

- Visited a national park

- Visited a museum

- Attended a professional sports game

- Attended a festival or fair

- Attended a concert

- Stayed overnight on a cruise ship

- Graduated from a hospitality program in high school

- Parent or guardian worked in the tourism industry

- Worked in the tourism industry before selecting HTM as a major

Private Club Industry

- Family belonged to a private club (country club, yacht club, city club)

- Dined at a private club (country club, yacht club, city club)

- Parent or guardian worked in the private club industry

- Worked in the private club industry before selecting HTM as a major

Events Industry

- Attended a destination wedding

- Attended a formal event or gala

- Attended a charity ball or formal fundraiser

- Planned a school event

- Parent or guardian worked in the events industry

- Worked in the events industry before selecting HTM as a major

Food and Beverage Industry

- Dined at a Michelin Star restaurant

- Dined at a fine dining restaurant

- Dined at a steakhouse 
- Dined at a celebrity chef restaurant

- Dined at a select service restaurant

- Dined at a fast food restaurant

- Dined at a fast casual restaurant

- Dined at a local family restaurant

- Parent or guardian worked in a restaurant

- Parent or guardian owned a restaurant

- Worked in a restaurant before selecting HTM as a major

Exposure to the Hospitality Industry- 7 Copies

The Social Cognitive Career Theory (SCCT) provides a framework for understanding how children develop Vocational Interests. Through repeated action and exposure to certain activities, a child can develop self-efficacy beliefs which could lead to certain career choices. Based on this theory, those who have in-depth exposure to the hospitality industry as children are more likely to believe that they can obtain a successful career within the industry.

\section{Focus Group}

Today we are here to discuss how students experience the hospitality industry prior to declaring it as their major. I'm attempting to develop an instrument that would describe students level of pre-industry exposure as "limited", "moderate" or "extensive". You are here to help me determine what qualifies a student into a category. Based on preliminary research with a content expert, I gathered that exposure is complex and relates to the type of activity, the frequency of the activity, and the amount of activities a student participates in.

I created three student profiles that I would like for you to discuss. This profile explains activities that a student participated in from the years 8-18. These activities are based on categories of the hospitality industry as described from John Walker's Introduction to Hospitality (6th Edition). I would like for you to to tell me how you would categorize the students exposure to the hospitality industry as either limited, moderate, or extensive and why?

Give all 3 profiles to focus group. 10 min talk per profile.

\section{Focus Group Questions:}

1. Based on the cumulative profile what category would you rank that student in?

2. Which characteristics had the most influence on that decision?

3. What specific items made you think that way?

4. Which one's did not have an impact in your decision?

5. If they participated in additional items what would elevate them to the next level?

6. Would your opinion change if the frequency of certain items went up or down? How much?

7. Are there any prominent activities that you feel are missing from the list?

\section{After Questions:}


1. Ask about graduating from an HTM HS- does that affect their exposure rate?

2. Working in the industry?

3. Guardian working in the industry?

\section{Probing Questions:}

"Tell me more about why?"

“Can we talk more about why you said what you said?" 


\title{
Appendix D. IRB Notice of Approval
}

\section{SJSU SAN OSE STATE $|=|=\mid$}

SAN JOSE STATE UNIVERSITY

\author{
HUMAN SUBJECTS INSTITUTIONAL REVIEW BOARD
}

IRB Notice of Approval

Date of Approval: 3/29/2019

Study Title: The Role of Socioeconomic Status and Prior Industry Exposure on Industry Attitudes, Career Goals, and Career Decision Self-Efficacy in Undergraduates Studying Hospitality and Tourism Management

Primary Investigator(s): Dr. Paul Cascella

Student(s): Laura Shroder

Other Team Members:

Funding Source: None

IRB Protocol Tracking Number: S19047

Type of Review

Q Exempt Registration: Category of approval $§ 46.104$ (d)(2ii)

$\square$ Expedited Review. Category of approval $\$ 46.110(a) 0$

$\square$ Full Review

$\square$ Modifications

$\square$ Continuing Review

Special Conditions

$\otimes$ Waiver of signed consent approved

Waiver of some or all elements of informed consent approved

Risk determination for device:

Other

Continuing Review

Q Is not required. Principal Investigator must file a status report with the Office of Research one year from the approval date on this notice to communicate whether the research activity is ongoing. Failure to file a status report will result in closure of the protocol and destruction of the protocol file after three years. 
Is required. An annual continuing review renewal application must be submitted to the Office of Research one year from the approval date on this notice. No human subjects research can occur after this date without continuing review and approval.

Approved by Dr. Pamela C. Stacks

Associate Vice President

Institutional Official

Office of Research

San Jose State University

IRB Contact

Alena Filip

Human Protections Analyst

408-924-2479

Alena.Filip@sisu.edu

Primary Investigator Responsibilities

- Any significant changes to the research must be submitted for review and approval prior to the implementation of the changes.

- Reports of unanticipated problems, injuries, or adverse events involving risks to participants must be submitted to the IRB within seven calendar days of the primary investigator's knowledge of the event.

- If the continuing review section of this notice indicates that continuing review is required, a request for continuing review must be submitted prior to the date the provided. 


\section{Appendix E. CDSE License}

\section{mind garden}

\section{www.mindgarden.com}

\section{To Whom It May Concern,}

The above-named person has made a license purchase from Mind Garden, Inc. and has permission to administer the following copyrighted instrument up to that quantity purchased:

\section{Career Decision Self-Efficacy Scale}

The three sample items only from this instrument as specified below may be included in your thesis or dissertation. Any other use must receive prior written permission from Mind Garden. The entire instrument may not be included or reproduced at any time in any other published material. Please understand that disclosing more than we have authorized will compromise the integrity and value of the test.

Citation of the instrument must include the applicable copyright statement listed below.

Sample Items:

How Much Confidence Do You Have That You Could:

Summarize the skills you have developed in the jobs you have held?

Select one major from a list of potential majors you are considering. Make a plan of your goals for the next five years.

Copyright (C) 2012 by Nancy E. Betz and Karen M. Taylor. All rights reserved in all media. Published by Mind Garden, Inc. www.mindgarden.com

Sincerely,

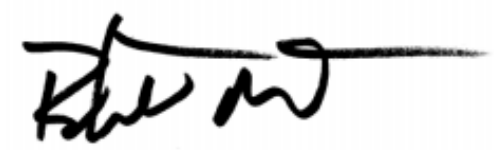

Robert Most

Mind Garden, Inc.

www.mindgarden.com 